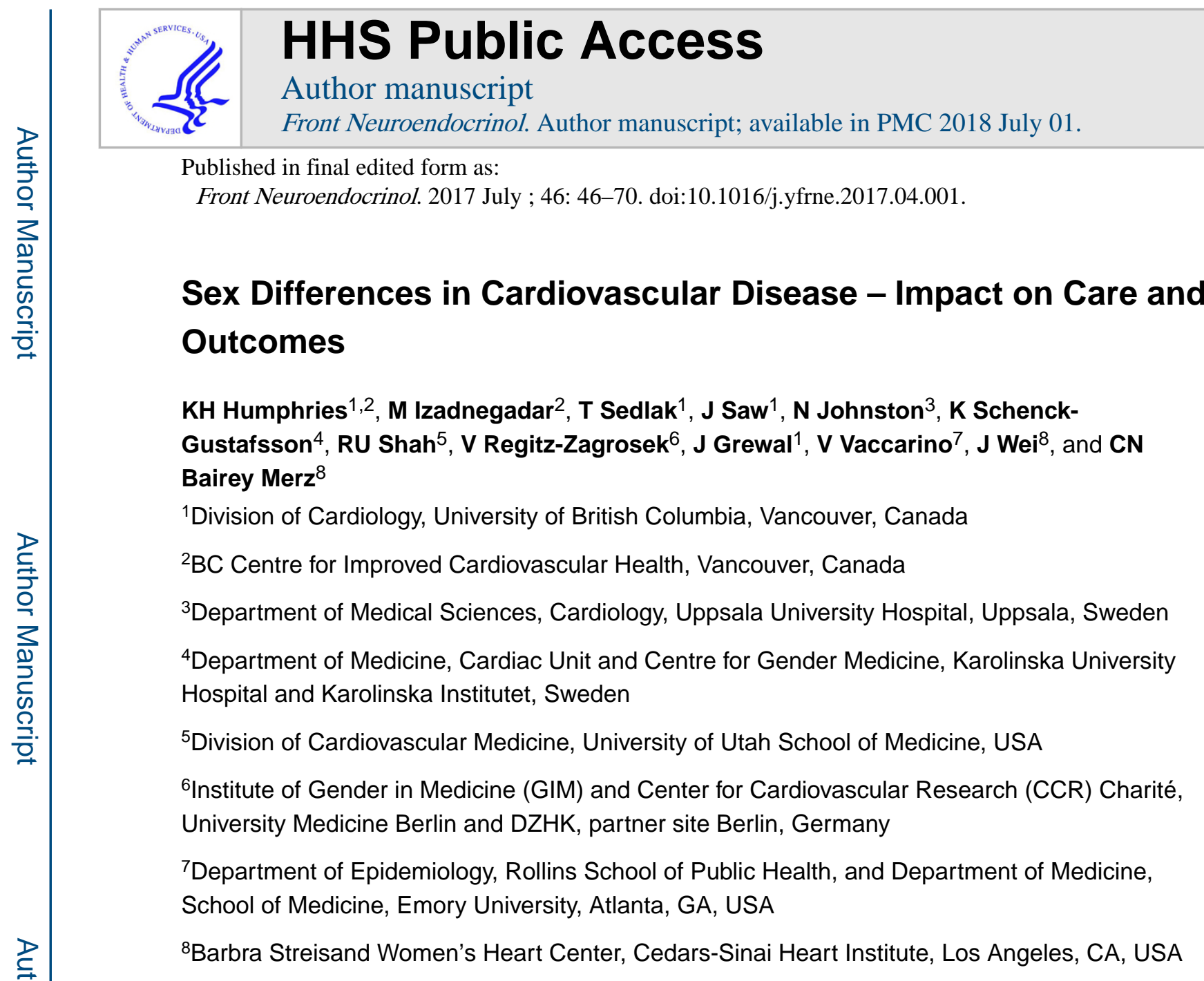

\title{
Keywords
}

Women; Cardiovascular Disease; Sex; Gender

\begin{abstract}
Globally, cardiovascular disease (CVD) is the number one killer of women; one third of female deaths are due to ischemic heart disease and stroke (WHO 2013). Historically considered a 'man's disease', the basic research and clinical trial evidence that underpins our treatment of CVD is largely based on males. The seminal publication from the Institute of Medicine - Exploring the Biological Contributions to Human Health: Does Sex Matter ${ }^{1}{ }_{-}$ laid the foundation for the importance of examining sex and gender in order to better understand human health. Incorporating sex and gender into research leads to better science, and better science has the potential to improve the diagnosis, treatment and outcomes of both women and men. Funding organizations like the National Institutes for Health require the inclusion of women in clinical trials that they fund ${ }^{2}$, when the disease is relevant to
\end{abstract}

\footnotetext{
Address for Correspondence: Karin Humphries, MBA, DSc, Associate Professor, Medicine, UBC-Heart and Stroke Foundation Professor in Women's Cardiovascular Health Providence Health Care Research Institute 1081 Burrard Street, Vancouver, BC V6Z 1Y6, karin.humphries@ubc.ca, Phone: 604-806-8994, Fax: 604-806-9678.

Publisher's Disclaimer: This is a PDF file of an unedited manuscript that has been accepted for publication. As a service to our customers we are providing this early version of the manuscript. The manuscript will undergo copyediting, typesetting, and review of the resulting proof before it is published in its final citable form. Please note that during the production process errors may be discovered which could affect the content, and all legal disclaimers that apply to the journal pertain.
} 
women; the Canadian Institutes for Health (CIHI) asks applicants to indicate how they are taking sex and/or gender into account in the research project ${ }^{3}$. These initiatives have the potential to improve the science that informs care, but more work needs to be done.

In this review, we predominantly focus on an examination of sex differences, which is evolving into a mature science with a body of knowledge that can inform the prevention, diagnosis and treatment of CVD. When available, the impact of gender is also addressed. The definitions of sex and gender, from the CIHI Research, are provided in Figure 1. As research and clinical practice move towards precision medicine, sex and gender differences are a critical component. As an example, sexual dimorphism in drug metabolism impacts both drug effectiveness and adverse drug reactions ${ }^{4,5}$, which directly inform the practice of precision medicine.

\section{Cardiac Risk Factors}

\subsection{Traditional Risk Factors}

In the early 1940's, the seminal, prospective, community-based Framingham Heart Study began following 2,489 men and 2,856 women between the ages of 30 and 74, to examine the epidemiology of CVD and identify patient characteristics that contribute to the development of heart disease. Over the years, the Framingham Heart Study identified age, sex, smoking, high blood pressure, high blood cholesterol, and diabetes as major cardiac risk factors. A more recent global case-control study of risk factors for acute myocardial infarction (AMI) in 52 countries, the INTERHEART study, extended these prior findings. The INTERHEART study identified nine modifiable risk factors, which collectively were shown to explain more than ninety percent of the population-attributable risk (PAR) for AMI in men and women, indicating that the risk of AMI could be reduced by more than ninety percent if all these nine risk factors were eliminated ${ }^{6}$. These modifiable risk factors include: smoking, hypertension, abnormal lipids, diabetes, abdominal obesity, high-risk diet, psychosocial factors, lack of physical activity and absence of alcohol use compared to moderate use ${ }^{7}$.

These established cardiac risk factors play an important role in development and progression of CVD in both men and women. However, there are important sex differences in some of these factors ${ }^{8,9}$. In particular, diabetes and smoking have a stronger association with development of CVD in women than in men, and they are the focus of our review in this section.

1.1.1 Diabetes-The WHO has estimated that the global prevalence of diabetes has increased continuously over three decades, with 422 million adults affected in $2014^{10}$. In many regions, including Canada and the United States, the prevalence of diabetes is higher among men than in women (7.5\% vs. $5.8 \%$ in $\mathrm{Canada}^{11}$ and $13.6 \%$ vs. $11.2 \%$ in the U.S. ${ }^{12}$ ); however, risk of developing CVD is much greater among women with diabetes than men. The Framingham data showed the relative risk of CVD in diabetics as compared to nondiabetics was 1.93 in men and 3.57 in women (Figure 2). This finding of excess risk in women was consistent for risk of heart failure, intermittent claudication as well as overall $\mathrm{CVD}^{13}, 14$. The INTERHEART study also found that diabetes was more strongly associated 
with risk of AMI in women [OR= $4.26(95 \% \mathrm{CI}: 3.68,4.94)]$ than in men $[\mathrm{OR}=2.67(95 \%$ CI: $2.43,2.94)]^{6}$.

In more recent years, several studies have also shown that the impact of diabetes on development of coronary heart disease (CHD) is greater in women than in men. A metaanalysis by Peters et al. which included 858,507 individuals and 28,203 incident CHD events, found that the relative risk (RR) of developing incident CHD, comparing individuals with diabetes to those without diabetes, was $44 \%$ higher in women than in men [ $(\mathrm{RR}=1.44$ (95\% CI: 1.27, 1.63) $]^{15}$. Furthermore, the diabetes-related risk of fatal CHD was higher in women than in men. Huxley et al. also documented a $154 \%$ excess risk of fatal CHD among women with type 1 diabetes than their male counterparts [SMR=2.54 (95\% CI: 1.80, $3.60)]^{16}$.

Our understanding of the mechanism for the observed excess risk of CVD in women with diabetes as compared to men with diabetes is still evolving. A more adverse cardiac risk profile in women with diabetes, as well as greater worsening of cardiac risk status during transition from normoglycemia to diabetes, may play an important role in the excess risk seen in women compared to men ${ }^{17}$. In a meta-analysis comparing diabetics and nondiabetics, the mean differences in systolic blood pressure, total cholesterol, HDL cholesterol, body mass index (BMI) and waist circumference were greater for women than for men ${ }^{18}$. Coupled with this, several studies have highlighted poorer management/treatment of diabetes and its associated risk factors in women as compared to men ${ }^{19}$. A national audit of diabetes care in the UK showed that women with diabetes were $15 \%$ less likely to complete all the recommended care processes, even after taking age, ethnicity, income and BMI into account $^{12}$. Additionally, it has been reported that women with diabetes are less likely to receive lipid-lowering medication ${ }^{19}$, despite evidence that statins reduce adverse vascular events $^{20}$.

Although the observed excess risk of CVD in women with diabetes may be primarily driven by biological factors, gender-related factors also play a role. A Canadian national health survey demonstrated an inverse association between SES and obesity, a major risk factor for diabetes, with a stronger association observed in women than in men ${ }^{21}$. Gendered-based factors such as lower SES, lower levels of physical activity and higher stress levels due to greater family responsibilities are all interrelated and often more prevalent among women than men ${ }^{22-24}$. The combination of these unfavorable factors could also contribute to the excess risk of CVD in women with diabetes.

1.1.2 Smoking-Smoking is a key cardiac risk factor for development of CVD in both women and men. Based on 2014 statistics, the prevalence of smoking is higher in men than in women, both in Canada (21.4\% vs. $14.8 \%$ ) and the U.S. (16.7\% vs. $13.6 \%$ ), with highest rates observed among younger age groups (20-34 years). A recent study, based on four nationwide French registries [including the French Registry of Acute ST-Elevation Myocardial Infarction (STEMI) or non-ST-Elevation Myocardial Infarction (NSTEMI)] indicated that the proportion of young patients ( $<60$ years), particularly women, who present with smoking and/or obesity as their sole risk factors at the time of their hospitalization for STEMI, has continuously increased between the years 1995 to $2010^{25}$. Based on this study, 
approximately $45 \%$ of young French women and $40 \%$ of young men presented with smoking and/or obesity as their only risk factors. The Framingham Heart Study ${ }^{26}$, the INTERHEART Study ${ }^{6}$ and a more recent study by Oliveira et al. ${ }^{27}$ have reported three-fold to eight-fold increased risk of AMI, when comparing ${ }^{27}$ current smokers to never smokers.

Similar to diabetes, the risk of development of CHD due to smoking is greater among women than men. Decades ago, the findings of a large prospective cohort study of 11,472 women and 13,191 men in Copenhagen found that the relative risk of MI was 50\% higher in female smokers than male smokers across all ages, but the largest sex gap was observed among younger adults (Figure 3) ${ }^{28}$. More recently, in a meta-analysis of 17 cohort studies, the relative risk of CHD in smokers compared to non-smokers was $25 \%$ greater in females $\left[\mathrm{RR}=1.25\right.$ (95\% CI: 1.12, 1.39)] compared to males ${ }^{25}$.

The reason for the differential impact of smoking on development of CVD in women versus men is not fully understood. Some have speculated that the use of oral contraceptives may be a contributing factor as it has been shown that the combination of oral contraceptive use and smoking increases CVD risks ${ }^{29,30}$. It has been suggested that the negative impact of smoking on HDL level, may be greater in women than in men and could contribute to the observed excess CVD risk among women ${ }^{31}$. Furthermore, increased levels of hormones including fasting insulin, free testosterone as well as neuroendocrine hormones such as arginine vasopressin AVP have been observed in female smokers, which can potentially lead to higher risk of cardiovascular disease $\mathrm{e}^{32-34}$. These findings are based on small studies and as such our current understanding of the more pronounced negative impact of smoking in females remain largely speculative.

\subsection{Psychosocial Risk Factors}

It has long been observed that acute and chronic emotional stress, and stress-induced physiological perturbations, predict future cardiovascular disease events ${ }^{35,36}$. The large INTERHEART study used an aggregate exposure of psychosocial and mental health factors, including depressive symptoms, perceived home/work stress, low locus of control, and major life events, some of which are driven by both biological (sex-based) as well as socially-constructed (gender-based) factors. The INTERHEART study found that this measure was significantly associated with a 3.5 increased odds of MI in women and 2.6 in men, with a population attributable risk of $40 \%$ in women and $25 \%$ in men ${ }^{37}$. Not all psychosocial risk factors may affect the two sexes equally. Among women, depression, early-life adversities, and posttraumatic stress disorder (PTSD) are especially prevalent and have shown some of the most robust associations with $\mathrm{CVD}^{38}$, 39. Unifying features of these factors include a link with severe stress, chronic dysregulation of neuroendocrine stress systems, and an average onset at young age, possibly resulting in protracted perturbations affecting women many years before CVD becomes manifest ${ }^{40}$. Depression affects approximately $7 \%$ of the population and is about twofold more common in women than in men, with a one-year prevalence of $8 \%$ and $5 \%$, respectly ${ }^{41}$.

Depression in women is also on average more severe than in men and has an earlier age of onset. Among cardiac patients, depression rates are doubled in females compared with males ${ }^{42-44}$. The condition is especially common in young women who have survived an 
$\mathrm{MI}^{42,43}$; about half of women $<55$ years old with a previous MI have a history of major depression ${ }^{43}, 44$.

Depression is a recognized risk factor for incident MI and cardiac death ${ }^{45}, 46$. Among women, depression approximately doubles their cardiovascular risk ${ }^{47,48}$. Two recent followup studies of young adults ( $<40$ years old) found that the impact of depression on CVD risk was higher among women than men ${ }^{49}, 50$. Even among patients referred for coronary angiography depression has been shown to be more predictive of adverse cardiovascular outcomes in young women than in other groups ${ }^{51}$. There are insufficient data on whether these sex-related differences in outcome also apply to patients post-MI. Overall, however, depression seems to affect post-MI prognosis similarly in women and $\operatorname{men}^{52}$.

Severe childhood adversities, such as physical and sexual abuse and child neglect, are unfortunately common in the population, especially among girls, and are emerging risk factors for $\mathrm{CVD}^{53}$, in addition to being frequent precursors of major depression and PTSD. In the Nurses' Health Study II, childhood abuse was associated with approximately a 50\% increased risk of CVD, independent of other risk factors ${ }^{54}$. Early life trauma appears to be a stronger predictor of CVD in younger women than it is in similarly aged men ${ }^{55,56}$. Sexual abuse, in particular, was associated with a fivefold higher rate of self-reported CVD events in the previous 12 months in a national survey of adult women $<55$ years of age ${ }^{57}$, with no association observed among men. In a Finnish community sample of 23,916 individuals < 55 years at baseline, CVD risk among women (but not among men) tracked with the number of childhood adversities ${ }^{56}$; three or more adverse childhood experiences was associated with a threefold increased CVD risk in women, after adjusting for demographic and behavioural factors.

General symptoms of anxiety, measured with a variety of scales, have been associated with incident CVD in a number of studies, although individual study results are heterogeneous and effect sizes in general modest ${ }^{58}$. In contrast, symptoms of PTSD, a condition previously classified among anxiety disorders, have been consistently related to increased risk of CVD $^{59}$. PTSD affects $9.7 \%$ of women (past year prevalence), vs. $3.6 \%$ of men ${ }^{60}$. In a prospective study, women with $\geq 5$ PTSD symptoms had over threefold higher risk of ischemic heart disease compared with those without PTSD symptoms, independent of CVD risk factors and depression ${ }^{61}$. In the Nurses' Health Study II, women who reported $\_4$ PTSD symptoms had a $60 \%$ higher risk of CVD. However, those with a history of trauma but no PTSD symptoms also showed an elevated CVD risk (45\% higher) ${ }^{62}$. Thus, women exposed to psychological trauma may experience an increased risk of CVD even in the absence of PTSD, although the presence of the disorder likely has an additive effect.

There are multiple possible mechanisms linking depression, PTSD, and psychological trauma to CVD. Health behaviors are clearly implicated, such as smoking, poor dietary habits, and physical inactivity. However, lifestyle behaviors do not appear to explain entirely the connection between psychosocial factors and CVD. Alterations in neurobiological stress response pathways, leading to increased inflammation, chronic autonomic dysregulation, endothelial dysfunction and hypercoagulability are all plausible mechanisms that have been demonstrated in human and animal studies ${ }^{40}$.

Front Neuroendocrinol. Author manuscript; available in PMC 2018 July 01. 
In addition to the chronic stressors and mental health disturbances described above, acute stressful events can contribute to CVD morbidity and mortality. Sudden, intense emotions can cause ACS and death in susceptible individuals ${ }^{63-65}$. However, because these events are unpredictable, it is difficult to study them rigorously. In patients with CVD, mental stress can induce transitory coronary perfusion deficits, known as mental stress-induced myocardial ischemia (MSIMI). MSIMI occurs in approximately one third to half of patients with CVD and is associated with approximately a doubling of subsequent CVD events and mortality; similar to ischemia induced by conventional stress testing 66 .

Although studies of MSIMI were performed predominantly in men, emerging data suggest that MSIMI is more common in women than in men. In a study of stable CVD patients, women had a $39 \%$ higher incidence of MSIMI compared with men ${ }^{67}$. Recent studies using myocardial perfusion imaging revealed that young women ( 50 years) with a recent history of MI or stable CAD had 2-3 times the rate of MSIMI compared with men of the same age, while older men and women showed no difference ${ }^{43,68}$. These results were not explained by factors such as severity of disease or traditional CVD risk factors.

Possible mechanisms for the higher rates of MSIMI in women include abnormal coronary vasomotion and peripheral vasoconstriction. MSIMI is at least in part caused by coronary microcirculatory dysfunction, due to a failure of small coronary arteries to dilate during stress $^{69-73}$. As noted in section 4, women have a tendency towards abnormal vasomotion and microvascular dysfunction. Thus, it is possible that women exhibit enhanced microvascular dysregulation with mental stress due to their propensity to vasomotor reactivity ${ }^{74}$. Stress-induced vasoconstriction could be accentuated in young women given their higher baseline levels of inflammation ${ }^{75}$. Overall, these studies have uncovered vulnerability for adverse effects of emotional stress on cardiovascular function in women.

\subsection{Risk Factors Unique to Women}

In addition to the traditional risk factors discussed in section 1.1, a growing number of cardiovascular risk factors unique to women are being identified ${ }^{76}$. In this section we highlight the importance of these risk factors and focus on disorders related to pregnancy and reproduction, specifically hypertensive disorders of pregnancy, gestational diabetes and menarche/menopause. Factors that have been studied, but not yet shown to be strongly associated with an increase in CVD morbidity/mortality include spontaneous preterm delivery, giving birth to a small for gestational age neonate, recurrent miscarriage, polycystic ovarian syndrome and premature ovarian insufficiency ${ }^{77}$. These remain the focus of ongoing study, but will not be reviewed here.

1.3.1 Hypertensive Disorders of Pregnancy (HDP)—HDP can be divided into gestational hypertension and preeclampsia, both of which the American Heart Association considers major risk factors for the development of $\mathrm{CVD}^{76}$. Gestational hypertension is associated with development of hypertension later in life, and possibly associated with development of CVD, hyperlipidemia, chronic kidney disease and diabetes mellitus. A prospective study of over 15,000 women showed that women with gestational hypertension 
in consecutive pregnancies had significantly higher blood pressure later in life than women who remained normotensive ${ }^{78}$.

Women who develop preeclampsia during pregnancy have a twofold or greater risk of developing CVD later in life ${ }^{79-83}$. This increased risk is strongly supported by two systematic reviews that evaluated the risk of late cardiovascular events in women with and without a history of preeclampsia ${ }^{79,84}$. Women with preeclampsia were at increased risk of developing hypertension [RR=3.70 (95\% CI: 2.70-5.05)] at mean follow-up of 14 years), ischemic heart disease [ $\mathrm{RR}=2.16$ (95\% CI: 1.86-2.52)] at mean follow-up of 11.7 years) and stroke $[R R=1.81(95 \%$ CI: $1.45-2.27)]$ at mean follow-up of 10.4 years ${ }^{79}$. Prospective cohort studies have also reported similar findings $85-87$.

It is important to consider whether gestational hypertension and preeclampsia are indeed independent risk factors for CVD or if they act predominantly through traditional risk factors. It is clear that women with HDP are at increased risk of developing hypertension later in life. It may also be that pregnancy unmasks an individual's predisposition to developing hypertension. Some epidemiologic data suggest that the increased risk of late CVD may be attributed to underlying genetic and other cardiac risk factors that are common to both disorders ${ }^{78,88-90}$. It may also be that HDP induces physiologic and metabolic changes that remain after delivery leading to late $\mathrm{CVD}^{91-100}$.

1.3.2 Gestational Diabetes (GDM)-Although most women with GDM are normoglycemic after delivery, they are at high risk for recurrent GDM, pre-diabetes, overt diabetes and/or CVD in the future. In a meta-analysis of 20 cohort studies $(675,455$ women, of whom 10,859 had type 2 diabetes), women with GDM were at significantly higher risk of developing subsequent type 2 diabetes ( $R R=7.43$ (95\% CI: 4.79-11.51) ${ }^{101}$. The relative risk was 4.69 within the first five years after delivery and 9.34 more than five years after delivery. Women with GDM are at greater risk of developing CVD than women with no history of GDM $^{102-105}$. Even mild glucose impairment identifies women at increased risk of future development of $\mathrm{CVD}^{106}$.

1.3.3 Menarche/Menopause-Early menarche appears to be associated with an increased risk of future CVD. A cohort study of 1.2 million women with no known CVD at baseline showed that early menarche (age 10 years or younger) was significantly associated with an increased risk of developing CVD as compared to menarche at age $13^{107}$. Subsequent meta-analysis has shown that every one year increase in age at menarche is associated with a $3 \%$ reduction in CVD related mortality ${ }^{108}$.

In the absence of traditional CVD risk factors, CVD is unusual in premenopausal women. There is a definite shift in the post-menopausal state, which is recognized as a CVD risk factor equivalent to male sex ${ }^{109}$. Early natural menopause ( $\leq 44$ years of age) has been shown to be associated with an increased CVD risk ${ }^{110}$. A recent meta-analysis of 32 studies (310,329 women) showed that early onset menopause before age 45 is associated with a $50 \%$ higher risk of CVD and nearly a 25\% higher risk of CVD death as compared to women in whom menopause occurs later ${ }^{111}$. Among women aged 45 to 49 at the onset of 
menopause as compared to those aged 50 or older there was no increased risk of CVD or death.

Menopause at usual age may not be directly responsible for the increased CVD risk after menopause. Although the CVD incidence rises over time following menopause, there is similarly an increase in risk among men with increasing age ${ }^{112,113}$. An important contributing factor is that postmenopausal women who develop CVD have an increased burden of risk factors compared with those who do not. A large, prospective population based study in Norway (51\% women) showed that the gender gap in risk of MI persists through life but declines with age in part due to levelling off of differences in risk factors between post-menopausal women and middle-aged men with increasing hypertension and dyslipidemia in post-menopausal women ${ }^{114}$. It is unclear whether the increased incident risk of CVD when moving from the pre-menopausal to postmenopausal state, is related to changes in in hormone levels specifically a decline in estrogen levels. There are multiple purported biologic mechanisms for the benefits of estrogen including: 1) decreased LDL and increased HDL cholesterol levels; 2) endothelium dependent vasodilation; 3) enhancing the release or bioavailability of nitric oxide from endothelial cells, resulting in increased vasorelaxation and 4) positive hemostatic effects. Consistent with the notion that menopause may not be directly responsible for the increase in CVD risk after menopause is the lack of benefit from hormone replacement therapy in the Women's Health Initiative primary prevention study and in the HERS trials of secondary prevention ${ }^{115-117}$.

\section{Acute Ischemic Heart Disease}

Ischemic heart disease refers to a spectrum of pathological changes or events that results in myocardial ischemia or actual myocardial injury. The acute presentations of ischemic heart disease include acute coronary syndromes (ACS), myocardial infarction, unstable angina, coronary vasospasm, spontaneous coronary artery dissection, and Takotsubo's Syndrome, as illustrated in Figure 4. Furthermore, evidence supports the role of coronary microvascular dysfunction in ACS due to existing endothelial and non-endothelial dysfunction ${ }^{118}$.

\subsection{Acute Coronary Syndromes (ACS)}

To facilitate immediate treatment, such as reperfusion therapies, it is common to designate ACS based on ischemic symptoms, ECG findings and elevated biomarker values. Patients who develop ST elevation in two contiguous leads are designated as ST elevation MI (STEMI); patient without ST elevation are designated as non-ST elevation MI (NSTEMI); and patients without elevated biomarker values are usually diagnosed as unstable angina (UA). In addition to these categories, MI is also classified into one of 5 types, based on pathological, clinical and prognostic differences. In this section, we will focus on MI type 1, which is related to atherosclerotic plaque rupture, ulceration, fissuring, erosion, or dissection, with resulting intraluminal thrombus in one or more coronary arteries leading to decreased myocardial blood flow or distal emboli with ensuing myocyte necrosis. While patients frequently have severe underlying CAD, 5-20\% may have non-obstructive or no $\mathrm{CAD}$ on angiography. This is particularly true in women ${ }^{119}$. 
2.1.1 Presentation-It is well documented that women are more likely than men to present with NSTEMI ${ }^{120,121}$ and with non-obstructive (i.e. defined as $>50 \%$ disease in any epicardial artery) or normal coronary artery disease (CAD). However, one of the enduring controversies is whether women and men with ACS present with different symptoms. The GRACE registry reported similar proportions of chest pain in men (94\%) and women (92\%), but significantly more atypical symptoms, like jaw pain and nausea in women than men ${ }^{122}$. The GENdEr and Sex determInantS of cardiovascular disease: From bench to beyondPremature Acute Coronary Syndrome (GENESIS-PRAXY) study also reported a high proportion of young adults with ACS reporting chest pain, $86.3 \%$ of men and $81.0 \%$ of women, and again, women reported significantly more non-chest pain symptoms, especially jaw pain, nausea, and back pain. In contrast, patients from the National Registry of Myocardial Infarctions (NRMI), a registry of consecutive AMI patients admitted to 1,658 participating U.S hospitals, reported significantly less chest pain overall, and significantly less in women than men $(58.0 \% \text { vs } 69.3 \%)^{123}$. This study also demonstrated a significant effect of age on the prevalence of chest pain. Among those 45 years of age or less, $85.8 \%$ presented with chest pain; among those 75 years of age or older only $51.3 \%$ presented with chest pain.

The divergent rates of chest pain may, therefore, be due to age difference in these cohorts. The median age in GENESIS-PRAXY was 49 years in both women and men, while in the NRMI cohort $55.1 \%$ of the female subjects were 75 years of age or older, compared to $31.8 \%$ of the males. Given the different findings reported in the literature, definitive conclusions about sex-differences in ACS symptom presentation are lacking, but chest pain is the predominant presentation in both sexes; chest pain presentation declines markedly with age; and there is evidence to suggest women present with more symptoms, generally atypical symptoms, compared to men.

2.1.2 Pathophysiology-Our classic understanding of the pathophysiology of ACS, namely thrombus formation on a ruptured plaque, has evolved over the past two decades ${ }^{124}$. Importantly, this mechanism does not adequately describe the pathophysiology of ACS in women or why women presenting with ACS demonstrate significantly less atherosclerotic burden in the epicardial vessels. In an analysis of data pooled from 11 ACS trials, women were significantly more likely to have non-obstructive CAD disease (15\% vs $8 \%$ ). The more recent Providing Regional Observations to Study Predictors of Events in the Coronary Tree (PROSPECT) study also demonstrated less extensive CAD in women with ACS, both by coronary angiography and intravascular ultrasound.

The PROSPECT study also demonstrated less plaque rupture in women with ACS (6.6\% vs $16.3 \%, \mathrm{p}=0.002)^{125}$. The intravascular ultrasound (IVUS) sub-study of the Relationship Between Intravascular Ultrasound Guidance and Clinical Outcomes After Drug-Eluting Stents (ADAPT-DES) confirmed these findings in their ACS patients by demonstrating both less plaque rupture and lower prevalence of thin cap fibroatheroma (TCFA), in women compared to men. This sex difference was attenuated by age. While overall plaque rupture was less common in women $(23.0 \%$ vs $36.3 \%, \mathrm{p}<0.01)$ a significant sex difference was observed in those $<65$ years of age ( $19.0 \%$ vs $42 \%)$, but not in those $\geq 65$ year of age. 
Similarly, while TCFA was less common in women than men overall, $(44.7 \%$ vs $53.3 \%, \mathrm{p}=$ $0.026)$, the sex difference was again observed in younger adults $(39.2 \%$ vs $53.8 \%, p=0.04)$, but not in those $>65$ years of age ${ }^{126}$. TCFAs are known to be vulnerable to rupture, whereas the thrombi overlying eroded plaques reflect more organization, suggesting longer duration (up to 7 days) prior to presentation with clinical symptoms ${ }^{127}$. Also, the degree of stenosis resulting from plaque erosion is less than from ruptured plaques. The longer thrombus duration seen in plaque erosion also provides greater risks for distal embolization. Microvascular embolization and microvascular occlusion have been shown to cause focal myocardial necrosis ${ }^{128}$.

In a study of atheroma burden and endothelial function in young adults (mean age 49.3 \pm 11.7 years) presenting with early atherosclerosis, a lower burden of atheroma was observed in women compared to men undergoing IVUS of the left main artery (14.1\% vs $23.0 \%, \mathrm{p}=0.002)$ and the left anterior descending artery $(29.3 \%$ vs $40.1 \%, \mathrm{p}=0.001)$. While men had longer segments of endothelial dysfunction (39.2 [0.0 - 71.6] mm vs 11.1 [0.0 - 38.5] mm, $\mathrm{p}=0.002$ ) in women, maximal coronary flow reserve (CFR) was lower in women than men $(2.8$ vs $3.3, \mathrm{p}<0.001)$. The authors concluded that in the setting of early atherosclerosis men had more functional and structural abnormalities in the epicardial vessels, while women had more microvascular dysfunction, independent of endothelial dysfunction in the epicardial vessels ${ }^{129}$.

Coronary vasospasm (CS) can involve the epicardial coronary vessels but it can also occur in microvasculature ${ }^{130}$. It manifests as a sudden, intense vasoconstriction of an artery causing complete or partial vessel occlusion. The pathogenesis of CS is likely multifactorial and appears to vary based on whether it is focal or diffuse in nature. Hyper-reactivity of the coronary vascular smooth muscle has been noted ${ }^{131}$ and is thought to be due to a loss of balance between vascular myosin light chain kinase and phosphatase activity, resulting in a predominance of myosin light chain phosphorylation leading to excessive vascular smooth muscle contraction ${ }^{132}$. Endothelial cell dysfunction also plays an important role as these cells act as paracrine regulators of vascular tone responding to shear stress, myogenic constriction, and bioavailable vasoactive substances ${ }^{133}, 134$.

A key trigger of CS is the autonomic nervous system. Noradrenaline, the neurotransmitter of the efferent sympathetic neurons, triggers vasoconstriction of the vascular smooth muscle cells (VSMC). Clinical studies have demonstrated that CS is induced by catecholamines and by stimuli that increase sympathetic activation, like exercise or stress. Acetylcholine, the neurotransmitter of the parasympathetic neurons, causes vasodilation under physiologic conditions, but can cause vasoconstriction at high doses through the stimulation of the VSMC muscarinic receptors. When the VSMC are hyper-reactive, even low concentrations of acetylcholine may trigger CS. Attacks often occur at night, when vagal tone is higher, supporting the role of parasympathetic activity in vasospasm. However, angina attacks at night occur more frequently during REM sleep, when vagal outflow is reduced ${ }^{134}$. Thus the relationship between sympathovagal balance and coronary vasospasm is complex and not completely understood. There are also environmental factors that contribute to the pathogenesis of this presentation, including smoking, impaired glucose tolerance, and alcohol consumption ${ }^{130}$. 
2.1.3 Diagnosis-Diagnosis of ACS generally includes the elevation of cardiac biomarkers plus evidence of acute myocardial ischemia, including symptoms of ischemia, ischemic ECG changes, or other evidence of myocardial necrosis. The diagnosis of ACS may be missed more frequently in women than men, especially those younger than 60 years ${ }^{135}, 136$. Prior ACS studies have shown that cardiac troponin and CK-MB levels are on average lower in women than in men and that sex-specific cut-off points for high-sensitivity troponin assays may improve the diagnosis of ACS in women ${ }^{137,138}$. When a high sensitivity cardiac troponin I with sex specific diagnostic thresholds (women $16 \mathrm{ng} / \mathrm{L}$ and men $34 \mathrm{ng} / \mathrm{L}$ ) as opposed to a single threshold (50 ng/L) is used, the sex specific threshold doubles the diagnosis of MI in women and identifies those at high risk of recurrent MI and death ${ }^{139}$. Further investigation is needed to determine whether sex specific biomarker thresholds and subsequent reclassification can improve morbidity and mortality in women.

Risk scores for the assessment of ACS clinical severity include Killip class, which classifies patients according to signs of heart failure, as well as the Thrombolysis In Myocardial Infarction (TIMI) risk score and the GRACE score, which predict in-hospital and 6-month mortality risk ${ }^{140}$. There may be sex differences, however, in the interaction of the risk scores on post-ACS prognosis. For example, in a prospective cohort study of 557 patients admitted with ACS, women with low Killip class (Class 1) or normal left ventricular ejection fraction (LVEF) had higher cardiovascular mortality risk than men with the same Killip class or LVEF. Conversely, women with high Killip class (Class3-4) or low LVEF had lower cardiovascular mortality risk than men with the same Killip class or $\mathrm{LVEF}^{141}$. Women with ACS and a high TIMI risk score, which includes clinical, ECG criteria, and biochemical markers, have historically had lower rates of angiography and reperfusion and increased rates of refractory angina and rehospitalization for unstable angina, compared to men ${ }^{142}$. In a more contemporary Belgian cohort of STEMI patients who receive primary PCI, the TIMI risk score was effective in predicting in-hospital mortality for both women and men but performed slightly better in men ${ }^{143}$. Although the GRACE score also does not use sex as a parameter because it was not shown to be a statistically significant predictor of hospital mortality during score development ${ }^{140}$, it may improve risk discrimination in women with the additional parameters of creatinine and cardiac arrest at admission, which may reflect sex differences ${ }^{144}$. Recently the GRACE score was studied in a contemporary Spanish cohort with ACS; the discriminative capacity of the GRACE score was significantly lower in women with STEMI compared to men, but inclusion of female sex did not substantially improve the discriminative ability of GRACE score for STEMI patients ${ }^{145}$. The development of new sex specific scores may be considered for adequate risk prediction in women with STEMI.

Since sex differences exist in the risk assessment and diagnosis of ACS, these may contribute to the sex disparity in reperfusion delays, decreased guidelines-based therapy and increased ACS mortality for young women ${ }^{146,147}$. The Variation in Recovery: Role of Gender on Outcomes of Young AMI Patients (VIRGO) study, a prospective cohort study of women and men younger than 55 years hospitalized for acute MI, sought to characterize phenotypes of acute MI beyond the taxonomy outlined by 2012 Third Universal Definition of MI. The 2012 Third Universal Definition of MI does not provide categories for 1 in 8 
women with acute MI but no obstructive CAD who do not have identifiable mechanisms for myocardial oxygen demand and supply imbalance ${ }^{148,} 149$. The VIRGO taxonomy was developed to provide clinicians with a better tool to describe the diverse acute MI phenotypes that occur in young women, such as coronary microvascular dysfunction, vasospasm, spontaneous coronary artery dissection, and embolism ${ }^{149}$. The VIRGO investigators found that young women with acute MI present with more cardiovascular risk factors, comorbidities, and higher clinical risk scores on average then men, but men present with higher levels of cardiac biomarkers and more classic ECG findings of ischemia ${ }^{150}$. These results are consistent with other studies of women with ACS and highlight the importance of understanding sex differences in the risk assessment and diagnosis of ACS.

2.1.4 Treatment-Overall, the evidence demonstrates less use of evidence-based medications and less invasive interventions in women compared to men. Guidelines for the management of ACS in women are largely based on evidence from randomized clinical trials, but those trials often failed to include sufficient women and/or failed to conduct subgroup analyses to identify potential sex differences in efficacy. While there have been marginal improvements in the proportion of women in clinical trials, rising from $20 \%$ in studies from 1966-2000 to $25 \%$ in studies from 1991-2000, this still falls far short of the proportion of women in the US population (43\%) presenting with $\mathrm{ACS}^{151}$.

2.1.4.1 Delay in Seeking Treatment: Women continue to delay seeking treatment for ACS, despite the favourable impact of early treatment on both survival and clinical outcomes ${ }^{152}$. This delay, defined as the time from symptom onset to presentation for treatment of those symptoms, is often attributed to the differences in women's symptoms of ACS or women's interpretation of those symptoms ${ }^{153}$. While significant reductions in delays within the healthcare system have been noted, delays in accessing the healthcare system remain, especially for women ${ }^{154}$. This delay in treatment-seeking by women appears to cross cultures, and has been observed in Saudi Arabia, China, Brazil, and Norway, and across racial groups, including both white and black women in the US ${ }^{154}$.

2.1.4.2 Invasive Treatment: The most recent Scientific Statement from the American Heart Association on AMI in Women ${ }^{155}$ outlines the evidence for the treatment of women presenting with ACS. In STEMI, primary PCI is the preferred revascularization treatment, if readily available, over thrombolysis ${ }^{156}$. Both women and men derive greater benefit from primary PCI over thrombolysis, but given the higher event rate in women the absolute benefit is greater in women than men, with a reduction of 56 deaths per thousand women treated with PCI compared to a reduction of 42 deaths per thousand men ${ }^{157}$.

In NSTEMI, the role of early invasive management is more complex. The guidelines recommend early invasive management of NSTEMI in women with high-risk features, including elevated troponin levels ${ }^{158}$, based on the results from two meta-analyses ${ }^{159,} 160$ and several post-hoc analyses ${ }^{161-163}$. Despite the evidence for the benefit of primary PCI in the setting of STEMI and an early invasive strategy in high-risk women with NSTEMI, these interventions are used less in women than men with $\mathrm{ACS}^{124}$. Contemporary data demonstrates lower rates of reperfusion therapy (primary PCI or thrombolysis) in women than men with STEMI ( $56.3 \%$ vs $73.0 \%, \mathrm{p}<0.001)$ which was not explained by differences 
in baseline characteristics ${ }^{164}$. Timely reperfusion is also less common in women than men with STEMI, irrespective of modality - door to needle time < 30 minutes: $28.3 \%$ vs $35.2 \%$, $\mathrm{p}<0.001$; door to balloon time $<90$ minutes: $39.0 \%$ vs $44.8 \%, \mathrm{p}<0.0001^{164}$. A similar picture emerges in the setting of NSTEMI, where women are less likely to undergo revascularization. In some studies, the lower rates of revascularization were observed irrespective of angiographic findings ${ }^{165}$, while in the Can Rapid risk stratification of Unstable angina patients Suppress ADverse outcomes (CRUSADE) registry there was no difference in the rate of PCI after accounting for the severity of CAD on angiography $\left[(\text { adjusted OR=0.97 (95\% CI:0.91, 1.03) }]^{166}\right.$.

The risk of bleeding is greater in women than men, following PCI ${ }^{167}$. While a radial approach has been shown to reduce the incidence of peri-procedural bleeding ${ }^{168}$, this approach is more challenging in women, given the smaller size of their radial arteries. Despite more failures with a radial approach in women than men, and more bleeding, the longer term clinical outcomes do not appear to differ between women and men undergoing PCI with radial access ${ }^{169}$.

2.1.4.3 Pharmacological Treatment: The core medications for secondary prevention following an ACS event include: anti-platelet agents; beta-blockers (BB); angiotensin converting enzyme inhibitors (ACE-I) or angiotensin receptor blockers (ARB); and statins. The efficacy of these medications for the reduction of morbidity and mortality has been demonstrated in numerous randomized controlled trials, however, evidence of sex differences in efficacy, if any, are limited, especially for the older medications, as few women were enrolled in these trials.

BB therapy post-MI demonstrates reductions in death, re-infarction, and recurrent ischemia. Treatment with BB is associated with a $21 \%$ reduction in death, a $30 \%$ reduction in sudden death, and a $25 \%$ reduction in re-infarction ${ }^{170}$. Meta-analyses show comparable benefits in both sexes ${ }^{171}$.

Numerous randomized clinical trials have demonstrated improved survival and reduced heart failure and MI with ACE-I use ${ }^{172-174}$. ARBs have been shown to be equally effective and are considered an alternative to ACE-I therapy ${ }^{175}$. Women were under-represented in the trials of ACE-I and ARBs, but meta-analyses of ACE-I trials report similar relative reductions in death, $\mathrm{HF}$ or $\mathrm{MI}$ in the range of $21 \%-29 \% 176,177$.

The Scandinavian Simvastatin Survival Study demonstrated a 30\% reduction in CHD mortality, but the study did not enrol enough women to show a significant reduction in women. Subsequent trials, including the Cholesterol and Recurrent Events (CARE) trial and the Long-Term Intervention with Pravastatin in Ischaemic Disease (LIPID), enrolled sufficient women to demonstrate the benefit of lipid-lowering with statin therapy. Metaanalyses have also demonstrated the efficacy of statins, irrespective of sex ${ }^{178,} 179$. A more recent evaluation of six randomized clinical trials looking at the impact of sex on lipidlowering, cardiovascular events, and adverse events, demonstrated similar changes in lipid levels, but higher rates of discontinuation of therapy due to adverse events in women ${ }^{180}$. 
Meta-analyses of aspirin for secondary prevention demonstrate similar reductions in cardiovascular events in both women and men ${ }^{181}{ }^{182}$. In ACS patients undergoing PCI, clopidogrel reduces the risk of adverse events in both women and men ${ }^{183,184}$. In a prespecified subgroup analysis of the Clopidogrel and Aspirin Optimal Dose Usage (CURRENT-OASIS 7) trial, the treatment effects did not vary by sex, $\mathrm{p}$-interaction $=$ $0.59^{183}$. However, women and men respond differently to glycoprotein IIb/IIIa inhibitors, an intravenous antiplatelet therapy. While glycoprotein IIb/IIIa inhibitor treatment reduced the risk of death or MI at 30 days among men with ACS, women actually exhibited worse outcomes ${ }^{185}$. However, similar to what was seen with an early invasive strategy for NSTEMI, once the analysis was limited to those with elevated troponin levels, both women and men benefited from the use of glycoprotein IIb/IIIa inhibitor therapy. The benefit of anti-platelet therapy in ACS must be balanced against the risk of bleeding, which has consistently been shown to be higher in women ${ }^{186,187}$. The more recent ACC/AHA NSTEMI-ACS guidelines advise careful attention to weight and renal function, when dosing anti-platelet agents to reduce the risk of bleeding in women ${ }^{158}$.

Despite compelling evidence of efficacy for anti-platelet agents, BBs, ACE-I/ARBs and statins, women are less likely to receive these evidence-based medications. Among patients hospitalized for ACS and undergoing PCI, fewer women received aspirin [(adjusted $\mathrm{OR}=0.86(95 \% \mathrm{CI}=0.83,0.86)]$ and glycoprotein $\mathrm{IIb} / \mathrm{III}$ inhibitors [(adjusted $\mathrm{OR}=0.90$ (95\% CI: 0.88, 0.92) ${ }^{188}$. Similar disparities have been noted in the use of BB, ACE-I/ARBs, and statins ${ }^{136,166,189}$. The GRACE study determined that even when women presented with obstructive CAD, there was less use of aspirin (95\% vs $96 \%$ ), beta blockers ( $87 \%$ vs $89 \%$ ), and statins ( $75 \%$ vs $77 \%$ ) compared to men ${ }^{122}$. While the absolute differences in treatment are small, the sex difference consistently trends in the same direction, with women receiving less aggressive management than men.

2.1.5 Outcome-While the incidence of ACS has declined markedly over the past few decades, and survival post-MI has improved significantly, sex differences in outcomes post ACS persist, and vary by age ${ }^{190}$. Young women ( $<50$ years of age) were shown to have a two-fold higher risk of death than men in the same age group based on data from the large NRMI database ${ }^{136}$. Similarly, a Canadian study of 70,628 AMI hospitalizations between 2000-2009 found a significantly higher 30-day mortality rate in women compared to men, but only among those 55 years of age and younger, [OR=1.61 (95\% CI: $1.25,2.08)^{191}$. Emerging evidence regarding the impact of gender, suggests that gender may have a more important role with respect to long-term health-related QoL, than sex ${ }^{192}$, and feminine gender was also shown to be independently associated with recurrent ACS over 12 months, in a cohort of young adults ${ }^{193}$.

Short-term mortality post ACS has been shown to be higher in women, especially after STEMI. In a meta-analysis of 11 randomized clinical trials of ACS, which included over 136,000 patients, the 30-day outcomes in women with STEMI were worse than in men [(adjusted OR= $1.15(95 \% \mathrm{CI}: 1.06,1.24)]$, but in women with NSTEMI [(adjusted OR= 0.77 (95\% CI: $0.63,0.95)$ ] or unstable angina [(adjusted OR= 0.55 (95\% CI: 0.43, 0.70)], the outcomes were better in women than men ${ }^{194}$. In another study of 78,254 patients post MI, in-hospital mortality did not differ by sex, after adjustment for baseline differences, 
however, in the STEMI patients mortality in women remained higher $(10.2 \%$ vs $5.5 \%, \mathrm{p}<$ $0.0001)^{120}$.

Among STEMI patients, treatment with fibrinolysis is associated with a significantly higher risk of bleeding in women than men. In the The Global Utilization of Strategies to open Occluded Coronary Arteries-V (GUSTO V) study, moderate to severe bleeding was seen in $25.2 \%$ of women compared to $14.4 \%$ of men, $\mathrm{p}<0.001$. Adjustment for differences in comorbid conditions did not eliminate the higher risk in women, [OR=1.31 (95\% CI: 1.18, 1.46), $\mathrm{p}<0.001]^{195}$. Intra-cranial haemorrhage (ICH) also occurred significantly more in women $(1.2 \%)$ than men $(0.4 \%), \mathrm{p}<0.01$. Even after adjustment for baseline differences the risk of ICH remained significantly higher in women, [OR=1.9, (95\% CI: 1.2, 2.8, p = $0.004]^{195}$. A recent evaluation of six randomized controlled trials of fibrinolysis in the treatment of STEMI, reported similar findings, with a 1.9 fold higher risk of moderate to severe bleeding in women than men, $1.3 \%$ vs $7.1 \%, \mathrm{p}<0.001^{196}$.

After elective PCI contemporary outcomes no longer differ by sex, though the older data demonstrated worse outcomes in women ${ }^{197}$. Both 30-day and longer-term outcomes are similar in women and men post PCI. However, women still appear to have worse outcomes than men, both in the short term and the longer term, following CABG, though the gap appears to have narrowed over time ${ }^{198,199}$. In the setting of NSTEMI, women undergoing CABG tend to have more post- and peri-operative complications, but the long-term risk of death, MI or stroke does not vary by sex ${ }^{155}$. Women have been shown to have poorer healthrelated quality of life and less functional improvement post-CABG than men $200,201$.

\subsection{Spontaneous Coronary Artery Dissection (SCAD)}

SCAD is an important cause of MI particularly in young women. SCAD is defined as a spontaneous separation of the coronary artery wall that is not iatrogenic or due to trauma, and the contemporary usage of the term is reserved for non-atherosclerotic variant of SCAD. SCAD had been under-diagnosed, however, there has been a surge in SCAD diagnosis in recent years due to increased utilization of coronary angiography for patients presenting with ACS, and increased utilization of high-resolution intracoronary imaging (especially optical coherence tomography [OCT]) that improves diagnosis ${ }^{202-204}$. About half of the $\sim 1500$ reported SCAD cases to-date were published in the past five years ${ }^{202,205-214}$. It is estimated that SCAD is the underlying cause for $1.7-4 \%$ of overall ACS presentation based in contemporary series ${ }^{212,215}$, and accounts for $0.5 \%$ of sudden cardiac death ${ }^{216}$. In young women $<60$ years of age, SCAD accounts for $22-35 \%$ of the ACS presentations ${ }^{208,212,214 .}$

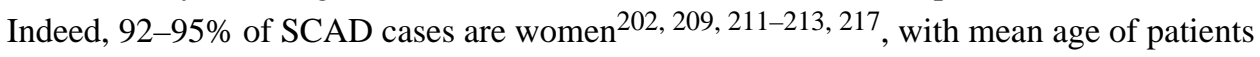
ranging from 44 to 55 years, reflecting a young to middle-aged population $^{202,208,209,211-214}$.

2.2.1 Pathophysiology—SCAD can occur within or between any of the 3 arterial layers (intima, media, or adventitia) of the coronary artery. The two proposed mechanisms for the initiation of the arterial tear were (1) primary intimal dissection of the intimal-luminal interface, and (2) spontaneous haemorrhage into the media such as through rupture of vasa vasorum, both of which results in intramural hematoma within the false lumen of the arterial 
wall $^{218}$. Compression of the true lumen by the intramural hematoma can then result in myocardial ischemia and infarction.

The underlying cause of SCAD appears to be multifactorial. In most cases, there is an underlying predisposing arteriopathy that weakens the arterial wall, increasing the susceptibility for dissection. This arterial fragility may be compounded by a precipitating stressor, either an emotional or physical stressor, which then potentiates the arterial tear. Many predisposing non-atherosclerotic arteriopathies have been associated with SCAD, with the most prevalent being fibromuscular dysplasia, which was reported in 50-80\% of SCAD

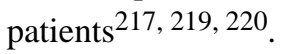

2.2.2 Diagnosis-Early and correct diagnosis of SCAD is paramount since the management is different from atherosclerotic coronary disease. Despite the limitations of coronary angiography, it remains the first-line imaging tool for SCAD given its widespread availability. However, since it does not image the arterial wall, dedicated intracoronary imaging [e.g. OCT and IVUS may be required to confirm the presence of intramural hematoma and/or intimal tear. Contemporary SCAD angiographic classification has been proposed by Saw: type 1 describes the appearance of arterial wall contrast staining with multiple radiolucent lumens; type 2 describes diffuse stenosis of varying severity and length (typically $>20 \mathrm{~mm}$ ); and type 3 describes focal or tubular (typically $<20 \mathrm{~mm}$ ) stenosis mimicking atherosclerosis, thus requiring intracoronary imaging to confirm diagnosis ${ }^{221}$. Utilizing this classification in a series of 203 dissected arteries, type 2 SCAD was observed in $67.5 \%$ of cases, type 1 in $29.1 \%$ of cases, and type 3 in $3.4 \%{ }^{221}$. Several series have reported diffuse smooth stenosis to be the most common angiographic manifestation 207, 212, 214

2.2.3 Treatment-The ideal management of SCAD is yet to be determined since there are no published randomized trials, and current management recommendations are based on expert opinions from observational studies $155,202,208,222$. As shown in Figure 9, conservative approach is preferred based on published data that revascularization is associated with high failure rates, and SCAD arteries tend to heal spontaneously in the vast majority of cases. However, a small proportion of patients may require revascularization, such as those with ongoing or recurrent ischemia, hemodynamic instability, ventricular arrhythmias, or left main dissection. In such cases, coronary stenting is preferred if the anatomy is suitable, otherwise coronary artery bypass surgery should be considered.

Generally, aspirin and beta-blockers are administered acutely and long-term. Beta-blockers may reduce coronary arterial shear stress such as with aortic dissection ${ }^{223}$, furthermore they reduce ventricular arrhythmias and improve long-term survival in post-MI patients ${ }^{126,158}$. Some authors advocate a short duration of clopidogrel in addition to aspirin, to counteract the prothrombotic milieu of intimal disruption, and to reduce false lumen thrombus ${ }^{224}$. However, heparin and thrombolytic therapies are generally avoided, because of the risk of extension of dissection ${ }^{225,226}$. Angiotensin converting enzyme inhibitor or angiotensin receptor blocker may be administered for those with significant left ventricular dysfunction ${ }^{227}$. Statins may be used in patients with underlying dyslipidemia and calcium channel blocker and nitrate therapies may be administered in patients with recurrent chest 
pain post-SCAD who are unresponsive to $\mathrm{BB}$. Cardiac rehabilitation has been demonstrated to be safe and effective post-SCAD event, and is highly recommended to improve the psychosocial and physical wellbeing of survivors 228 .

2.2.4 Outcome-In contemporary series, the acute outcomes with SCAD are relatively good with in-hospital mortality $<5 \%$, and recurrent MI or need for urgent revascularization in 5-10\% $206,208,210$. Subacute MACE within 2 year follow-up were reported in 10-20\% of patients, with recurrent SCAD event-rate $\sim 15 \% 217,224$. Although long-term survival is $>95 \%$ in SCAD patients, long-term MACE rates were reported to be high at $15-37 \%$ at $5-7$ years, and estimated at $\sim 50 \%$ at 10 years $^{206,210,214,221,229}$. Recurrent SCAD rates at 4-5 years may be as high as $27 \%^{209,214}$. Such high follow-up event-rates emphasize the importance of cardiovascular follow-up of SCAD survivors.

\subsection{Takotsubo's Syndrome (TTS)}

TTS is an acute and typically reversible HF syndrome that is increasingly recognised since the first published case in 1990. The name "Takotsubo" was derived from the left ventricle at end-systole having the appearance of the octopus pots of Japanese fisherman in the Hiroshima fish markets. Many alternatives names have been used, such as stress-induced cardiomyopathy, apical ballooning syndrome, and "broken heart syndrome". Since the diagnosis is based on several clinical observations, there is consensus that the description as a "clinical syndrome" is more appropriate than "cardiomyopathy"230. TTS is distinct from ACS, although the presenting features are very similar to MI presentations with chest pain and ischemic ECG changes. However, it probably represents a form of acute catecholaminergic myocardial stunning. It is estimated that 50,000 - 100,000 cases occur annually in the US, accounting for $1-2 \%$ of patients with suspected $\mathrm{ACS}^{231}$. It is often triggered by emotional or physical stress, and occurs predominantly in post-menopausal women in $\sim 90 \%$ of cases ${ }^{231}$.Several diagnostic criteria have been proposed in the past decade, including those from the Mayo Clinic, the Japanese Takotsubo Cardiomyopathy Group, the Gothenburg Group, and the Takotsubo Italian Network. The Heart Failure Association of the European Society reviewed and adapted these criteria, which was published in the position statement in $2016^{230}$. The key diagnostic features for TTS are: (1) transient regional wall motion abnormalities of the left or right ventricle often preceded, but not always, by a stressful trigger; (2) regional wall motion abnormalities usually extend beyond a single epicardial artery distribution; (3) absence of culprit atherosclerotic/nonatherosclerotic $\mathrm{CAD}$ or other pathological conditions to explain the ventricular dysfunctional pattern (e.g. myocarditis, cardiomyopathy); (4) new and reversible ECG abnormalities during the acute phase (3 months); (5) significant elevation of serum natriuretic peptide during the acute phase; (6) relatively small elevation in cardiac troponin level in disparity to the amount of dysfunctional myocardium present; (7) recovery of ventricular systolic function on cardiac imaging at 3-6 months follow-up.

Patients typically present with acute chest pain, breathlessness, and palpitations. And in more severe cases, they may present with pre-syncope or syncope from ventricular arrhythmias, severe left ventricular outflow tract obstruction, or cardiogenic shock ${ }^{80}$. The typical apical ballooning appearance is observed in $75-80 \%$ of cases, and the remaining 
atypical variants include mid-ventricular, basal, and focal akinesis variants ${ }^{230}$. Although this is typically a reversible disorder, it is associated with major complications in $\sim 50 \%$ of cases. These include acute HF, left ventricular outflow tract obstruction, mitral regurgitation, cardiogenic shock, atrial and ventricular arrhythmias, apical thrombus formation, pericardial tamponade, and ventricular rupture ${ }^{230}$. Treatment consists predominantly of supportive HF therapy, and repeat imaging should be performed to assess for recovery of ventricular function in 3-6 months ${ }^{230}$. The reported in-hospital mortality ranges 1-5\%, with subsequent recurrence rate of 5-22\%, 30-day MACE of 7\%, and 5-year mortality of 3-17\% $80,230$.

\section{Stable Ischemic Heart Disease (SIHD)}

The conventional paradigm that flow-limiting atherosclerosis of one or more epicardial vessels underlies stable ischemic heart disease, fails to recognize many other mechanisms that may alter determinants of myocardial oxygen supply-demand and result in ischemia. In this section we review both obstructive and non-obstructive etiologies of SIHD and we examine both the coronary microvasculature and epicardial vessels.

\subsection{Stable Angina}

Stable angina pectoris is more common in women than $\operatorname{men}^{232,233}$. Normal or nonobstructive CAD is observed more frequently in women with angina than in men ${ }^{234}$. Women have more diverse symptoms than men. Cardiovascular risk evaluation and diagnosis of ischemic heart disease is thus more difficult in women. Angina pectoris is more debilitating in women than men 235 .

3.1.1 Prevalence of stable angina-From population studies, it is apparent that unlike the male excess of MI, women have a similar or slightly higher prevalence of stable angina compared to men. In a systemic review and meta-analysis of prevalence of angina using the Rose Questionnaire in 31 countries, the pooled estimates for women were $6.7 \%$ compared to $5.6 \%$ in men ${ }^{232}$. This finding was consistent across countries and cultures (Figure 5). The Rose questionnaire, although a standardized instrument for diagnosing angina, was developed and validated in men and based on the assessment of typical chest pain associated with obstructive CAD. Studies using this questionnaire may therefore in fact underestimate the prevalence of angina in women who suffer from symptoms other than those described as typical.

In a prospective ambulatory cohort study from Finland, the age-standardized annual incidence of angina was similar in both sexes ${ }^{236}$. Angina in this study was defined as "nitrate prescription angina," (i.e. physician diagnosed angina and prescribed nitrate drugs) or "test-positive angina" (i.e. physician diagnosed angina based on an abnormal noninvasive test indicative of myocardial ischemia). These inclusion criteria may also underestimate the prevalence of angina in women, as women in general are less likely to undergo non-invasive and invasive testing and be treated according to guidelines.

In the National Heart and Lung and Blood Institute survey, the prevalence of angina in women $<65$ years was 5-7\% and in men 4-7\%, and in the age group 65-84 years, 10-12\% in women and $12-14 \%$ in men $^{233}$. The higher prevalence of angina in younger and middle- 
aged women compared to men may reflect the higher rate of microvascular angina. In the Swedish Coronary Angiography and Angioplasty Register (SCAAR) study in 12,200 patients undergoing diagnostic coronary angiography for stable angina, almost $80 \%$ of women $<65$ years with stable angina had either no CAD or non-obstructive CAD (Figure $6)^{237}$. In older age groups, obstructive CAD is more common in both men and women.

A higher prevalence of angina in women is also reported for different ethnic groups. In the United States the estimated age-adjusted prevalence of angina in women age $\geq 20$ years is $4.1 \%$ for non-Hispanic white women, $4.5 \%$ for Mexican-American women, and $6.7 \%$ for non-Hispanic black women ${ }^{233}$. Rates for men in these three groups were $4.1 \%, 3.5 \%$, and $4.4 \%$, respectively. The higher rates of angina in the non-Hispanic black female population may in part be explained by the high prevalence of cardiovascular risk factors ${ }^{238}$.

3.1.2 Pathophysiology-Angina pectoris is the medical term for chest pain due to ischemic heart disease. It occurs when the supply of oxygen to the myocardium is less than the demand. The most common cause of angina is narrowed or blocked coronary arteries. In women, angina with normal or non-obstructive CAD occurs more often than in men as reported in several studies in patients undergoing diagnostic coronary angiography for stable angina. In the Coronary Artery Surgery Study (CASS) registry, in approximately 25,000 patients, $39 \%$ of women compared with $11 \%$ of men had normal coronary arteries ${ }^{239}$. Data from 375,886 patients in the American College of Cardiology-National Cardiovascular Data Registry (NCDR) showed that no obstructive CAD was significantly higher in women than in men $(51 \% \text { vs. } 32 \%)^{240}$. In the Swedish SCAAR report non-obstructive CAD was more common among women than men in all age groups (Figure 6) ${ }^{237}$. This high prevalence in women has also been confirmed by the WISE study, in which $62 \%$ of women referred for coronary angiography had no obstructive $\mathrm{CAD}^{241}$.

The underlying mechanism of angina pectoris, in the absence of significant CAD, remains unclear $^{242}$. Studies using IVUS or optical coherence tomography provide evidence that cholesterol deposition may be found in seemingly "normal" coronary arteries. T he epicardial coronary arteries are smaller in women, and smaller coronary arteries may be associated with ischemia at a lower plaque burden. Other causes include coronary microvascular dysfunction and coronary artery spasm as discussed in further detail elsewhere in this review.

3.1.3 Diagnosis-Current guidelines recommend a stepwise approach for decision making in patients with suspected stable angina ${ }^{243}$. The first step is to assess the patient's pre-test probability (PTP) of CAD. The major determinants of PTP include sex, age and symptom description as typical, atypical or non-anginal. Typical chest pain is defined as substernal chest pain provoked by exertion or emotional stress and relieved by rest and/or nitrates. The second step is non invasive or invasive testing to establish the diagnosis of CAD after which treatment is initiated.

The use of PTP has its limitations, particularly in women. PTP is based on studies performed several decades ago and it assesses the likelihood of obstructive CAD based on typical symptoms ${ }^{244}$. Women more often than men have symptoms described as atypical and 
normal or non-obstructive CAD, on angiography. Hence categorical use of PTP in women may lead to an under-diagnosis and subsequent under-treatment of ischemic heart disease in women not caused by obstructive CAD. These limitations are important to acknowledge and PTP, especially in women, should be used in the context of other clinical information (i.e. cardiovascular risk).

There are many different CVD risk assessment tools available to physicians ${ }^{245}$. They are often easy to use and establish a common ground for lifestyle and medical intervention.

However, these scores focus on the10-year risk for coronary heart disease rather than longterm risk for CVD. A woman's risk for stroke and HF through middle and older age typically exceed their risk for coronary heart disease, which contrasts with the pattern observed in men.

These scores are also limited to the major traditional risk factors and may not fully quantify risk in women, especially in younger women and those with non-obstructive CAD. The Reynolds risk score is an example of a novel attempt to more accurately classify risk in women by adding biomarkers reflective of the complex biological process underlying ischemic heart disease $\mathrm{e}^{246}$. However, this score is not endorsed as there are no data to support the association between a reduction in hsCRP and improved clinical outcomes.

As outlined in the 2011 CVD prevention guidelines for women, history of pregnancy complications (e.g. gestational diabetes mellitus, preeclampsia, preterm birth, or birth of an infant small for gestational) should be routinely included ${ }^{76}$. These guidelines also recommended heightened awareness of conditions more common in women such as depression and autoimmune diseases. Further studies are needed on how inclusion of female-specific factors may improve women's risk classification.

3.1.3.1 Diagnostic Modalities: Symptomatic women with suspected SIHD should undergo initial non-invasive diagnostic testing for myocardial ischemia and prognosis depending on their risk. The 2014 AHA consensus statement for the role of noninvasive testing in the clinical evaluation of women with suspected SIHD outlines an algorithm for diagnostic testing (Figure 7$)^{247}$. Low-risk women generally should not undergo any diagnostic testing, but low-intermediate risk or intermediate-risk women should be considered for exercise ECG if she has a normal or interpretable ECG and able to exercise. Intermediate-risk women with resting ST-segment abnormalities or high-risk women should be considered for stress imaging (myocardial perfusion imaging [MPI], stress echocardiography, or stress cardiac magnetic resonance [CMR] imaging) or coronary computed tomography angiography (CCTA). Exposure to ionizing radiation should be discussed with the patient, including the test's effective radiation dose and estimation of cancer risk, and the lowest dose should be used for all patients.

If an intermediate-risk woman has a normal baseline ECG and can exercise, exercise ECG is the recommended initial non-invasive test of choice given its high negative predictive value, ability to assess functional capacity, and evidence from the WOMEN trial of similar 2-year clinical outcomes for women randomized to exercise ECG compared with exercise MPI while providing significant cost savings ${ }^{248}$. Calculation of the Duke Treadmill Score has 
diagnostic and prognostic value in women and can help predict the risk of significant coronary stenosis 249,250 .

More recently for the assessment of low to intermediate -risk patients, the PROMISE trial showed that CCTA and functional testing had similar 2-year clinical outcomes when used as an initial diagnostic strategy ${ }^{251}$. Post-hoc analysis of the PROMISE study, however, identified sex-differences in risk assessment, noninvasive test outcomes and noninvasive test prognostic value, highlighting the importance of sex-specific approaches for the evaluation of $\mathrm{CAD}^{124,252}$. For example, not only were women more likely to be characterized as lower risk by providers and by risk scores despite having a greater number of cardiac risk factors, women were also less likely to have a positive test ${ }^{252}$. The Diamond and Forrester risk score, which classifies chest pain as typical, atypical, and nonanginal, was predictive of a positive test in men but not in women. Finally, the PROMISE study concluded that women tend to derive more prognostic value from a CCTA than from traditional functional testing, whereas men tend to derive similar prognostic value from both functional testing and $\mathrm{CCTA}^{124}$, which likely reflects the lower rates of obstructive CAD in women with SIHD and suggests that the detection of nonobstructive atherosclerosis is clinically important in women with SIHD 253 .

3.1.4 Treatment-The aims of the management of stable angina are to reduce symptoms and to prevent future cardiovascular events. As with ACS patients, management includes lifestyle modifications, control of cardiovascular risk factors, pharmacological therapy and invasive therapy (PCI or CABG) when significant obstructive CAD is present ${ }^{243}$. These recommendations are similar for men and women. Medical therapy may include a combination of anti-hypertensive medications (BBs, calcium channel blockers, ACEinhibitors, RAAS-inhibitors), lipid-lowering drugs, and nitrates (long and/or short-acting). Low-dose aspirin is recommended in the presence of obstructive CAD. Dual-antiplatelet therapy is prescribed for a restricted period of time after PCI and stent implantation. Although there are sex differences in the reported side effects of a number of cardiovascular drugs (e.g. calcium channel blockers) there are at present, no separate dosage recommendations for men and women.

3.1.5 Outcome-The prognosis of stable angina in women is difficult to assess. The difficulties lie in how angina is defined and confirmed in the different study populations, as well as which endpoints are evaluated. Much of the prognostic data available is on patients with ACS and hard endpoints such as MI and death. The pathophysiology of stable angina however differs from acute CAD. In patients with non-obstructive CAD functional testing for microvascular disease for example is not routinely carried out. Patients with microvascular disease have worse prognosis with an increased risk for cardiovascular events including death ${ }^{254}$. Inclusion of patients suffering from non-cardiac chest pain may dilute results and contributes to the misconception of a benign prognosis in women with stable angina.

An additional problem in interpreting studies of stable angina in women is that for every step in the referral cascade the proportion of women to men decreases. The worse prognosis observed for women compared to men in the Euro Heart Survey of Stable Angina may, as 
the authors suggest, be a consequence of the selected nature of the population (Figure 8 ) $^{255}$. In this survey women compared to men were less likely to undergo coronary angiography ( $31 \%$ vs $49 \%$ ) despite a higher angina class. A worse prognosis for women compared to men who underwent PCI for stable angina or ACS was also observed in a Swedish-British registry study in 458,261 patients, in which women experienced higher all-cause mortality at 30-days and 1 year $^{256}$. The excess mortality could partly be explained by higher rates of procedural complications (e.g. vascular complication and bleeding).

Another factor which may impact and contribute to a worse prognosis in women is less optimal medical treatment ${ }^{255}$. Under-treatment of angina is especially a problem in women with angina and normal coronary arteries who are often assured of the benign nature of their condition. Lack of appropriate medical treatment may contribute to the persistent chest pain, which is common in women with angina, both with or without obstructive CAD. Women with angina more often repeatedly seek healthcare contact, are hospitalized and undergo repeat coronary angiography, which impacts negatively on quality-of-life ${ }^{235}$.

\subsection{Coronary Microvascular Dysfunction (CMD)}

Up to $30 \%$ of women and 5-10\% of men with signs and symptoms of ischemia will have no obstructive CAD on invasive coronary angiography $234,257,258$. Further, among women presenting for evaluation of suspected ischemic symptoms, a diagnosis of normal coronary arteries is five times more common, as compared to men ${ }^{259}$. The WISE study suggests that more than half of these patients have CMD indicated by abnormal coronary blood flow $(\mathrm{CBF})$ on invasive coronary reactivity testing (ICRT ${ }^{260}$. Further up to $70 \%$ will have a pathological response to acetylcholine testing indicating abnormal coronary vasomotion ${ }^{261}$.

3.2.1 Pathophysiology-A subset of these patients have microvascular angina due to $\mathrm{CMD}^{262}$. CMD refers to abnormalities in the vasomotor or metabolic regulators of the smaller resistance coronary arterioles ( $<500 \mathrm{um})$, although structural abnormalities of the microcirculation (for example smooth muscle cell hypertrophy) have been described by some studies ${ }^{263}$. Suggested mechanisms of CMD include altered regulation of coronary microcirculation through autonomic dysregulatory and endothelial mechanisms, generalized vascular disorder and abnormal subendocardial perfusion ${ }^{264}$. Other suggested contributing factors include inflammation, hyperinsulinemia, enhanced sodium-hydrogen exchange, hormonal deficiency, abnormal pain perception and inherent pathogenetic pathways. Endothelial dysfunction in particular is supported by various studies of the pathophysiology of the condition. In CMD, endothelium-dependent, but not endothelium-independent, vasodilatation is thought to be impaired. Elevated endothelin activity ${ }^{265}$ blunted nitric oxide (NO) and endothelin responsiveness to intravenously infused insulin ${ }^{266}$ in patients with angina and normal coronary arteriograms provides a pathophysiological basis for the demonstration of endothelial dysfunction in such patients. Interestingly, an NO-dependent vasodilatation mechanism appears to be suboptimal and defective in patients with $\mathrm{CMD}^{267}$.

\subsubsection{Diagnosis}

3.2.2.1 Non-invasive Testing: Non-invasive testing such as exercise treadmill testing, nuclear myocardial perfusion imaging, and stress echocardiography for CMD remain 
insensitive 268,269 although positron emission tomography (PET) is a gold standard ${ }^{270}$, and newer imaging modalities such as adenosine cardiac magnetic resonance imaging (CMRI) hold promise. CMRI allows evaluation of subendocardial perfusion, fibrosis and microinfarction, assessment of left ventricular function and mass and measurement of myocardial flow reserve using a myocardial perfusion reserve index (MPRI). In a recent study from the WISE of 128 women with signs and symptoms of ischemia but no obstructive CAD, $11 \%$ of women had myocardial scar by late gadolinium enhancement (LGE) and $69 \%$ had an abnormal MPRI on CMRI $(\leq 1.8)^{155}$. Future research is needed to determine sensitivity and specificity of CMRI in the clinical setting as MPRI is not routinely measured outside the research field.

3.2.2.2 Invasive Testing: CRT is an alternate gold standard technique for evaluation of CMD. Intra-coronary infusion of adenosine, acetylcholine and nitroglycerin allows assessment of microvascular and macrovascular endothelial and nonendothelial pathways. The normal response to intra-coronary infusion of adenosine is a $\geq 2.5$ increase in CFR. Therefore, a CFR of $<2.5$ defines CMD and examines the non-endothelial dependent microvasculature 271 . Acetylcholine uniformly dilates both the microvasculature and macrovasculature in an endothelial-dependent fashion. The normal response to acetylcholine is an increase in CBF of $>50 \%$ above baseline and endothelial dysfunction may be manifest by a significant attenuation, no change or even a decrease in $\mathrm{CBF}^{272}$. Finally, nitroglycerin tests the non-endothelial macrovascular pathway and lack of a response to nitroglycerin may indicate smooth muscle dysfunction.

3.2.3 Treatment-Usual care for patients with angina and non-obstructive CAD is not well defined and rates of prescription use are low $237,257,259,273$. An analysis of medication use for all patients $\geq 20$ years with stable angina who underwent index coronary angiography in British Columbia, Canada, from 2008-2010 revealed that only 14\% and 26\% of patients with no CAD and non-obstructive CAD respectively were prescribed an ACE-I, a statin and an anti-anginal such as a BB within 90 days of angiography (manuscript in press).

Regarding non-pharmacologic techniques, exercise, cognitive behavioral therapy, spinal cord stimulation and enhanced external counterpulsation have been shown to increase coronary blood flow, reduce duration and frequency of anginal attacks and reverse ST segment depression during stress testing compared to controls ${ }^{274}$.

Regarding pharmacologic management, prior studies have demonstrated improvements in chest pain with angi-anginals such as beta-blockers, nitrates and calcium channel blockers ${ }^{275}$. Further, studies have shown improvements in both angina scores and ICRT with statins ${ }^{276,277}$ and $\mathrm{ACEI}^{260,278}$. Several recent studies have evaluated the effect of ranolazine in patients with $\mathrm{CMD}$, with conflicting results. In a double-blind, placebo-controlled, crossover design trial, Mehta et al randomized 20 women with ischemia but no obstructive coronary lesions to ranolazine 500 to $1000 \mathrm{mg}$ BID versus placebo ${ }^{196}$. There was a significant improvement in the Seattle Angina Questionnaire (SAQ) in patients on ranolazine for 4 weeks. Villano et al. investigated the effects of 375mg BID of ranolazine for 4 weeks in CMD and demonstrated significant improvements in SAQ and quality of life (QoL) scores in the ranolazine $\operatorname{arm}^{279}$. More recently, however, Bairey Merz et al published the WISE 
trial, which randomized 128 patients with $\mathrm{CMD}^{155}$. After a 2-week course of ranolazine, patients were evaluated with regards to SAQ, QoL and CMRI and there was no improvement in SAQ scores after this short time period.

Other possible therapeutic targets in CMD involve phosphodiesterase-5 inhibition with Sildenafil, a phosphodiesterase inhibitor that may target the nitro oxide pathways in $\mathrm{CMD}^{280}$; low dose tricyclic anti-depressants (TCAs) such as imipramine and amitriptyline which may be useful in patients with cardiac nociceptive abnormality and uncontrolled chest pain despite traditional use of anti-anginals ${ }^{281}$; and $\mathrm{L}$-arginine which is a precursor of nitric oxide and mediates vascular smooth muscle cell relaxation and inhibits platelet aggregation ${ }^{282}$. Finally, Nicorandil and Ivabradine, two drugs only available in Europe, improved angina, but these were small studies 283,284 .

3.2.4 Outcome-Early studies reported angina with non-obstructive CAD as a benign condition 285,286 . However, more recent and larger studies have shown an adverse prognosis with a $2.5 \%$ per year major adverse cardiovascular event rate including hospitalization for MI, HF, stroke, or cardiovascular death ${ }^{234,254,257,259}$. In addition, these patients have high rates of recurrent chest pain, poor QoL and higher rates of functional disability, angina hospitalizations and repeat angiography than patients with 1-vessel obstructive $\mathrm{CAD}^{287}$. In the absence of effective treatment, patients with angina and non-obstructive CAD continue to seek help in the emergency services and pose a substantial health care burden. For women with signs and symptoms of ischemia but non-obstructive CAD the average lifetime cost for ischemic heart disease is $\$ 767,288$, comparable in magnitude to the more than $\$ 1$ million dollars for obstructive $\mathrm{CAD}^{287}$.

3.2.4.1 Sex Differences in Adverse Outcomes: Women with no obstructive CAD tend to have an adverse prognosis compared to men. A study by Humphries et al., in a large population-based setting, assessed the outcomes (re-hospitalization for ACS or chest pain) of 3,647 patients undergoing coronary angiography for stable angina or ACS, but had angiographically normal coronaries and found that women were 4 times more likely to be rehospitalized with a diagnosis of ACS or chest pain requiring angiography within the first 6 months ${ }^{235}$. Further, Sedlak et al. evaluated the outcomes of 4,184 women and 9,511 men with chest pain and normal or non-obstructive $\mathrm{CAD}$ and reported that as compared to patients with no $\mathrm{CAD}$, women with non-obstructive $\mathrm{CAD}$ had a 3.5 times greater hazard of MACE (i.e. hospitalization for MI, HF, stroke, or all-cause mortality) within the first year post angiography $[\mathrm{HR}=3.58(95 \% \mathrm{CI}: 1.87,6.86)]^{234}$. In contrast, the hazard of MACE in men with non-obstructive CAD was similar to men with no CAD [( $\mathrm{HR}=0.82$ (95\% CI: 0.35, 1.93)].

\section{Heart Failure (HF)}

$\mathrm{HF}$ is a clinical syndrome that can result from many different processes. The European Society of Cardiology (ESC) defines HF as "a clinical syndrome characterized by typical symptoms that may be accompanied by signs caused by a structural and/or functional cardiac abnormality, resulting in a reduced cardiac output and/or elevated intracardiac pressures at rest or during stress"288. Etiologies, or the structural and/or functional cardiac

Front Neuroendocrinol. Author manuscript; available in PMC 2018 July 01. 
abnormalities, vary widely and include hypertension, $\mathrm{CAD}$, and valvular disease, among others.

$\mathrm{HF}$ is a worldwide epidemic, affecting almost six million adults in the United States and over 20 million adults worldwide ${ }^{289,290}$. Some data suggest that the incidence is increasing 291,292 , while other suggests decreasing incidence 293,294 . While definitions vary between studies, HF is consistently associated with older age. The Rotterdam Study, which used physician review to define HF, showed that prevalence increased from $0.9 \%$ among 55 to 64 year olds, to $17.4 \%$ among those aged 85 years and older ${ }^{295}$; other observational studies echo this finding ${ }^{291}$. Given the longer life expectancy of women, we can expect continued population growth of older women with HF.

\subsubsection{Pathophysiology}

Left-sided HF can broadly be classified as HF with preserved ejection fraction (HFpEF) or HF with reduced ejection fraction (HFrEF), with EF of $\$ 40 \%$ to $\mathbf{5 0 \%}$ typically used as the cut point for HFrEF. Compared to patients with HFrEF, patients with HFpEF are more likely to be women, representing almost two-thirds of the HFpEF population ${ }^{294}$. In reality, HFpEF is distinctly different from HFrEF, with a different set of risk factors. Hypertension, diabetes, and obesity have all been associated with $\mathrm{HFpEF}^{296}$. In fact, while the association between hypertension and HF is weak compared to other risk factors, hypertension is highly prevalent and accounts for over a fourth of HF cases among women. In other words, hypertension has the highest population attributable risk for HF among women. Conversely, the association between diabetes and HF is stronger, yet diabetes accounts for $10 \%$ of $\mathrm{HF}$ among women ${ }^{296,297}$. In the Irbesartan in Heart Failure with Preserved Ejection Fraction (IPRESERVE trial), hypertension was present among 91\% and obesity was present among $46 \%$ of women, with lower rates for both among men. Diabetes prevalence was similar between $\operatorname{sexes}^{298}$.

HFrEF can be classified as having an ischemic or non-ischemic etiology. Ischemic etiology is associated with epicardial CAD and/or MI and/or small vessel/microvascular disease. In the Framingham Heart Study, women accounted for $40 \%$ of the patients with HFrEF, compared to $65 \%$ of the patients with $\mathrm{HFpEF}^{299}$. This analysis found that $\mathrm{CAD}$ strongly favors the development of HFrEF (compared to HFpEF). Women are less likely to experience MI, which may contribute to the lower prevalence of women in the HFrEF population.

HFrEF from non-ischemic etiologies deserves special attention because of risk factors that are specific to women: pregnancy and cancer treatment for breast cancer. Peripartum cardiomyopathy (PPCM) presents as HFrEF late in a pregnancy, or soon after delivery. This condition affects about one in one thousand live births in the United States, with higher rates in other countries. The pathophysiology of PPCM is most likely different than other forms of HF and may be related oxidative-stress related cleavage of prolactin, a hormone unique to the pregnancy state, into a fragment that causes endothelial damage and myocardial dysfunction. Unique genetic variants may play a role, as well ${ }^{300}$. Still, as with HFpEF, hypertension may be associated with $\mathrm{PPCM}^{301}$. 
Breast cancer is the most common cancer among women and the treatment is associated with cardiomyopathy, with or without HF symptoms. Broadly, chemotherapy toxicity can be grouped as type I, irreversible damage most often caused by anthracyclines, or type II, potentially reversible toxicity ${ }^{302}$. Many breast cancer-specific treatments fall into one of these categories. Anthracyclines are type I agents that are often used to treat breast cancer, and are associated with left ventricular dysfunction in a cumulative dose dependent fashion. At higher doses ( $\geq 700 \mathrm{mg} / \mathrm{m}^{2}$ of doxorubicin), HF incidence may be as high as $18 \%$. Trastuzumab, a type II agent, is used to treat HER2 positive breast cancer, but has crossreactivity with HER 2 receptors in the heart ${ }^{303}$. Using administrative billing data to identify $\mathrm{HF}$, Bowles et al. found a four-fold increase in incident HF among women treated with trastuzumab alone, and a seven-fold increase in incident HF among women treated with doxorubicin plus trastuzumab ${ }^{304}$.

\subsubsection{Diagnosis}

Guideline based diagnosis and therapy in HF does not differ between women and men. Gender specific comorbidities and living conditions should be assessed, e.g. history of inflammatory or psychiatric diseases, malignancies, depression and other potentially related comorbidities, stress, socioeconomic and working conditions, gynecological and andrological history with number of children, still births, sexual activity and hormone therapy 305,306 . Women exhibit a worse quality of life after diagnosis of HF and exhibit depression more frequently. Because of the high prevalence of depression in women with HF, systematic screening may be considered ${ }^{305}$.

Clinical investigation and echocardiography are the gold standards. When assessing ventricular size in HFrEF, care should be taken to normalize ventricular diameters and ventricular diameters to body size. This is not trivial and different normalization algorithms may lead to different results ${ }^{307}$. It has been documented that HF diagnosis was less frequently based on objective diagnostic tests in women than in $\operatorname{men}^{305}$. In the Euro Heart Survey echocardiography was used less frequently in women than in men, even in patients with identical clinical indications. Physicians should be informed about this potential bias in order to reduce it.

\subsubsection{Treatment}

4.1.3.1 HFrEF-HF treatment has been more successful in HFrEF, compared to HFpEF. The mainstays of HFrEF treatment include BBs and ACE-Is. Five randomized-controlled trials have compared BBs to placebo among patients with HFrEF, including metoprolol, carvedilol, bisoprolol, bucindolol, and nebivolol. Roughly one-fifth of participants in these trials were women, with the exception of the nebivolol trial (37\%), a reflection of the older age inclusion criteria. The carvedilol and metoprolol trials both included subgroup analyses, with non-significant interactions between sex and treatment effect. In addition, a metaanalysis of the beta-blocker trials suggested a similar mortality benefit for men and women with $\mathrm{HFrEF}^{308}$. Seven randomized clinical trials have compared ACE-Is to placebo among patients with HFrEF. Similar to beta-blockers, the proportion of women included in these trials was low, ranging from $7 \%$ in the enalapril prevention trial to $28 \%$ in the trandolapril trial. Several of the original trial results did not include subgroup analyses, but a subsequent 
meta-analysis suggested similar mortality benefit in men and women: the relative risk of mortality was [RR=0.82 (95\% CI:: 0.74 to 0.90$)]$ for men and [RR=0.92 (95\% CI: 0.81 to 1.04)] for women.

Like BBs and ACE-Is, aldosterone receptor antagonists also have mortality benefit among patients with HFrEF. Spironolactone and eplerenone have been tested in randomized placebo controlled trials, and both included subgroup analyses. While the proportion of women included was small, non-significant interaction terms between treatment effect and sex suggest similar efficacy among women.

Digoxin and chronic resynchronization therapy (CRT) may have more sex-specific efficacy compared to BBs, ACE-Is, or ARBs. The original digoxin trial demonstrated lack of mortality benefit in HFrEF and subsequent analyses suggested an increased mortality among women. A post-hoc analysis found that death from any cause was 5.8\% higher in women, and digoxin was associated with a higher rate of death in women, but not in men. While these findings may have been due to higher drug levels in women ${ }^{309}$, the results are still alarming and highlight the need for sex-specific attention to medical treatment. CRT, on the other hand, may have greater efficacy in women compared to men with HFrEF. One study used a large, observational registry of over 75,000 patients to examine mortality differences among men and women with CRT-defibrillator versus defibrillator alone. Among patients with a left-bundle branch block (LBBB), women with CRT-defibrillator compared to defibrillator alone had a more pronounced mortality benefit than men [(HR 0.74 in women versus HR 0.84 in men, with a significant sex-efficacy interaction $(\mathrm{p}=0.025)]^{310}$.

Subsequently, the Food and Drug Administration undertook a patient-level pooled analysis to address the same question. The study included data from three clinical trials and, again, showed significantly greater mortality benefit among women with LBBB compared to men, despite the small number of women included in the CRT clinical trials ${ }^{311}$. On the heels of these results, Biotronik has launched the Biowomen trial—which may be the first HF trial that explicitly aims to enroll equal numbers of men and women-to examine sex-specific response to CRT treatment ${ }^{312}$.

Only one randomized-controlled trial for treatment of peripartum cardiomyopathy has been published to date. In this study of 21 women randomized to bromocriptine had greater recovery of left ventricular ejection fraction at six months, as well as a lower rate of the composite end point defined as death, New York Heart Association (NYHA) functional class $\mathrm{III} / \mathrm{IV}$, or left ventricular ejection fraction $<35 \%$ at 6 months $^{313}$. A larger trial of bromocriptine treatment has been completed and the results are forthcoming 314 .

4.1.3.2 HFpEF-Clinical trial data to support the treatment of HFpEF, the predominant form of HF among women, are scarce and generally neutral. While beta-blockers are a key part of HFrEF treatment, the same is not true for HFpEF. A small trial from Sweden randomized 113 patients with $\mathrm{HFpEF}$ ( $\mathrm{EF} \geq 45 \%$ ) to carvedilol or placebo. The primary outcome of the trial was echocardiography-based diastolic function parameters and carvedilol treated patients had improved estimated left-sided filling pressures ${ }^{315}$. A registry based study, however, found no clinical benefit (defined as mortality and hospitalization) for beta-blockers among patients with $\mathrm{HFpEF}^{316}$. One clinical trial tested an ACE inhibitor, 
perindopril, against placebo among older patients with HFpEF. Low enrolment and high cross over, however, limit the utility of this negative trial ${ }^{317}$. Finally, a randomized placebo controlled trial failed to show a benefit of spironolactone over placebo among HFpEF patients $^{318}$.

\subsubsection{Outcome}

With comparable treatment, women with HF have better clinical outcomes than men ${ }^{305}$. This remains true even if HFrEF and HFpEF are analyzed separately. In most cases of HF due to inherited cardiomyopathies, women appear to do better, independent of therapy. Thus it has been suggested that women have more efficient compensatory mechanisms that may overcome an insult at the molecular or at cellular level.

Worldwide, fewer women than men undergo heart transplantation. In a large dataset of consecutive patients with idiopathic non-ischemic DCM referred for heart transplantation to the German Heart Institute only $15.6 \%$ were women, suggesting a referral bias against women $^{305,} 319$.

Women present more frequently in NYHA III-IV than men, have lower exercise tolerance, respiratory efficiency and kidney function. Women also have significantly less diabetes than men. Thus, women were referred at a more advanced disease state and relative contraindi cations such as diabetes appear to be taken more seriously in women. An international multicenter prospective study on referral for heart transplantation, organ allocation and survival appears mandatory.

\section{Conclusions and Future Research}

CVD remains the leading cause of morbidity and mortality in women, worldwide. To reduce the burden and improve outcomes in women, sex differences in diagnosis, treatment and outcomes must be explored and understood. This is an essential as we move towards the era of precision medicine. While significant progress has been made, as outlined in this review, much more needs to be done. At a minimum, more women need to be enrolled in clinical trials, and the results of those trials need to be reported by sex. While legislation in the US and policy recommendations in Canada and Europe are moving in that direction, policies to increase research into sex differences at the basic research level are also required to close the knowledge gap.

The social and psychosocial (gendered) reasons for the under-treatment of women require urgent attention. Greater engagement of women patients in the design, conduct of studies, as well as their input to guide knowledge translation and implementation deserves greater consideration. This may be particularly relevant in younger women, who have benefitted the least from the significant improvements in survival from CVD experienced by the rest of the population. Improved awareness among women and their healthcare providers regarding the burden of CVD and its implications for morbidity and mortality also needs to be addressed. Ideally, CVD risk factors should be reviewed at each encounter with a woman's healthcare provider. We encourage healthcare providers to increase their index of suspicion for heart disease when they encounter women with vague symptoms (e.g. atypical pain/discomfort, 
indigestion, extreme fatigue). We also encourage individuals, women's groups, heart health charities, colleges and universities, ethnic organizations, and the media, to increase awareness about heart disease among women.

Research areas that merit special attention include research into optimal methods to diagnose and treat coronary microvascular dysfunction; research to standardize the diagnosis of SCAD and to identify and test treatments for SCAD; and research to identify and evaluate efficacious treatments for HFpEF. There is also an urgent need to better understand women's risk over the lifespan, from menarche, to pregnancy, through menopause.

\section{Acknowledgments}

Funding Sources

Dr. Karin Humphries is supported by the UBC-Heart and Stroke Foundation (HSF) Professorship in Women's Cardiovascular Health. Dr. Viola Vaccarino is supported by the following grants: R01 HL109413, P01 HL101398, R21 HL093665, and 2K24 HL077506. For Dr. Bairey Merz, this work was supported by contracts from the National Heart, Lung and Blood Institutes nos. N01-HV-68161, N01-HV-68162, N01-HV-68163, N01-HV-68164, grants U0164829, U01 HL649141, U01 HL649241, K23HL105787, T32HL69751, R01 HL090957, 1R03AG032631 from the National Institute on Aging, GCRC grant MO1-RR00425 from the National Center for Research Resources, the National Center for Advancing Translational Sciences Grant UL1TR000124 and UL1TR000064, and grants from the Gustavus and Louis Pfeiffer Research Foundation, Danville, NJ, The Women's Guild of Cedars-Sinai Medical Center, Los Angeles, CA, The Ladies Hospital Aid Society of Western Pennsylvania, Pittsburgh, PA, and QMED, Inc., Laurence Harbor, NJ, the Edythe L. Broad and the Constance Austin Women's Heart Research Fellowships, Cedars-Sinai Medical Center, Los Angeles, California, the Barbra Streisand Women's Cardiovascular Research and Education Program, Cedars-Sinai Medical Center, Los Angeles, The Society for Women's Health Research (SWHR), Washington, D.C., The Linda Joy Pollin Women's Heart Health Program, and the Erika Glazer Women's Heart Health Project, Cedars-Sinai Medical Center, Los Angeles, California.

\section{Abbreviations and Acronyms}

ACE-I Angiotensin Converting Enzyme Inhibitor

ARB Angiotensin Receptor Blocker

BB Beta Blocker

CABG Coronary Artery Bypass Grafting

CBF Coronary Blood Flow

CFR Coronary Flow Reserve

CHD Coronary Heart Disease

CIHI Canadian Institutes for Health

CMD Coronary Microvascular Dysfunction

CMRI Cardiac Magnetic Resonance Imaging

CRT Chronic Resynchronization Therapy

CS Coronary Vasospasm 


\begin{tabular}{|c|c|}
\hline GDM & Gestational Diabetes \\
\hline HF & Heart Failure \\
\hline HFpEF & HF with preserved ejection fraction \\
\hline HFrEF & HF with reduced ejection fraction \\
\hline ICH & Intra-Cranial Haemorrhage \\
\hline ICRT & Invasive Coronary Reactivity Testing \\
\hline IVUS & Intravascular Ultrasound \\
\hline MACE & Major Adverse Cardiac Events \\
\hline MPRI & Myocardial Perfusion Reserve Index \\
\hline NSTEMI & Non-ST-Elevation Myocardial Infarction \\
\hline OR & Odds Ratio \\
\hline PCI & Percutaneous coronary intervention \\
\hline PTP & Patient's Pre-test Probability \\
\hline QoL & Quality of Life \\
\hline $\mathbf{R R}$ & Relative Risk \\
\hline SAQ & Seattle Angina Questionnaire \\
\hline SIHD & Stable Ischemic Heart Disease \\
\hline SCAD & Spontaneous Coronary Artery Dissection \\
\hline SES & Socioeconomic Status \\
\hline SMR & Standardized Mortality Ratio \\
\hline STEMI & ST-Elevation Myocardial Infarction \\
\hline TCAs & Tricyclic Anti-depressants \\
\hline TCFA & Thin Cap Fibroatheroma \\
\hline TTS & Takotsubo's Syndrome \\
\hline WHO & World Health Organization \\
\hline WISE & Women's Ischemic Syndrome Evaluation \\
\hline
\end{tabular}

\section{References}

1. Wizemann, TM., Pardue, ML. Exploring the Biological Contributions to Human Health: Does Sex Matter?. Washington (DC): 2001.

Front Neuroendocrinol. Author manuscript; available in PMC 2018 July 01. 
2. United States Government Publishing Office. Inclusion of women and minorities in clinical research. Retrieved from https://www.gpo.gov/fdsys/pkg/USCODE-2011-title42/pdf/ USCODE-2011-title42-chap6A-subchapIII-partH-sec289a-2.pdf Accessed on Nov 24, 2016

3. Canadian Institutes of Health Research. Sex, Gender and Health Research. Retrieved from http:// www.cihr-irsc.gc.ca/e/22630.html-1-A2 Accessed on Nov 24, 2016

4. Stolarz AJ, Rusch NJ. Gender Differences in Cardiovascular Drugs. Cardiovascular drugs and therapy. 2015; 29:403-10. [PubMed: 26227895]

5. Hofer-Dueckelmann C, Prinz E, Beindl W, Szymanski J, Fellhofer G, Pichler M, Schuler J. Adverse drug reactions (ADRs) associated with hospital admissions -elderly female patients are at highest risk. International journal of clinical pharmacology and therapeutics. 2011; 49:577-86. [PubMed: 21961482]

6. Anand SS, Islam S, Rosengren A, Franzosi MG, Steyn K, Yusufali AH, Keltai M, Diaz R, Rangarajan S, Yusuf S. Risk factors for myocardial infarction in women and men: insights from the INTERHEART study. Eur Heart J. 2008; 29:932-40. [PubMed: 18334475]

7. Yusuf S, Hawken S, Ounpuu S, Dans T, Avezum A, Lanas F, McQueen M, Budaj A, Pais P, Varigos J, Lisheng L. Effect of potentially modifiable risk factors associated with myocardial infarction in 52 countries (the INTERHEART study): case-control study. Lancet. 2004; 364:937-52. [PubMed: 15364185]

8. Vaccarino V, Badimon L, Corti R, de Wit C, Dorobantu M, Hall A, Koller A, Marzilli M, Pries A, Bugiardini R, Working Group on Coronary P and Microcirculation. Ischaemic heart disease in women: are there sex differences in pathophysiology and risk factors? Position paper from the working group on coronary pathophysiology and microcirculation of the European Society of Cardiology. Cardiovasc Res. 2011; 90:9-17. [PubMed: 21159671]

9. Appelman Y, van Rijn BB, Ten Haaf ME, Boersma E, Peters SA. Sex differences in cardiovascular risk factors and disease prevention. Atherosclerosis. 2015; 241:211-8. [PubMed: 25670232]

10. World Health Organization. Global Report WHO on Diabetes. 2016. Retrieved from http:// apps.who.int/iris/bitstream/10665/204871/1/9789241565257_eng.pdf Accessed on Dec 12, 2016.

11. Statistics Canada. Diabetes, 2014. 2014. Retrieved from http://www.statcan.gc.ca/pub/82-625-x/ 2015001/article/14180-eng.htm Accessed on Dec 12, 2016

12. National Center for Chronic Disease Prevention and Health Promotion. National Diabetes Statistics Report, 2014. 2014. Retrieved from http://www.cdc.gov/diabetes/pdfs/data/2014-report-estimatesof-diabetes-and-its-burden-in-the-united-states.pdf Accessed on January 17, 2017

13. Wilson, PWF., Kannel, WB. Epidemiology of hyperglycemia and atherosclerosis Diabetes and Vascular Disease. New York, NY: Oxford University Press; 1992. p. 21-29.

14. Barrett-Connor E, Giardina EG, Gitt AK, Gudat U, Steinberg HO, Tschoepe D. Women and heart disease: the role of diabetes and hyperglycemia. Arch Intern Med. 2004; 164:934-42. [PubMed: 15136300]

15. Peters SA, Huxley RR, Woodward M. Diabetes as risk factor for incident coronary heart disease in women compared with men: a systematic review and meta-analysis of 64 cohorts including 858,507 individuals and 28,203 coronary events. Diabetologia. 2014; 57:1542-51. [PubMed: 24859435]

16. Huxley RR, Peters SA, Mishra GD, Woodward M. Risk of all-cause mortality and vascular events in women versus men with type 1 diabetes: a systematic review and meta-analysis. Lancet Diabetes Endocrinol. 2015; 3:198-206. [PubMed: 25660575]

17. Wannamethee SG, Papacosta O, Lawlor DA, Whincup PH, Lowe GD, Ebrahim S, Sattar N. Do women exhibit greater differences in established and novel risk factors between diabetes and nondiabetes than men? The British Regional Heart Study and British Women's Heart Health Study. Diabetologia. 2012; 55:80-7. [PubMed: 21861177]

18. Peters SA, Huxley RR, Woodward M. Diabetes as a risk factor for stroke in women compared with men: a systematic review and meta-analysis of 64 cohorts, including 775,385 individuals and 12,539 strokes. Lancet. 2014; 383:1973-80. [PubMed: 24613026]

19. Wexler DJ, Grant RW, Meigs JB, Nathan DM, Cagliero E. Sex disparities in treatment of cardiac risk factors in patients with type 2 diabetes. Diabetes Care. 2005; 28:514-20. [PubMed: 15735180] 
20. Collins R, Armitage J, Parish S, Sleigh P, Peto R, Heart Protection Study Collaborative G. MRC/BHF Heart Protection Study of cholesterol-lowering with simvastatin in 5963 people with diabetes: a randomised placebo-controlled trial. Lancet. 2003; 361:2005-16. [PubMed: 12814710]

21. Tang M, Chen Y, Krewski D. Gender-related differences in the association between socioeconomic status and self-reported diabetes. Int J Epidemiol. 2003; 32:381-5. [PubMed: 12777423]

22. Schnohr C, Hojbjerre L, Riegels M, Ledet L, Larsen T, Schultz-Larsen K, Petersen L, Prescott E, Gronbaek M. Does educational level influence the effects of smoking, alcohol, physical activity, and obesity on mortality? A prospective population study. Scand J Public Health. 2004; 32:250-6. [PubMed: 15370764]

23. Dumith SC, Hallal PC, Reis RS, Kohl HW 3rd. Worldwide prevalence of physical inactivity and its association with human development index in 76 countries. Prev Med. 2011; 53:24-8. [PubMed: 21371494]

24. Organization WH. Physical Activity and Women. Retrieved from http://www.who.int/ dietphysicalactivity/factsheet_women/en/ March 23, 2017

25. Puymirat E, Simon T, Steg PG, Schiele F, Gueret P, Blanchard D, Khalife K, Goldstein P, Cattan S, Vaur L, Cambou JP, Ferrieres J, Danchin N. Association of changes in clinical characteristics and management with improvement in survival among patients with ST-elevation myocardial infarction. Jama. 2012; 308:998-1006. [PubMed: 22928184]

26. Kannel WB, McGee DL, Castelli WP. Latest perspectives on cigarette smoking and cardiovascular disease: the Framingham Study. Journal of cardiopulmonary rehabilitation. 1984:267-277.

27. Oliveira A, Barros H, Maciel MJ, Lopes C. Tobacco smoking and acute myocardial infarction in young adults: a population-based case-control study. Prev Med. 2007; 44:311-6. [PubMed: 17239433]

28. Prescott E, Hippe M, Schnohr P, Hein HO, Vestbo J. Smoking and risk of myocardial infarction in women and men: longitudinal population study. Bmj. 1998; 316:1043-7. [PubMed: 9552903]

29. Farley TM, Meirik O, Chang CL, Poulter NR. Combined oral contraceptives, smoking, and cardiovascular risk. J Epidemiol Community Health. 1998; 52:775-85. [PubMed: 10396518]

30. Salonen JT. Oral contraceptives, smoking and risk of myocardial infarction in young women. A longitudinal population study in eastern Finland. Acta Med Scand. 1982; 212:141-4. [PubMed: 7148505]

31. Njolstad I, Arnesen E, Lund-Larsen PG. Smoking, serum lipids, blood pressure, and sex differences in myocardial infarction. A 12-year follow-up of the Finnmark Study. Circulation. 1996; 93:450-6. [PubMed: 8565161]

32. Allen AM, Oncken C, Hatsukami D. Women and Smoking: The Effect of Gender on the Epidemiology, Health Effects, and Cessation of Smoking. Curr Addict Rep. 2014; 1:53-60. [PubMed: 27213132]

33. Cupisti S, Haberle L, Dittrich R, Oppelt PG, Reissmann C, Kronawitter D, Beckmann MW, Mueller A. Smoking is associated with increased free testosterone and fasting insulin levels in women with polycystic ovary syndrome, resulting in aggravated insulin resistance. Fertil Steril. 2010; 94:673-7. [PubMed: 19394003]

34. Guaderrama MM, Corwin EJ, Kapelewski CH, Klein LC. Sex differences in effects of cigarette smoking and 24-hr abstinence on plasma arginine vasopressin. Addict Behav. 2011; 36:1106-9. [PubMed: 21752550]

35. Steptoe A, Kivimaki M. Stress and cardiovascular disease: an update on current knowledge. Annual review of public health. 2013; 34:337-54.

36. Vaccarino, V. Psychosocial Risk Factors for Heart Disease in Women, With Special Reference to Early Life Stress, Depression and Posttraumatic Stress Disorder. In: Orth-Gomer, K.Vaccarino, V.Schneiderman, N., Deter, HC., editors. Psychosocial Stress and Cardiovascular Disease in Women: Concepts, Findings and Future Perspectives. Switzerland: Springer International Publishing; 2015.

37. Yusuf S, Hawken S, Ounpuu S, Dans T, Avezum A, Lanas F, McQueen M, Budaj A, Pais P, Varigos J. Effect of potentially modifiable risk factors associated with myocardial infarction in 52 countries (the INTERHEART study): case-control study. Lancet. 2004; 364:937-952. [PubMed: 15364185] 
38. Vaccarino, V., Bremner, JD. Psychiatric and behavioral aspects of cardiovascular disease. In: Mann, DL.Zipes, DP.Libby, P., Bonow, RO., editors. Braunwald's Heart Disease -A Textbook of Cardiovascular Medicine. 10th. Philadelphia, PA: Elsevier-Saunders; 2015.

39. Handberg EM, Eastwood JA, Eteiba W, Johnson BD, Krantz DS, Thompson DV, Vaccarino V, Bittner V, Sopko G, Pepine CJ, Merz NB, Rutledge TR. Clinical implications of the Women's Ischemia Syndrome Evaluation: inter-relationships between symptoms, psychosocial factors and cardiovascular outcomes. Womens Health (Lond). 2013; 9:479-90. [PubMed: 24007253]

40. Vaccarino V, Bremner JD. Behavioral, Emotional and Neurobiological Determinants of Coronary Heart Disease Risk in Women. Neurosci Biobehav Rev. 2016

41. Substance Abuse and Mental Health Services Administration. Results from the 2011 National Survey on Drug Use and Health: Mental Health Findings. 2012:12-4725.NSDUH Series H-45, HHS Publication No. (SMA)

42. Mallik S, Spertus JA, Reid KJ, Krumholz HM, Rumsfeld JS, Weintraub WS, Agarwal P, Santra M, Bidyasar S, Lichtman JH, Wenger NK, Vaccarino V. Depressive symptoms after acute myocardial infarction: evidence for highest rates in younger women. Arch Intern Med. 2006; 166:876-83. [PubMed: 16636213]

43. Vaccarino V, Shah AJ, Rooks C, Ibeanu I, Nye JA, Pimple P, Salerno A, D’Marco L, Karohl C, Bremner JD, Raggi P. Sex differences in mental stress-induced myocardial ischemia in young survivors of an acute myocardial infarction. Psychosom Med. 2014; 76:171-80. [PubMed: 24608039]

44. Smolderen KG, Strait KM, Dreyer RP, D’Onofrio G, Zhou S, Lichtman JH, Geda M, Bueno H, Beltrame J, Safdar B, Krumholz HM, Spertus JA. Depressive symptoms in younger women and men with acute myocardial infarction: insights from the VIRGO study. Journal of the American Heart Association. 2015; 4doi: 10.1161/JAHA.114.001424

45. Lichtman JH, Froelicher ES, Blumenthal JA, Carney RM, Doering LV, Frasure-Smith N, Freedland KE, Jaffe AS, Leifheit-Limson EC, Sheps DS, Vaccarino V, Wulsin L, American Heart Association Statistics Committee of the Council on Epidemiology and Prevention and the Council on Cardiovascular and Stroke Nursing. Depression as a risk factor for poor prognosis among patients with acute coronary syndrome: systematic review and recommendations: a scientific statement from the American Heart Association. Circulation. 2014; 129:1350-69. [PubMed: 24566200]

46. Carney RM, Freedland KE. Depression and coronary heart disease. Nat Rev Cardiol. 2016

47. Wassertheil-Smoller S, Shumaker S, Ockene J, Talavera GA, Greenland P, Cochrane B, Robbins J, Aragaki A, Dunbar-Jacob J. Depression and Cardiovascular Sequelae in Postmenopausal Women: The Women's Health Initiative (WHI). Archives of Internal Medicine. 2004; 164:289-298. [PubMed: 14769624]

48. Whang W, Kubzansky LD, Kawachi I, Rexrode KM, Kroenke CH, Glynn RJ, Garan H, Albert CM. Depression and risk of sudden cardiac death and coronary heart disease in women: results from the Nurses' Health Study. Journal of the American College of Cardiology. 2009; 53:950-958. [PubMed: 19281925]

49. Shah AJ, Veledar E, Hong Y, Bremner JD, Vaccarino V. Depression and history of attempted suicide as risk factors for heart disease mortality in young individuals. Archives of General Psychiatry. 2011; 68:1135-42. [PubMed: 22065529]

50. Wyman L, Crum RM, Celentano D. Depressed mood and cause-specific mortality: a 40-year general community assessment. Annals of epidemiology. 2012; 22:638-43. [PubMed: 22835415]

51. Shah AJ, Ghasemzadeh N, Zaragoza-Macias E, Patel R, Eapen DJ, Neeland IJ, Pimple PM, Zafari AM, Quyyumi AA, Vaccarino V. Sex and age differences in the association of depression with obstructive coronary artery disease and adverse cardiovascular events. J Am Heart Assoc. 2014; 3

52. Parashar S, Rumsfeld JS, Reid KJ, Buchanan D, Dawood N, Khizer S, Lichtman J, Vaccarino V, Investigators PR. Impact of depression on sex differences in outcome after myocardial infarction. Circulation Cardiovascular quality and outcomes. 2009; 2:33-40. [PubMed: 20031810]

53. Wegman HL, Stetler C. A meta-analytic review of the effects of childhood abuse on medical outcomes in adulthood. Psychosomatic Medicine. 2009; 71:805-812. [PubMed: 19779142]

Front Neuroendocrinol. Author manuscript; available in PMC 2018 July 01. 
54. Rich-Edwards JW, Mason S, Rexrode K, Spiegelman D, Hibert E, Kawachi I, Jun HJ, Wright RJ. Physical and sexual abuse in childhood as predictors of early-onset cardiovascular events in women. Circulation. 2012; 126:920-7. [PubMed: 22787111]

55. Batten SV, Aslan M, Maciejewski PK, Mazure CM. Childhood maltreatment as a risk factor for adult cardiovascular disease and depression. Journal of Clinical Psychiatry. 2004; 65:249-254. [PubMed: 15003081]

56. Korkeila J, Vahtera J, Korkeila K, Kivimaki M, Sumanen M, Koskenvuo K, Koskenvuo M. Childhood adversities as predictors of incident coronary heart disease and cerebrovascular disease. Heart. 2010; 96:298-303. [PubMed: 20194205]

57. Goodwin RD, Stein MB. Association between childhood trauma and physical disorders among adults in the United States. Psychological medicine. 2004; 34:509-20. [PubMed: 15259836]

58. Roest AM, Martens EJ, de Jonge P, Denollet J. Anxiety and risk of incident coronary heart disease: a meta-analysis. Journal of the American College of Cardiology. 2010; 56:38-46. [PubMed: 20620715]

59. Edmondson D, Kronish IM, Shaffer JA, Falzon L, Burg MM. Posttraumatic stress disorder and risk for coronary heart disease: a meta-analytic review. Am Heart J. 2013; 166:806-14. [PubMed: 24176435]

60. National Comorbidity Survey. NCS-R appendix tables: Table 1. Lifetime prevalence of DSM-IV/ WMH-CIDI disorders by sex and cohort. Table 2. Twelve-month prevalence of DSM-IV/WMHCIDI disorders by sex and cohort. 2005. Retrieved from http://www.hcp.med.harvard.edu/ncs/ publications.php Accessed on January 17, 2017

61. Kubzansky LD, Koenen KC, Jones C, Eaton WW. A prospective study of posttraumatic stress disorder symptoms and coronary heart disease in women. Health Psychology. 2009; 28:125-30. [PubMed: 19210026]

62. Sumner JA, Kubzansky LD, Elkind MS, Roberts AL, Agnew-Blais J, Chen Q, Cerda M, Rexrode KM, Rich-Edwards JW, Spiegelman D, Suglia SF, Rimm EB, Koenen KC. Trauma Exposure and Posttraumatic Stress Disorder Symptoms Predict Onset of Cardiovascular Events in Women. Circulation. 2015; 132:251-9. [PubMed: 26124186]

63. Bhattacharyya MR, Steptoe A. Emotional triggers of acute coronary syndromes: strength of evidence, biological processes, and clinical implications. Progress in cardiovascular diseases. 2007; 49:353-65. [PubMed: 17329181]

64. Mostofsky E, Maclure M, Tofler GH, Muller JE, Mittleman MA. Relation of outbursts of anger and risk of acute myocardial infarction. Am J Cardiol. 2013; 112:343-8. [PubMed: 23642509]

65. Mostofsky E, Maclure M, Sherwood JB, Tofler GH, Muller JE, Mittleman MA. Risk of acute myocardial infarction after the death of a significant person in one's life: the Determinants of Myocardial Infarction Onset Study. Circulation. 2012; 125:491-6. [PubMed: 22230481]

66. Wei J, Rooks C, Ramadan R, Shah AJ, Bremner JD, Quyyumi AA, Kutner M, Vaccarino V. Metaanalysis of mental stress-induced myocardial ischemia and subsequent cardiac events in patients with coronary artery disease. Am J Cardiol. 2014; 114:187-92. [PubMed: 24856319]

67. Samad Z, Boyle S, Ersboll M, Vora AN, Zhang Y, Becker RC, Williams R, Kuhn C, Ortel TL, Rogers JG, O'Connor CM, Velazquez EJ, Jiang W, Investigators R. Sex Differences in Platelet Reactivity and Cardiovascular and Psychological Response to Mental Stress in Patients With Stable Ischemic Heart Disease: Insights From the REMIT Study. J Am Coll Cardiol. 2014; 64:1669-78. [PubMed: 25323254]

68. Vaccarino V, Wilmot K, Al Mheid I, Ramadan R, Pimple P, Shah AJ, Garcia EV, Nye J, Ward L, Hammadah M, Kutner M, Long Q, Bremner JD, Esteves F, Raggi P, Quyyumi AA. Sex Differences in Mental Stress-Induced Myocardial Ischemia in Patients With Coronary Heart Disease. J Am Heart Assoc. 2016; 5

69. Pepine CJ, Petersen JW, Bairey Merz CN. A microvascular-myocardial diastolic dysfunctional state and risk for mental stress ischemia: a revised concept of ischemia during daily life. JACC Cardiovascular Imaging. 2014; 7:362-5. [PubMed: 24742891]

70. Kop WJ, Krantz DS, Howell RH, Ferguson MA, Papademetriou V, Lu D, Popma JJ, Quigley JF, Vernalis M, Gottdiener JS. Effects of mental stress on coronary epicardial vasomotion and flow 
velocity in coronary artery disease: relationship with hemodynamic stress responses. J Am Coll Cardiol. 2001; 37:1359-66. [PubMed: 11300447]

71. Ghiadoni L, Donald AE, Cropley M, Mullen MJ, Oakley G, Taylor M, O’Connor G, Betteridge J, Klein N, Steptoe A, Deanfield JE. Mental Stress Induces Transient Endothelial Dysfunction in Humans. Circulation. 2000; 102:2473-2478. [PubMed: 11076819]

72. Ramadan R, Sheps D, Esteves F, Zafari AM, Bremner JD, Vaccarino V, Quyyumi AA. Myocardial ischemia during mental stress: role of coronary artery disease burden and vasomotion. Journal of the American Heart Association. 2013; 2:e000321. [PubMed: 24145741]

73. Burg MM, Graeber B, Vashist A, Collins D, Earley C, Liu J, Lampert R, Soufer R. Noninvasive detection of risk for emotion-provoked myocardial ischemia. Psychosomatic Medicine. 2009; 71:14-20. [PubMed: 18941131]

74. Martin EA, Tan SL, MacBride LR, Lavi S, Lerman LO, Lerman A. Sex differences in vascular and endothelial responses to acute mental stress. Clin Auton Res. 2008; 18:339-45. [PubMed: 18850310]

75. Rooks CR, Ibeanu I, Shah A, Pimple P, Murrah N, Shallenberger L, Pace T, Douglas Bremner J, Raggi P, Vaccarino V. Young women post-MI have higher plasma concentrations of interleukin-6 before and after stress testing. Brain Behav Immun. 2016; 51:92-8. [PubMed: 26263552]

76. Mosca L, Benjamin EJ, Berra K, Bezanson JL, Dolor RJ, Lloyd-Jones DM, Newby LK, Pina IL, Roger VL, Shaw LJ, Zhao D, Beckie TM, Bushnell C, D’Armiento J, Kris-Etherton PM, Fang J, Ganiats TG, Gomes AS, Gracia CR, Haan CK, Jackson EA, Judelson DR, Kelepouris E, Lavie CJ, Moore A, Nussmeier NA, Ofili E, Oparil S, Ouyang P, Pinn VW, Sherif K, Smith SC Jr, Sopko G, Chandra-Strobos N, Urbina EM, Vaccarino V, Wenger NK, American Heart A. Effectivenessbased guidelines for the prevention of cardiovascular disease in women-2011 update: a guideline from the American Heart Association. J Am Coll Cardiol. 2011; 57:1404-23. [PubMed: 21388771]

77. Mehta PK, Minissian M, Bairey Merz CN. Adverse pregnancy outcomes and cardiovascular risk factor management. Semin Perinatol. 2015; 39:268-75. [PubMed: 26159741]

78. Magnussen EB, Vatten LJ, Smith GD, Romundstad PR. Hypertensive disorders in pregnancy and subsequently measured cardiovascular risk factors. Obstet Gynecol. 2009; 114:961-70. [PubMed: 20168095]

79. Bellamy L, Casas JP, Hingorani AD, Williams DJ. Pre-eclampsia and risk of cardiovascular disease and cancer in later life: systematic review and meta-analysis. Bmj. 2007; 335:974. [PubMed: 17975258]

80. Templin C, Ghadri JR, Diekmann J, Napp LC, Bataiosu DR, Jaguszewski M, Cammann VL, Sarcon A, Geyer V, Neumann CA, Seifert B, Hellermann J, Schwyzer M, Eisenhardt K, Jenewein J, Franke J, Katus HA, Burgdorf C, Schunkert H, Moeller C, Thiele H, Bauersachs J, Tschope C, Schultheiss HP, Laney CA, Rajan L, Michels G, Pfister R, Ukena C, Bohm M, Erbel R, Cuneo A, Kuck KH, Jacobshagen C, Hasenfuss G, Karakas M, Koenig W, Rottbauer W, Said SM, BraunDullaeus RC, Cuculi F, Banning A, Fischer TA, Vasankari T, Airaksinen KE, Fijalkowski M, Rynkiewicz A, Pawlak M, Opolski G, Dworakowski R, MacCarthy P, Kaiser C, Osswald S, Galiuto L, Crea F, Dichtl W, Franz WM, Empen K, Felix SB, Delmas C, Lairez O, Erne P, Bax JJ, Ford I, Ruschitzka F, Prasad A, Luscher TF. Clinical Features and Outcomes of Takotsubo (Stress) Cardiomyopathy. The New England journal of medicine. 2015; 373:929-38. [PubMed: 26332547]

81. Heida KY, Franx A, van Rijn BB, Eijkemans MJ, Boer JM, Verschuren MW, Oudijk MA, Bots ML, van der Schouw YT. Earlier Age of Onset of Chronic Hypertension and Type 2 Diabetes Mellitus After a Hypertensive Disorder of Pregnancy or Gestational Diabetes Mellitus. Hypertension. 2015; 66:1116-22. [PubMed: 26459420]

82. Ahmed R, Dunford J, Mehran R, Robson S, Kunadian V. Pre-eclampsia and future cardiovascular risk among women: a review. J Am Coll Cardiol. 2014; 63:1815-22. [PubMed: 24613324]

83. Mannisto T, Mendola P, Vaarasmaki M, Jarvelin MR, Hartikainen AL, Pouta A, Suvanto E. Elevated blood pressure in pregnancy and subsequent chronic disease risk. Circulation. 2013; 127:681-90. [PubMed: 23401113]

84. McDonald SD, Malinowski A, Zhou Q, Yusuf S, Devereaux PJ. Cardiovascular sequelae of preeclampsia/eclampsia: a systematic review and meta-analyses. Am Heart J. 2008; 156:918-30. [PubMed: 19061708] 
85. Fraser A, Nelson SM, Macdonald-Wallis C, Cherry L, Butler E, Sattar N, Lawlor DA. Associations of pregnancy complications with calculated cardiovascular disease risk and cardiovascular risk factors in middle age: the Avon Longitudinal Study of Parents and Children. Circulation. 2012; 125:1367-80. [PubMed: 22344039]

86. Hermes W, Franx A, van Pampus MG, Bloemenkamp KW, Bots ML, van der Post JA, Porath M, Ponjee GA, Tamsma JT, Mol BW, de Groot CJ. Cardiovascular risk factors in women who had hypertensive disorders late in pregnancy: a cohort study. Am J Obstet Gynecol. 2013; 208:474 e18. [PubMed: 23399350]

87. Smith GN, Pudwell J, Walker M, Wen SW. Ten-year, thirty-year, and lifetime cardiovascular disease risk estimates following a pregnancy complicated by preeclampsia. J Obstet Gynaecol Can. 2012; 34:830-5. [PubMed: 22971451]

88. Bytautiene E, Bulayeva N, Bhat G, Li L, Rosenblatt KP, Saade GR. Long-term alterations in maternal plasma proteome after sFlt1-induced preeclampsia in mice. Am J Obstet Gynecol. 2013; 208:388 e1-388 e10. [PubMed: 23497796]

89. Magnussen EB, Vatten LJ, Lund-Nilsen TI, Salvesen KA, Davey Smith G, Romundstad PR. Prepregnancy cardiovascular risk factors as predictors of pre-eclampsia: population based cohort study. Bmj. 2007; 335:978. [PubMed: 17975256]

90. Romundstad PR, Magnussen EB, Smith GD, Vatten LJ. Hypertension in pregnancy and later cardiovascular risk: common antecedents? Circulation. 2010; 122:579-84. [PubMed: 20660802]

91. Agatisa PK, Ness RB, Roberts JM, Costantino JP, Kuller LH, McLaughlin MK. Impairment of endothelial function in women with a history of preeclampsia: an indicator of cardiovascular risk. Am J Physiol Heart Circ Physiol. 2004; 286:H1389-93. [PubMed: 15020302]

92. Chambers JC, Fusi L, Malik IS, Haskard DO, De Swiet M, Kooner JS. Association of maternal endothelial dysfunction with preeclampsia. Jama. 2001; 285:1607-12. [PubMed: 11268269]

93. Lampinen KH, Ronnback M, Kaaja RJ, Groop PH. Impaired vascular dilatation in women with a history of pre-eclampsia. J Hypertens. 2006; 24:751-6. [PubMed: 16531805]

94. Hermes W, Ket JC, van Pampus MG, Franx A, Veenendaal MV, Kolster C, Tamsma JT, Bloemenkamp KW, Ponjee G, van der Hout E, Ten Horn H, Loix S, Mol BW, de Groot CJ. Biochemical cardiovascular risk factors after hypertensive pregnancy disorders: a systematic review and meta-analysis. Obstet Gynecol Surv. 2012; 67:793-809. [PubMed: 23233052]

95. Kaaja RJ, Greer IA. Manifestations of chronic disease during pregnancy. Jama. 2005; 294:2751-7. [PubMed: 16333011]

96. Kaaja RJ, Poyhonen-Alho MK. Insulin resistance and sympathetic overactivity in women. J Hypertens. 2006; 24:131-41. [PubMed: 16331111]

97. Stekkinger E, Zandstra M, Peeters LL, Spaanderman ME. Early-onset preeclampsia and the prevalence of postpartum metabolic syndrome. Obstet Gynecol. 2009; 114:1076-84. [PubMed: 20168110]

98. van Rijn BB, Nijdam ME, Bruinse HW, Roest M, Uiterwaal CS, Grobbee DE, Bots ML, Franx A. Cardiovascular disease risk factors in women with a history of early-onset preeclampsia. Obstet Gynecol. 2013; 121:1040-8. [PubMed: 23635741]

99. Yinon Y, Kingdom JC, Odutayo A, Moineddin R, Drewlo S, Lai V, Cherney DZ, Hladunewich MA. Vascular dysfunction in women with a history of preeclampsia and intrauterine growth restriction: insights into future vascular risk. Circulation. 2010; 122:1846-53. [PubMed: 20956209]

100. Zandstra M, Stekkinger E, van der Vlugt MJ, van Dijk AP, Lotgering FK, Spaanderman ME. Cardiac diastolic dysfunction and metabolic syndrome in young women after placental syndrome. Obstet Gynecol. 2010; 115:101-8. [PubMed: 20027041]

101. Bellamy L, Casas JP, Hingorani AD, Williams D. Type 2 diabetes mellitus after gestational diabetes: a systematic review and meta-analysis. Lancet. 2009; 373:1773-9. [PubMed: 19465232]

102. Carr DB, Utzschneider KM, Hull RL, Tong J, Wallace TM, Kodama K, Shofer JB, Heckbert SR, Boyko EJ, Fujimoto WY, Kahn SE. Gestational diabetes mellitus increases the risk of cardiovascular disease in women with a family history of type 2 diabetes. Diabetes Care. 2006; 29:2078-83. [PubMed: 16936156] 
103. Fadl H, Magnuson A, Ostlund I, Montgomery S, Hanson U, Schwarcz E. Gestational diabetes mellitus and later cardiovascular disease: a Swedish population based case-control study. BJOG. 2014; 121:1530-6. [PubMed: 24762194]

104. Kessous R, Shoham-Vardi I, Pariente G, Sherf M, Sheiner E. An association between gestational diabetes mellitus and long-term maternal cardiovascular morbidity. Heart. 2013; 99:1118-21. [PubMed: 23749791]

105. Shah BR, Retnakaran R, Booth GL. Increased risk of cardiovascular disease in young women following gestational diabetes mellitus. Diabetes Care. 2008; 31:1668-9. [PubMed: 18487472]

106. Retnakaran R, Shah BR. Mild glucose intolerance in pregnancy and risk of cardiovascular disease: a population-based cohort study. CMAJ. 2009; 181:371-6. [PubMed: 19703913]

107. Canoy D, Beral V, Balkwill A, Wright FL, Kroll ME, Reeves GK, Green J, Cairns BJ, Million Women Study C. Age at menarche and risks of coronary heart and other vascular diseases in a large UK cohort. Circulation. 2015; 131:237-44. [PubMed: 25512444]

108. Charalampopoulos D, McLoughlin A, Elks CE, Ong KK. Age at menarche and risks of all-cause and cardiovascular death: a systematic review and meta-analysis. Am J Epidemiol. 2014; 180:2940. [PubMed: 24920784]

109. Hu FB, Grodstein F, Hennekens CH, Colditz GA, Johnson M, Manson JE, Rosner B, Stampfer MJ. Age at natural menopause and risk of cardiovascular disease. Arch Intern Med. 1999; 159:1061-6. [PubMed: 10335682]

110. Mondul AM, Rodriguez C, Jacobs EJ, Calle EE. Age at natural menopause and cause-specific mortality. Am J Epidemiol. 2005; 162:1089-97. [PubMed: 16221806]

111. Muka T, Oliver-Williams C, Kunutsor S, Laven JS, Fauser BC, Chowdhury R, Kavousi M, Franco $\mathrm{OH}$. Association of Age at Onset of Menopause and Time Since Onset of Menopause With Cardiovascular Outcomes, Intermediate Vascular Traits, and All-Cause Mortality: A Systematic Review and Meta-analysis. JAMA Cardiol. 2016; 1:767-776. [PubMed: 27627190]

112. Howard BV, Kuller L, Langer R, Manson JE, Allen C, Assaf A, Cochrane BB, Larson JC, Lasser N, Rainford M, Van Horn L, Stefanick ML, Trevisan M, Women's Health I. Risk of cardiovascular disease by hysterectomy status, with and without oophorectomy: the Women's Health Initiative Observational Study. Circulation. 2005; 111:1462-70. [PubMed: 15781742]

113. Lerner DJ, Kannel WB. Patterns of coronary heart disease morbidity and mortality in the sexes: a 26-year follow-up of the Framingham population. Am Heart J. 1986; 111:383-90. [PubMed: 3946178]

114. Albrektsen G, Heuch I, Lochen ML, Thelle DS, Wilsgaard T, Njolstad I, Bonaa KH. Lifelong Gender Gap in Risk of Incident Myocardial Infarction: The Tromso Study. JAMA Intern Med. 2016; 176:1673-1679. [PubMed: 27617629]

115. Grady D, Herrington D, Bittner V, Blumenthal R, Davidson M, Hlatky M, Hsia J, Hulley S, Herd A, Khan S, Newby LK, Waters D, Vittinghoff E, Wenger N, Group HR. Cardiovascular disease outcomes during 6.8 years of hormone therapy: Heart and Estrogen/progestin Replacement Study follow-up (HERS II). Jama. 2002; 288:49-57. [PubMed: 12090862]

116. Hulley S, Grady D, Bush T, Furberg C, Herrington D, Riggs B, Vittinghoff E. Randomized trial of estrogen plus progestin for secondary prevention of coronary heart disease in postmenopausal women. Heart and Estrogen/progestin Replacement Study (HERS) Research Group. Jama. 1998; 280:605-13. [PubMed: 9718051]

117. Rossouw JE, Anderson GL, Prentice RL, LaCroix AZ, Kooperberg C, Stefanick ML, Jackson RD, Beresford SA, Howard BV, Johnson KC, Kotchen JM, Ockene J, Writing Group for the Women's Health Initiative I. Risks and benefits of estrogen plus progestin in healthy postmenopausal women: principal results From the Women's Health Initiative randomized controlled trial. Jama. 2002; 288:321-33. [PubMed: 12117397]

118. Camici PG, Crea F. Coronary microvascular dysfunction. The New England journal of medicine. 2007; 356:830-40. [PubMed: 17314342]

119. Thygesen K, Alpert JS, Jaffe AS, Simoons ML, Chaitman BR, White HD, Task Force for the Universal Definition of Myocardial I. Third universal definition of myocardial infarction. Nat Rev Cardiol. 2012; 9:620-33. [PubMed: 22922597] 
120. Jneid H, Fonarow GC, Cannon CP, Hernandez AF, Palacios IF, Maree AO, Wells Q, Bozkurt B, Labresh KA, Liang L, Hong Y, Newby LK, Fletcher G, Peterson E, Wexler L, Get With the Guidelines Steering $C$ and Investigators. Sex differences in medical care and early death after acute myocardial infarction. Circulation. 2008; 118:2803-10. [PubMed: 19064680]

121. Pelletier R, Humphries KH, Shimony A, Bacon SL, Lavoie KL, Rabi D, Karp I, Tsadok MA, Pilote L, Investigators G-P. Sex-related differences in access to care among patients with premature acute coronary syndrome. CMAJ. 2014; 186:497-504. [PubMed: 24638026]

122. Dey S, Flather MD, Devlin G, Brieger D, Gurfinkel EP, Steg PG, Fitzgerald G, Jackson EA, Eagle KA. Global Registry of Acute Coronary Events i. Sex-related differences in the presentation, treatment and outcomes among patients with acute coronary syndromes: the Global Registry of Acute Coronary Events. Heart. 2009; 95:20-6. [PubMed: 18463200]

123. Canto JG, Rogers WJ, Goldberg RJ, Peterson ED, Wenger NK, Vaccarino V, Kiefe CI, Frederick PD, Sopko G, Zheng ZJ, Investigators N. Association of age and sex with myocardial infarction symptom presentation and in-hospital mortality. Jama. 2012; 307:813-22. [PubMed: 22357832]

124. Pagidipati NJ, Peterson ED. Acute coronary syndromes in women and men. Nat Rev Cardiol. 2016; 13:471-80. [PubMed: 27256211]

125. Lansky AJ, Ng VG, Maehara A, Weisz G, Lerman A, Mintz GS, De Bruyne B, Farhat N, Niess G, Jankovic I, Lazar D, Xu K, Fahy M, Serruys PW, Stone GW. Gender and the extent of coronary atherosclerosis, plaque composition, and clinical outcomes in acute coronary syndromes. JACC Cardiovascular imaging. 2012; 5:S62-72. [PubMed: 22421232]

126. Mehta LS, Beckie TM, DeVon HA, Grines CL, Krumholz HM, Johnson MN, Lindley KJ, Vaccarino V, Wang TY, Watson KE, Wenger NK. Acute Myocardial Infarction in Women: A Scientific Statement From the American Heart Association. Circulation. 2016; 133:916-47. [PubMed: 26811316]

127. Schwartz RS, Burke A, Farb A, Kaye D, Lesser JR, Henry TD, Virmani R. Microemboli and microvascular obstruction in acute coronary thrombosis and sudden coronary death: relation to epicardial plaque histopathology. J Am Coll Cardiol. 2009; 54:2167-73. [PubMed: 19942088]

128. White SJ, Newby AC, Johnson TW. Endothelial erosion of plaques as a substrate for coronary thrombosis. Thrombosis and haemostasis. 2016; 115:509-19. [PubMed: 26791872]

129. Chandrasekhar J, Mehran R. Sex-Based Differences in Acute Coronary Syndromes: Insights From Invasive and Noninvasive Coronary Technologies. JACC Cardiovascular imaging. 2016; 9:451-64. [PubMed: 27056164]

130. Zaya M, Mehta PK, Merz CN. Provocative testing for coronary reactivity and spasm. J Am Coll Cardiol. 2014; 63:103-9. [PubMed: 24201078]

131. Kaski JC, Maseri A, Vejar M, Crea F, Hackett D. Spontaneous coronary artery spasm in variant angina is caused by a local hyperreactivity to a generalized constrictor stimulus. J Am Coll Cardiol. 1989; 14:1456-63. [PubMed: 2809004]

132. Amano M, Ito M, Kimura K, Fukata Y, Chihara K, Nakano T, Matsuura Y, Kaibuchi K. Phosphorylation and activation of myosin by Rho-associated kinase (Rho-kinase). The Journal of biological chemistry. 1996; 271:20246-9. [PubMed: 8702756]

133. Chataigneau T, Feletou M, Huang PL, Fishman MC, Duhault J, Vanhoutte PM. Acetylcholineinduced relaxation in blood vessels from endothelial nitric oxide synthase knockout mice. British journal of pharmacology. 1999; 126:219-26. [PubMed: 10051139]

134. Lanza GA, Careri G, Crea F. Mechanisms of coronary artery spasm. Circulation. 2011; 124:177482. [PubMed: 22007100]

135. Pope JH, Aufderheide TP, Ruthazer R, Woolard RH, Feldman JA, Beshansky JR, Griffith JL, Selker HP. Missed diagnoses of acute cardiac ischemia in the emergency department. The New England journal of medicine. 2000; 342:1163-70. [PubMed: 10770981]

136. Vaccarino V, Parsons L, Every NR, Barron HV, Krumholz HM. Sex-based differences in early mortality after myocardial infarction. National Registry of Myocardial Infarction 2 Participants. The New England journal of medicine. 1999; 341:217-25. [PubMed: 10413733]

137. Apple FS, Quist HE, Doyle PJ, Otto AP, Murakami MM. Plasma 99th percentile reference limits for cardiac troponin and creatine kinase MB mass for use with European Society of Cardiology/ 
American College of Cardiology consensus recommendations. Clin Chem. 2003; 49:1331-6. [PubMed: 12881449]

138. Daniels LB, Maisel AS. Cardiovascular biomarkers and sex: the case for women. Nature reviews Cardiology. 2015; 12:588-96. [PubMed: 26149486]

139. Shah AS, Griffiths M, Lee KK, McAllister DA, Hunter AL, Ferry AV, Cruikshank A, Reid A, Stoddart M, Strachan F, Walker S, Collinson PO, Apple FS, Gray AJ, Fox KA, Newby DE, Mills NL. High sensitivity cardiac troponin and the under-diagnosis of myocardial infarction in women: prospective cohort study. Bmj. 2015; 350:g7873. [PubMed: 25609052]

140. Granger CB, Goldberg RJ, Dabbous O, Pieper KS, Eagle KA, Cannon CP, Van De Werf F, Avezum A, Goodman SG, Flather MD, Fox KA. Predictors of hospital mortality in the global registry of acute coronary events. Archives of internal medicine. 2003; 163:2345-53. [PubMed: 14581255]

141. Berton G, Cordiano R, Cavuto F, Bagato F, Pellegrinet M, Cati A. Heart failure in women and men during acute coronary syndrome and long-term cardiovascular mortality (the ABC- $3 *$ Study on Heart Disease) (*Adria, Bassano, Conegliano, and Padova Hospitals). Int J Cardiol. 2016; 220:538-43. [PubMed: 27390984]

142. Anand SS, Xie CC, Mehta S, Franzosi MG, Joyner C, Chrolavicius S, Fox KA, Yusuf S. Differences in the management and prognosis of women and men who suffer from acute coronary syndromes. Journal of the American College of Cardiology. 2005; 46:1845-51. [PubMed: 16286169]

143. Gevaert SA, De Bacquer D, Evrard P, Convens C, Dubois P, Boland J, Renard M, Beauloye C, Coussement P, De Raedt H, de Meester A, Vandecasteele E, Vranckx P, Sinnaeve PR, Claeys MJ. Gender, TIMI risk score and in-hospital mortality in STEMI patients undergoing primary PCI: results from the Belgian STEMI registry. EuroIntervention. 2014; 9:1095-101. [PubMed: 24457280]

144. Agrawal S, Van Eyk J, Sobhani K, Wei J, Bairey Merz CN. Sex, Myocardial Infarction, and the Failure of Risk Scores in Women. J Womens Health (Larchmt). 2015; 24:859-61. [PubMed: 26288193]

145. de-Miguel-Balsa E, Latour-Perez J, Baeza-Roman A, Amoros-Verdu C, Fernandez-Lozano JA. GRACE Score Validation in Predicting Hospital Mortality: Analysis of the Role of Sex. J Womens Health (Larchmt). 2017

146. Bangalore S, Fonarow GC, Peterson ED, Hellkamp AS, Hernandez AF, Laskey W, Peacock WF, Cannon CP, Schwamm LH, Bhatt DL. Age and gender differences in quality of care and outcomes for patients with ST-segment elevation myocardial infarction. Am J Med. 2012; 125:1000-9. [PubMed: 22748404]

147. D’Onofrio G, Safdar B, Lichtman JH, Strait KM, Dreyer RP, Geda M, Spertus JA, Krumholz HM. Sex differences in reperfusion in young patients with ST-segment-elevation myocardial infarction: results from the VIRGO study. Circulation. 2015; 131:1324-32. [PubMed: 25792558]

148. Thygesen K, Alpert JS, Jaffe AS, Simoons ML, Chaitman BR, White HD, Katus HA, Apple FS, Lindahl B, Morrow DA, Clemmensen PM, Johanson P, Hod H, Underwood R, Bax JJ, Bonow JJ, Pinto F, Gibbons RJ, Fox KA, Atar D, Newby LK, Galvani M, Hamm CW, Uretsky BF, Steg PG, Wijns W, Bassand JP, Menasche P, Ravkilde J, Ohman EM, Antman EM, Wallentin LC, Armstrong PW, Januzzi JL, Nieminen MS, Gheorghiade M, Filippatos G, Luepker RV, Fortmann SP, Rosamond WD, Levy D, Wood D, Smith SC, Hu D, Lopez-Sendon JL, Robertson RM, Weaver D, Tendera M, Bove AA, Parkhomenko AN, Vasilieva EJ, Mendis S, Baumgartner H, Ceconi C, Dean V, Deaton C, Fagard R, Funck-Brentano C, Hasdai D, Hoes A, Kirchhof P, Knuuti J, Kolh P, McDonagh T, Moulin C, Popescu BA, Reiner Z, Sechtem U, Sirnes PA, Torbicki A, Vahanian A, Windecker S, Morais J, Aguiar C, Almahmeed W, Arnar DO, Barili F, Bloch KD, Bolger AF, Botker HE, Bozkurt B, Bugiardini R, Cannon C, de Lemos J, Eberli FR, Escobar E, Hlatky M, James S, Kern KB, Moliterno DJ, Mueller C, Neskovic AN, Pieske BM, Schulman SP, Storey RF, Taubert KA, Vranckx P, Wagner DR. Third universal definition of myocardial infarction. Journal of the American College of Cardiology. 2012; 60:1581-98. [PubMed: 22958960]

149. Spatz ES, Curry LA, Masoudi FA, Zhou S, Strait KM, Gross CP, Curtis JP, Lansky AJ, Soares Barreto-Filho JA, Lampropulos JF, Bueno H, Chaudhry SI, D’Onofrio G, Safdar B, Dreyer RP,

Front Neuroendocrinol. Author manuscript; available in PMC 2018 July 01. 
Murugiah K, Spertus JA, Krumholz HM. The Variation in Recovery: Role of Gender on Outcomes of Young AMI Patients (VIRGO) Classification System: A Taxonomy for Young Women With Acute Myocardial Infarction. Circulation. 2015; 132:1710-8. [PubMed: 26350057]

150. Bucholz EM, Strait KM, Dreyer RP, Lindau ST, D’Onofrio G, Geda M, Spatz ES, Beltrame JF, Lichtman JH, Lorenze NP, Bueno H, Krumholz HM. Sex differences in young patients with acute myocardial infarction: A VIRGO study analysis. Eur Heart J Acute Cardiovasc Care. 2016

151. Lee PY, Alexander KP, Hammill BG, Pasquali SK, Peterson ED. Representation of elderly persons and women in published randomized trials of acute coronary syndromes. Jama. 2001; 286:708-13. [PubMed: 11495621]

152. Sullivan AL, Beshansky JR, Ruthazer R, Murman DH, Mader TJ, Selker HP. Factors associated with longer time to treatment for patients with suspected acute coronary syndromes: a cohort study. Circulation Cardiovascular quality and outcomes. 2014; 7:86-94. [PubMed: 24425697]

153. Mosca L, Hammond G, Mochari-Greenberger H, Towfighi A, Albert MA, American Heart Association Cardiovascular D, Stroke in W, Special Populations Committee of the Council on Clinical Cardiology CoE and Prevention CoCNCoHB. Fifteen-year trends in awareness of heart disease in women: results of a 2012 American Heart Association national survey. Circulation. 2013; 127:1254-63. e1-29. [PubMed: 23429926]

154. McSweeney JC, Rosenfeld AG, Abel WM, Braun LT, Burke LE, Daugherty SL, Fletcher GF, Gulati M, Mehta LS, Pettey C, Reckelhoff JF, American Heart Association Council on C, Stroke Nursing CoCCCoE, Prevention CoHCoL, Cardiometabolic H, Council on Quality of C and Outcomes R. Preventing and Experiencing Ischemic Heart Disease as a Woman: State of the Science: A Scientific Statement From the American Heart Association. Circulation. 2016; 133:1302-31. [PubMed: 26927362]

155. Bairey Merz CN, Handberg EM, Shufelt CL, Mehta PK, Minissian MB, Wei J, Thomson LE, Berman DS, Shaw LJ, Petersen JW, Brown GH, Anderson RD, Shuster JJ, Cook-Wiens G, Rogatko A, Pepine CJ. A randomized, placebo-controlled trial of late Na current inhibition (ranolazine) in coronary microvascular dysfunction (CMD): impact on angina and myocardial perfusion reserve. Eur Heart J. 2016; 37:1504-13. [PubMed: 26614823]

156. O’Gara PT, Kushner FG, Ascheim DD, Casey DE Jr, Chung MK, de Lemos JA, Ettinger SM, Fang JC, Fesmire FM, Franklin BA, Granger CB, Krumholz HM, Linderbaum JA, Morrow DA, Newby LK, Ornato JP, Ou N, Radford MJ, Tamis-Holland JE, Tommaso CL, Tracy CM, Woo YJ, Zhao DX, Anderson JL, Jacobs AK, Halperin JL, Albert NM, Brindis RG, Creager MA, DeMets D, Guyton RA, Hochman JS, Kovacs RJ, Kushner FG, Ohman EM, Stevenson WG, Yancy CW, American College of Cardiology Foundation/American Heart Association Task Force on Practice G. 2013 ACCF/AHA guideline for the management of ST-elevation myocardial infarction: a report of the American College of Cardiology Foundation/American Heart Association Task Force on Practice Guidelines. Circulation. 2013; 127:e362-425. [PubMed: 23247304]

157. Tamis-Holland JE, Palazzo A, Stebbins AL, Slater JN, Boland J, Ellis SG, Hochman JS, Investigators GI-BAS. Benefits of direct angioplasty for women and men with acute myocardial infarction: results of the Global Use of Strategies to Open Occluded Arteries in Acute Coronary Syndromes Angioplasty (GUSTO II-B) Angioplasty Substudy. Am Heart J. 2004; 147:133-9. [PubMed: 14691431]

158. Amsterdam EA, Wenger NK, Brindis RG, Casey DE Jr, Ganiats TG, Holmes DR Jr, Jaffe AS, Jneid H, Kelly RF, Kontos MC, Levine GN, Liebson PR, Mukherjee D, Peterson ED, Sabatine MS, Smalling RW, Zieman SJ, American College of C, American Heart Association Task Force on Practice G, Society for Cardiovascular A, Interventions, Society of Thoracic S and American Association for Clinical C. 2014 AHA/ACC Guideline for the Management of Patients with NonST-Elevation Acute Coronary Syndromes: a report of the American College of Cardiology/ American Heart Association Task Force on Practice Guidelines. J Am Coll Cardiol. 2014; 64:e139-228. [PubMed: 25260718]

159. Bavry AA, Kumbhani DJ, Quiroz R, Ramchandani SR, Kenchaiah S, Antman EM. Invasive therapy along with glycoprotein IIb/IIIa inhibitors and intracoronary stents improves survival in non-ST-segment elevation acute coronary syndromes: a meta-analysis and review of the literature. Am J Cardiol. 2004; 93:830-5. [PubMed: 15050484] 
160. O’Donoghue M, Boden WE, Braunwald E, Cannon CP, Clayton TC, de Winter RJ, Fox KA, Lagerqvist B, McCullough PA, Murphy SA, Spacek R, Swahn E, Wallentin L, Windhausen F, Sabatine MS. Early invasive vs conservative treatment strategies in women and men with unstable angina and non-ST-segment elevation myocardial infarction: a meta-analysis. Jama. 2008; 300:71-80. [PubMed: 18594042]

161. Clayton TC, Pocock SJ, Henderson RA, Poole-Wilson PA, Shaw TR, Knight R, Fox KA. Do men benefit more than women from an interventional strategy in patients with unstable angina or nonST-elevation myocardial infarction? The impact of gender in the RITA 3 trial. Eur Heart J. 2004; 25:1641-50. [PubMed: 15351164]

162. Glaser R, Herrmann HC, Murphy SA, Demopoulos LA, DiBattiste PM, Cannon CP, Braunwald E. Benefit of an early invasive management strategy in women with acute coronary syndromes. Jama. 2002; 288:3124-9. [PubMed: 12495392]

163. Lagerqvist B, Safstrom K, Stahle E, Wallentin L, Swahn E, Investigators FISG. Is early invasive treatment of unstable coronary artery disease equally effective for both women and men? FRISC II Study Group Investigators. J Am Coll Cardiol. 2001; 38:41-8. [PubMed: 11451294]

164. Worrall-Carter L, McEvedy S, Wilson A, Rahman MA. Gender Differences in Presentation, Coronary Intervention, and Outcomes of 28,985 Acute Coronary Syndrome Patients in Victoria, Australia. Women's health issues : official publication of the Jacobs Institute of Women's Health. 2016; 26:14-20.

165. Tavris D, Shoaibi A, Chen AY, Uchida T, Roe MT, Chen J. Gender differences in the treatment of non-ST-segment elevation myocardial infarction. Clinical cardiology. 2010; 33:99-103. [PubMed: 20186991]

166. Blomkalns AL, Chen AY, Hochman JS, Peterson ED, Trynosky K, Diercks DB, Brogan GX Jr, Boden WE, Roe MT, Ohman EM, Gibler WB, Newby LK, Investigators C. Gender disparities in the diagnosis and treatment of non-ST-segment elevation acute coronary syndromes: large-scale observations from the CRUSADE (Can Rapid Risk Stratification of Unstable Angina Patients Suppress Adverse Outcomes With Early Implementation of the American College of Cardiology/ American Heart Association Guidelines) National Quality Improvement Initiative. J Am Coll Cardiol. 2005; 45:832-7. [PubMed: 15766815]

167. Ahmed B, Dauerman HL. Women, bleeding, and coronary intervention. Circulation. 2013; 127:641-9. [PubMed: 23381962]

168. Bertrand OF, Belisle P, Joyal D, Costerousse O, Rao SV, Jolly SS, Meerkin D, Joseph L. Comparison of transradial and femoral approaches for percutaneous coronary interventions: a systematic review and hierarchical Bayesian meta-analysis. Am Heart J. 2012; 163:632-48. [PubMed: 22520530]

169. Daugherty SL, Thompson LE, Kim S, Rao SV, Subherwal S, Tsai TT, Messenger JC, Masoudi FA. Patterns of use and comparative effectiveness of bleeding avoidance strategies in men and women following percutaneous coronary interventions: an observational study from the National Cardiovascular Data Registry. J Am Coll Cardiol. 2013; 61:2070-8. [PubMed: 23524046]

170. Yusuf S, Peto R, Lewis J, Collins R, Sleight P. Beta blockade during and after myocardial infarction: an overview of the randomized trials. Progress in cardiovascular diseases. 1985; 27:335-71. [PubMed: 2858114]

171. Bangalore S, Makani H, Radford M, Thakur K, Toklu B, Katz SD, DiNicolantonio JJ, Devereaux PJ, Alexander KP, Wetterslev J, Messerli FH. Clinical outcomes with beta-blockers for myocardial infarction: a meta-analysis of randomized trials. Am J Med. 2014; 127:939-53. [PubMed: 24927909]

172. Effect of ramipril on mortality and morbidity of survivors of acute myocardial infarction with clinical evidence of heart failure. The Acute Infarction Ramipril Efficacy (AIRE) Study Investigators. Lancet. 1993; 342:821-8. [PubMed: 8104270]

173. Pfeffer MA, Braunwald E, Moye LA, Basta L, Brown EJ Jr, Cuddy TE, Davis BR, Geltman EM, Goldman S, Flaker GC, et al. Effect of captopril on mortality and morbidity in patients with left ventricular dysfunction after myocardial infarction. Results of the survival and ventricular enlargement trial. The SAVE Investigators. The New England journal of medicine. 1992; 327:669-77. [PubMed: 1386652] 
174. Swedberg K, Held P, Kjekshus J, Rasmussen K, Ryden L, Wedel H. Effects of the early administration of enalapril on mortality in patients with acute myocardial infarction. Results of the Cooperative New Scandinavian Enalapril Survival Study II (CONSENSUS II). The New England journal of medicine. 1992; 327:678-84. [PubMed: 1495520]

175. Pfeffer MA, McMurray JJ, Velazquez EJ, Rouleau JL, Kober L, Maggioni AP, Solomon SD, Swedberg K, Van de Werf F, White H, Leimberger JD, Henis M, Edwards S, Zelenkofske S, Sellers MA, Califf RM, Valsartan in Acute Myocardial Infarction Trial I. Valsartan, captopril, or both in myocardial infarction complicated by heart failure, left ventricular dysfunction, or both. The New England journal of medicine. 2003; 349:1893-906. [PubMed: 14610160]

176. Flather MD, Yusuf S, Kober L, Pfeffer M, Hall A, Murray G, Torp-Pedersen C, Ball S, Pogue J, Moye L, Braunwald E. Long-term ACE-inhibitor therapy in patients with heart failure or leftventricular dysfunction: a systematic overview of data from individual patients. ACE-Inhibitor Myocardial Infarction Collaborative Group. Lancet. 2000; 355:1575-81. [PubMed: 10821360]

177. Garg R, Yusuf S. Overview of randomized trials of angiotensin-converting enzyme inhibitors on mortality and morbidity in patients with heart failure. Collaborative Group on ACE Inhibitor Trials. Jama. 1995; 273:1450-6. [PubMed: 7654275]

178. Cheung BM, Lauder IJ, Lau CP, Kumana CR. Meta-analysis of large randomized controlled trials to evaluate the impact of statins on cardiovascular outcomes. British journal of clinical pharmacology. 2004; 57:640-51. [PubMed: 15089818]

179. Gutierrez J, Ramirez G, Rundek T, Sacco RL. Statin therapy in the prevention of recurrent cardiovascular events: a sex-based meta-analysis. Arch Intern Med. 2012; 172:909-19. [PubMed: 22732744]

180. Hsue PY, Bittner VA, Betteridge J, Fayyad R, Laskey R, Wenger NK, Waters DD. Impact of female sex on lipid lowering, clinical outcomes, and adverse effects in atorvastatin trials. Am J Cardiol. 2015; 115:447-53. [PubMed: 25637322]

181. Collaborative overview of randomised trials of antiplatelet therapy-I: Prevention of death, myocardial infarction, and stroke by prolonged antiplatelet therapy in various categories of patients. Antiplatelet Trialists' Collaboration. Bmj. 1994; 308:81-106. [PubMed: 8298418]

182. Antithrombotic Trialists C. Baigent C, Blackwell L, Collins R, Emberson J, Godwin J, Peto R, Buring J, Hennekens C, Kearney P, Meade T, Patrono C, Roncaglioni MC, Zanchetti A. Aspirin in the primary and secondary prevention of vascular disease: collaborative meta-analysis of individual participant data from randomised trials. Lancet. 2009; 373:1849-60. [PubMed: 19482214]

183. Investigators C-O. Mehta SR, Bassand JP, Chrolavicius S, Diaz R, Eikelboom JW, Fox KA, Granger CB, Jolly S, Joyner CD, Rupprecht HJ, Widimsky P, Afzal R, Pogue J, Yusuf S. Dose comparisons of clopidogrel and aspirin in acute coronary syndromes. The New England journal of medicine. 2010; 363:930-42. [PubMed: 20818903]

184. Mehta SR, Yusuf S, Peters RJ, Bertrand ME, Lewis BS, Natarajan MK, Malmberg K, Rupprecht H, Zhao F, Chrolavicius S, Copland I, Fox KA, Clopidogrel in Unstable angina to prevent Recurrent Events trial I. Effects of pretreatment with clopidogrel and aspirin followed by longterm therapy in patients undergoing percutaneous coronary intervention: the PCI-CURE study. Lancet. 2001; 358:527-33. [PubMed: 11520521]

185. Boersma E, Harrington RA, Moliterno DJ, White H, Theroux P, Van de Werf F, de Torbal A, Armstrong PW, Wallentin LC, Wilcox RG, Simes J, Califf RM, Topol EJ, Simoons ML. Platelet glycoprotein IIb/IIIa inhibitors in acute coronary syndromes: a meta-analysis of all major randomised clinical trials. Lancet. 2002; 359:189-98. [PubMed: 11812552]

186. Hess CN, McCoy LA, Duggirala HJ, Tavris DR, O'Callaghan K, Douglas PS, Peterson ED, Wang TY. Sex-based differences in outcomes after percutaneous coronary intervention for acute myocardial infarction: a report from TRANSLATE-ACS. J Am Heart Assoc. 2014; 3:e00523. [PubMed: 24510115]

187. Subherwal S, Bach RG, Chen AY, Gage BF, Rao SV, Newby LK, Wang TY, Gibler WB, Ohman EM, Roe MT, Pollack CV Jr, Peterson ED, Alexander KP. Baseline risk of major bleeding in non-ST-segment-elevation myocardial infarction: the CRUSADE (Can Rapid risk stratification of Unstable angina patients Suppress ADverse outcomes with Early implementation of the ACC/AHA Guidelines) Bleeding Score. Circulation. 2009; 119:1873-82. [PubMed: 19332461] 
188. Akhter N, Milford-Beland S, Roe MT, Piana RN, Kao J, Shroff A. Gender differences among patients with acute coronary syndromes undergoing percutaneous coronary intervention in the American College of Cardiology-National Cardiovascular Data Registry (ACC-NCDR). Am Heart J. 2009; 157:141-8. [PubMed: 19081410]

189. Koopman C, Vaartjes I, Heintjes EM, Spiering W, van Dis I, Herings RM, Bots ML. Persisting gender differences and attenuating age differences in cardiovascular drug use for prevention and treatment of coronary heart disease, 1998-2010. Eur Heart J. 2013; 34:3198-205. [PubMed: 24046432]

190. Izadnegahdar M, Norris C, Kaul P, Pilote L, Humphries KH. Basis for sex-dependent outcomes in acute coronary syndrome. The Canadian journal of cardiology. 2014; 30:713-20. [PubMed: 24468419]

191. Izadnegahdar M, Singer J, Lee MK, Gao M, Thompson CR, Kopec J, Humphries KH. Do younger women fare worse? Sex differences in acute myocardial infarction hospitalization and early mortality rates over ten years. J Womens Health (Larchmt). 2014; 23:10-7. [PubMed: 24206026]

192. Leung Yinko SS, Pelletier R, Behlouli H, Norris CM, Humphries KH, Pilote L, investigators G-P. Health-related quality of life in premature acute coronary syndrome: does patient sex or gender really matter? J Am Heart Assoc. 2014; 3

193. Pelletier R, Khan NA, Cox J, Daskalopoulou SS, Eisenberg MJ, Bacon SL, Lavoie KL, Daskupta K, Rabi D, Humphries KH, Norris CM, Thanassoulis G, Behlouli H, Pilote L, Investigators G-P. Sex Versus Gender-Related Characteristics: Which Predicts Outcome After Acute Coronary Syndrome in the Young? J Am Coll Cardiol. 2016; 67:127-35. [PubMed: 26791057]

194. Berger JS, Elliott L, Gallup D, Roe M, Granger CB, Armstrong PW, Simes RJ, White HD, Van de Werf F, Topol EJ, Hochman JS, Newby LK, Harrington RA, Califf RM, Becker RC, Douglas PS. Sex differences in mortality following acute coronary syndromes. Jama. 2009; 302:874-82. [PubMed: 19706861]

195. Reynolds HR, Farkouh ME, Lincoff AM, Hsu A, Swahn E, Sadowski ZP, White JA, Topol EJ, Hochman JS, Investigators GV. Impact of female sex on death and bleeding after fibrinolytic treatment of myocardial infarction in GUSTO V. Arch Intern Med. 2007; 167:2054-60. [PubMed: 17954798]

196. Mehta RH, Stebbins AS, Lopes RD, Califf RM, Pieper KS, Armstrong PW, Van de Werf F, Hochman JS, White HD, Topol EJ, Alexander JH, Granger CB. Comparison of incidence of bleeding and mortality of men versus women with ST-elevation myocardial infarction treated with fibrinolysis. Am J Cardiol. 2012; 109:320-6. [PubMed: 22078221]

197. Singh M, Rihal CS, Gersh BJ, Roger VL, Bell MR, Lennon RJ, Lerman A, Holmes DR Jr. Mortality differences between men and women after percutaneous coronary interventions. A 25year, single-center experience. J Am Coll Cardiol. 2008; 51:2313-20. [PubMed: 18549915]

198. Humphries KH, Gao M, Pu A, Lichtenstein S, Thompson CR. Significant improvement in shortterm mortality in women undergoing coronary artery bypass surgery (1991 to 2004). J Am Coll Cardiol. 2007; 49:1552-8. [PubMed: 17418294]

199. Regitz-Zagrosek V, Lehmkuhl E, Hocher B, Goesmann D, Lehmkuhl HB, Hausmann H, Hetzer R. Gender as a risk factor in young, not in old, women undergoing coronary artery bypass grafting. J Am Coll Cardiol. 2004; 44:2413-4. [PubMed: 15607409]

200. Kendel F, Gelbrich G, Wirtz M, Lehmkuhl E, Knoll N, Hetzer R, Regitz-Zagrosek V. Predictive relationship between depression and physical functioning after coronary surgery. Arch Intern Med. 2010; 170:1717-21. [PubMed: 20975017]

201. Vaccarino V, Lin ZQ, Kasl SV, Mattera JA, Roumanis SA, Abramson JL, Krumholz HM. Gender differences in recovery after coronary artery bypass surgery. J Am Coll Cardiol. 2003; 41:30714. [PubMed: 12535827]

202. Saw J. Spontaneous coronary artery dissection. The Canadian journal of cardiology. 2013; 29:1027-33. [PubMed: 23498840]

203. Vrints CJ. Spontaneous coronary artery dissection. Heart. 2010; 96:801-8. [PubMed: 20448134]

Front Neuroendocrinol. Author manuscript; available in PMC 2018 July 01. 
204. Poon K, Bell B, Raffel OC, Walters DL, Jang IK. Spontaneous coronary artery dissection: utility of intravascular ultrasound and optical coherence tomography during percutaneous coronary intervention. Circulation Cardiovascular interventions. 2011; 4:e5-7. [PubMed: 21505162]

205. Saw J, Poulter R, Fung A, Wood D, Hamburger J, Buller CE. Spontaneous coronary artery dissection in patients with fibromuscular dysplasia. A case series. Circulation Cardiovascular interventions. 2012; 5:134-7. [PubMed: 22338003]

206. Tweet MS, Hayes SN, Pitta SR, Simari RD, Lerman A, Lennon RJ, Gersh BJ, Khambatta S, Best PJ, Rihal CS, Gulati R. Clinical Features, Management and Prognosis of Spontaneous Coronary Artery Dissection. Circulation. 2012; 126:579-88. [PubMed: 22800851]

207. Alfonso F, Paulo M, Gonzalo N, Dutary J, Jimenez-Quevedo P, Lennie V, Escaned J, Banuelos C, Hernandez R, Macaya C. Diagnosis of spontaneous coronary artery dissection by optical coherence tomography. J Am Coll Cardiol. 2012; 59:1073-9. [PubMed: 22421300]

208. Alfonso F, Bastante T, Rivero F, Cuesta J, Benedicto A, Saw J, Gulati R. Spontaneous coronary artery dissection. Circulation journal : official journal of the Japanese Circulation Society. 2014; 78:2099-110. [PubMed: 25131524]

209. Tweet MS, Eleid MF, Best PJ, Lennon RJ, Lerman A, Rihal CS, Holmes DR Jr, Hayes SN, Gulati R. Spontaneous coronary artery dissection: revascularization versus conservative therapy. Circulation Cardiovascular interventions. 2014; 7:777-86. [PubMed: 25406203]

210. Lettieri C, Zavalloni D, Rossini R, Morici N, Ettori F, Leonzi O, Latib A, Ferlini M, Trabattoni D, Colombo P, Galli M, Tarantini G, Napodano M, Piccaluga E, Passamonti E, Sganzerla P, Ielasi A, Coccato M, Martinoni A, Musumeci G, Zanini R, Castiglioni B. Management and Long-Term Prognosis of Spontaneous Coronary Artery Dissection. Am J Cardiol. 2015; 116:66-73. [PubMed: 25937347]

211. Rogowski S, Maeder MT, Weilenmann D, Haager PK, Ammann P, Rohner F, Joerg L, Rickli H. Spontaneous Coronary Artery Dissection: Angiographic Follow-Up and Long-Term Clinical Outcome in a Predominantly Medically Treated Population. Catheterization and cardiovascular interventions : official journal of the Society for Cardiac Angiography \& Interventions. 2015

212. Rashid HN, Wong DT, Wijesekera H, Gutman SJ, Shanmugam VB, Gulati R, Malaipan Y, Meredith IT, Psaltis PJ. Incidence and characterisation of spontaneous coronary artery dissection as a cause of acute coronary syndrome -A single-centre Australian experience. Int J Cardiol. 2016; 202:336-8. [PubMed: 26426273]

213. Roura G, Ariza-Sole A, Rodriguez-Caballero IF, Gomez-Lara J, Ferreiro JL, Romaguera R, Teruel L, de Albert M, Gomez-Hospital JA, Cequier A. Noninvasive Follow-Up of Patients With Spontaneous Coronary Artery Dissection With CT Angiography. JACC Cardiovascular imaging. 2015

214. Nakashima T, Noguchi T, Haruta S, Yamamoto Y, Oshima S, Nakao K, Taniguchi Y, Yamaguchi J, Tsuchihashi K, Seki A, Kawasaki T, Uchida T, Omura N, Kikuchi M, Kimura K, Ogawa H, Miyazaki S, Yasuda S. Prognostic impact of spontaneous coronary artery dissection in young female patients with acute myocardial infarction: A report from the Angina Pectoris-Myocardial Infarction Multicenter Investigators in Japan. Int J Cardiol. 2016; 207:341-348. [PubMed: 26820364]

215. Nishiguchi T, Tanaka A, Ozaki Y, Taruya A, Fukuda S, Taguchi H, Iwaguro T, Ueno S, Okumoto Y, Akasaka T. Prevalence of spontaneous coronary artery dissection in patients with acute coronary syndrome. Eur Heart J Acute Cardiovasc Care. 2013

216. Hill SF, Sheppard MN. Non-atherosclerotic coronary artery disease associated with sudden cardiac death. Heart. 2010; 96:1119-25. [PubMed: 20511306]

217. Saw J, Aymong E, Mancini J, Sedlak T, Starovoytov A, Ricci D. Non-atherosclerotic coronary artery disease in young women. The Canadian journal of cardiology. 2014; 30:814-9. [PubMed: 24726091]

218. Maehara A, Mintz GS, Castagna MT, Pichard AD, Satler LF, Waksman R, Suddath WO, Kent $\mathrm{KM}$, Weissman NJ. Intravascular ultrasound assessment of spontaneous coronary artery dissection. Am J Cardiol. 2002; 89:466-8. [PubMed: 11835932]

219. Saw J, Ricci D, Starovoytov A, Fox R, Buller CE. Spontaneous coronary artery dissection: prevalence of predisposing conditions including fibromuscular dysplasia in a tertiary center cohort. JACC Cardiovasc Interv. 2013; 6:44-52. [PubMed: 23266235] 
220. Prasad M, Tweet MS, Hayes SN, Leng S, Liang JJ, Eleid MF, Gulati R, Vrtiska TJ. Prevalence of extracoronary vascular abnormalities and fibromuscular dysplasia in patients with spontaneous coronary artery dissection. Am J Cardiol. 2015; 115:1672-7. [PubMed: 25929580]

221. Saw J. Coronary angiogram classification of spontaneous coronary artery dissection. Catheterization and cardiovascular interventions : official journal of the Society for Cardiac Angiography \& Interventions. 2014; 84:1115-22. [PubMed: 24227590]

222. Yip A, Saw J. Spontaneous coronary artery dissection-A review. Cardiovascular diagnosis and therapy. 2015; 5:37-48. [PubMed: 25774346]

223. Nienaber CA, Powell JT. Management of acute aortic syndromes. Eur Heart J. 2012; 33:26-35b. [PubMed: 21810861]

224. Saw J, Mancini GB, Humphries KH. Contemporary Review on Spontaneous Coronary Artery Dissection. J Am Coll Cardiol. 2016; 68:297-312. [PubMed: 27417009]

225. Shamloo BK, Chintala RS, Nasur A, Ghazvini M, Shariat P, Diggs JA, Singh SN. Spontaneous coronary artery dissection: aggressive vs. conservative therapy. J Invasive Cardiol. 2010; 22:2228. [PubMed: 20440039]

226. Zupan I, Noc M, Trinkaus D, Popovic M. Double vessel extension of spontaneous left main coronary artery dissection in young women treated with thrombolytics. Catheterization and cardiovascular interventions : official journal of the Society for Cardiac Angiography \& Interventions. 2001; 2001:226-30.

227. Anderson JL, Adams CD, Antman EM, Bridges CR, Califf RM, Casey DE Jr, Chavey WE 2nd, Fesmire FM, Hochman JS, Levin TN, Lincoff AM, Peterson ED, Theroux P, Wenger NK, Wright RS, Smith SC Jr, Jacobs AK, Halperin JL, Hunt SA, Krumholz HM, Kushner FG, Lytle BW, Nishimura R, Ornato JP, Page RL, Riegel B. ACC/AHA 2007 guidelines for the management of patients with unstable angina/non-ST-Elevation myocardial infarction: a report of the American College of Cardiology/American Heart Association Task Force on Practice Guidelines (Writing Committee to Revise the 2002 Guidelines for the Management of Patients With Unstable Angina/ Non-ST-Elevation Myocardial Infarction) developed in collaboration with the American College of Emergency Physicians, the Society for Cardiovascular Angiography and Interventions, and the Society of Thoracic Surgeons endorsed by the American Association of Cardiovascular and Pulmonary Rehabilitation and the Society for Academic Emergency Medicine. J Am Coll Cardiol. 2007; 50:e1-e157. [PubMed: 17692738]

228. Chou AY, Prakash R, Rajala J, Birnie T, Isserow S, Taylor CM, Ignaszewski A, Chan S, Starovoytov A, Saw J. The First Dedicated Cardiac Rehabilitation Program for Patients with Spontaneous Coronary Artery Dissection: Description and Initial Results. The Canadian journal of cardiology. 2016; 32:554-60. [PubMed: 26923234]

229. Saw J, Aymong E, Sedlak T, Buller CE, Starovoytov A, Ricci D, Robinson S, Vuurmans T, Gao M, Humphries K, Mancini GB. Spontaneous coronary artery dissection: association with predisposing arteriopathies and precipitating stressors and cardiovascular outcomes. Circulation Cardiovascular interventions. 2014; 7:645-55. [PubMed: 25294399]

230. Lyon AR, Bossone E, Schneider B, Sechtem U, Citro R, Underwood SR, Sheppard MN, Figtree GA, Parodi G, Akashi YJ, Ruschitzka F, Filippatos G, Mebazaa A, Omerovic E. Current state of knowledge on Takotsubo syndrome: a Position Statement from the Taskforce on Takotsubo Syndrome of the Heart Failure Association of the European Society of Cardiology. European journal of heart failure. 2016; 18:8-27.

231. Akashi YJ, Ishihara M. Takotsubo Syndrome: Insights from Japan. Heart failure clinics. 2016; 12:587-95. [PubMed: 27638028]

232. Hemingway H, Langenberg C, Damant J, Frost C, Pyorala K, Barrett-Connor E. Prevalence of angina in women versus men: a systematic review and meta-analysis of international variations across 31 countries. Circulation. 2008; 117:1526-36. [PubMed: 18347213]

233. National Institutes of Health NH L, and Blood Institute. Morbidity and Mortality Chart Book. 2012. Retrieved from https://www.nhlbi.nih.gov/research/reports/2012-mortality-chart-book

234. Sedlak TL, Lee M, Izadnegahdar M, Merz CN, Gao M, Humphries KH. Sex differences in clinical outcomes in patients with stable angina and no obstructive coronary artery disease. Am Heart J. 2013; 166:38-44. [PubMed: 23816019] 
235. Humphries KH, Pu A, Gao M, Carere RG, Pilote L. Angina with "normal" coronary arteries: sex differences in outcomes. American heart journal. 2008; 155:375-81. [PubMed: 18215611]

236. Hemingway H, McCallum A, Shipley M, Manderbacka K, Martikainen P, Keskimaki I. Incidence and prognostic implications of stable angina pectoris among women and men. Jama. 2006; 295:1404-11. [PubMed: 16551712]

237. Johnston N, Schenck-Gustafsson K, Lagerqvist B. Are we using cardiovascular medications and coronary angiography appropriately in men and women with chest pain? Eur Heart J. 2011; 32:1331-6. [PubMed: 21317147]

238. Bullock-Palmer RP. Prevention, Detection and Management of Coronary Artery Disease in Minority Females. Ethn Dis. 2015; 25:499-506. [PubMed: 26674268]

239. Davis KB, Chaitman B, Ryan T, Bittner V, Kennedy JW. Comparison of 15-year survival for men and women after initial medical or surgical treatment for coronary artery disease: a CASS registry study. Coronary Artery Surgery Study. J Am Coll Cardiol. 1995; 25:1000-9. [PubMed: 7897108]

240. Shaw LJ, Shaw RE, Merz CN, Brindis RG, Klein LW, Nallamothu B, Douglas PS, Krone RJ, McKay CR, Block PC, Hewitt K, Weintraub WS, Peterson ED, American College of CardiologyNational Cardiovascular Data Registry I. Impact of ethnicity and gender differences on angiographic coronary artery disease prevalence and in-hospital mortality in the American College of Cardiology-National Cardiovascular Data Registry. Circulation. 2008; 117:1787-801. [PubMed: 18378615]

241. Shaw LJ, Bairey Merz CN, Pepine CJ, Reis SE, Bittner V, Kelsey SF, Olson M, Johnson BD, Mankad S, Sharaf BL, Rogers WJ, Wessel TR, Arant CB, Pohost GM, Lerman A, Quyyumi AA, Sopko G, Investigators W. Insights from the NHLBI-Sponsored Women's Ischemia Syndrome Evaluation (WISE) Study: Part I: gender differences in traditional and novel risk factors, symptom evaluation, and gender-optimized diagnostic strategies. J Am Coll Cardiol. 2006; 47:S4-S20. [PubMed: 16458170]

242. Wenger NK. Angina in women. Curr Cardiol Rep. 2010; 12:307-14. [PubMed: 20425162]

243. Task Force M. Montalescot G, Sechtem U, Achenbach S, Andreotti F, Arden C, Budaj A, Bugiardini R, Crea F, Cuisset T, Di Mario C, Ferreira JR, Gersh BJ, Gitt AK, Hulot JS, Marx N, Opie LH, Pfisterer M, Prescott E, Ruschitzka F, Sabate M, Senior R, Taggart DP, van der Wall EE, Vrints CJ, Guidelines ESCCfP, Zamorano JL, Achenbach S, Baumgartner H, Bax JJ, Bueno H, Dean V, Deaton C, Erol C, Fagard R, Ferrari R, Hasdai D, Hoes AW, Kirchhof P, Knuuti J, Kolh P, Lancellotti P, Linhart A, Nihoyannopoulos P, Piepoli MF, Ponikowski P, Sirnes PA, Tamargo JL, Tendera M, Torbicki A, Wijns W, Windecker S, Document R, Knuuti J, Valgimigli M, Bueno H, Claeys MJ, Donner-Banzhoff N, Erol C, Frank H, Funck-Brentano C, Gaemperli O, Gonzalez-Juanatey JR, Hamilos M, Hasdai D, Husted S, James SK, Kervinen K, Kolh P, Kristensen SD, Lancellotti P, Maggioni AP, Piepoli MF, Pries AR, Romeo F, Ryden L, Simoons ML, Sirnes PA, Steg PG, Timmis A, Wijns W, Windecker S, Yildirir A, Zamorano JL. 2013 ESC guidelines on the management of stable coronary artery disease: the Task Force on the management of stable coronary artery disease of the European Society of Cardiology. Eur Heart J. 2013; 34:2949-3003. [PubMed: 23996286]

244. Diamond GA, Forrester JS. Analysis of probability as an aid in the clinical diagnosis of coronaryartery disease. The New England journal of medicine. 1979; 300:1350-8. [PubMed: 440357]

245. Piepoli MF, Hoes AW, Agewall S, Albus C, Brotons C, Catapano AL, Cooney MT, Corra U, Cosyns B, Deaton C, Graham I, Hall MS, Richard Hobbs FD, Lochen ML, Lollgen H, MarquesVidal P, Perk J, Prescott E, Redon J, Richter DJ, Sattar N, Smulders Y, Tiberi M, Bart van der Worp H, van Dis I, Monique Verschuren WM. 2016 European Guidelines on cardiovascular disease prevention in clinical practice. Rev Esp Cardiol (Engl Ed). 2016; 69:939. [PubMed: 27692125]

246. Ridker PM, Buring JE, Rifai N, Cook NR. Development and validation of improved algorithms for the assessment of global cardiovascular risk in women: the Reynolds Risk Score. Jama. 2007; 297:611-9. [PubMed: 17299196]

247. Mieres JH, Gulati M, Bairey Merz N, Berman DS, Gerber TC, Hayes SN, Kramer CM, Min JK, Newby LK, Nixon JV, Srichai MB, Pellikka PA, Redberg RF, Wenger NK, Shaw LJ. Role of noninvasive testing in the clinical evaluation of women with suspected ischemic heart disease: a

Front Neuroendocrinol. Author manuscript; available in PMC 2018 July 01. 
consensus statement from the American Heart Association. Circulation. 2014; 130:350-79. [PubMed: 25047587]

248. Shaw LJ, Mieres JH, Hendel RH, Boden WE, Gulati M, Veledar E, Hachamovitch R, Arrighi JA, Merz CN, Gibbons RJ, Wenger NK, Heller GV. Comparative effectiveness of exercise electrocardiography with or without myocardial perfusion single photon emission computed tomography in women with suspected coronary artery disease: results from the What Is the Optimal Method for Ischemia Evaluation in Women (WOMEN) trial. Circulation. 2011; 124:1239-49. [PubMed: 21844080]

249. Alexander KP, Shaw LJ, Shaw LK, Delong ER, Mark DB, Peterson ED. Value of exercise treadmill testing in women. Journal of the American College of Cardiology. 1998; 32:1657-64. [PubMed: 9822093]

250. Shaw LJ, Peterson ED, Shaw LK, Kesler KL, DeLong ER, Harrell FE Jr, Muhlbaier LH, Mark DB. Use of a prognostic treadmill score in identifying diagnostic coronary disease subgroups. Circulation. 1998; 98:1622-30. [PubMed: 9778327]

251. Douglas PS, Hoffmann U, Patel MR, Mark DB, Al-Khalidi HR, Cavanaugh B, Cole J, Dolor RJ, Fordyce CB, Huang M, Khan MA, Kosinski AS, Krucoff MW, Malhotra V, Picard MH, Udelson JE, Velazquez EJ, Yow E, Cooper LS, Lee KL. Outcomes of anatomical versus functional testing for coronary artery disease. The New England journal of medicine. 2015; 372:1291-300. [PubMed: 25773919]

252. Hemal K, Pagidipati NJ, Coles A, Dolor RJ, Mark DB, Pellikka PA, Hoffmann U, Litwin SE, Daubert MA, Shah SH, Ariani K, Bullock-Palmer RP, Martinez B, Lee KL, Douglas PS. Sex Differences in Demographics, Risk Factors, Presentation, and Noninvasive Testing in Stable Outpatients With Suspected Coronary Artery Disease: Insights From the PROMISE Trial. JACC Cardiovascular imaging. 2016; 9:337-46. [PubMed: 27017234]

253. Pena JM, Min JK. Coronary artery disease: Sex-related differences in CAD and plaque characteristics. Nature reviews Cardiology. 2016; 13:318-9.

254. Gulati M, Cooper-DeHoff RM, McClure C, Johnson BD, Shaw LJ, Handberg EM, Zineh I, Kelsey SF, Arnsdorf MF, Black HR, Pepine CJ, Merz CN. Adverse cardiovascular outcomes in women with nonobstructive coronary artery disease: a report from the Women's Ischemia Syndrome Evaluation Study and the St James Women Take Heart Project. Archives of internal medicine. 2009; 169:843-50. [PubMed: 19433695]

255. Daly C, Clemens F, Lopez Sendon JL, Tavazzi L, Boersma E, Danchin N, Delahaye F, Gitt A, Julian D, Mulcahy D, Ruzyllo W, Thygesen K, Verheugt F, Fox KM, Euro Heart Survey I. Gender differences in the management and clinical outcome of stable angina. Circulation. 2006; 113:490-8. [PubMed: 16449728]

256. Kunadian V, Qiu W, Lagerqvist B, Johnston N, Sinclair H, Tan Y, Ludman P, James S, Sarno G, National Institute for Cardiovascular Outcomes R, Swedish Coronary A and Angioplasty R. Gender Differences in Outcomes and Predictors of All-Cause Mortality After Percutaneous Coronary Intervention (Data from United Kingdom and Sweden). Am J Cardiol. 2017; 119:210 216. [PubMed: 27816119]

257. Maddox TM, Stanislawski MA, Grunwald GK, Bradley SM, Ho PM, Tsai TT, Patel MR, Sandhu A, Valle J, Magid DJ, Leon B, Bhatt DL, Fihn SD, Rumsfeld JS. Nonobstructive coronary artery disease and risk of myocardial infarction. Jama. 2014; 312:1754-63. [PubMed: 25369489]

258. Sharaf B, Wood T, Shaw L, Johnson BD, Kelsey S, Anderson RD, Pepine CJ, Bairey Merz CN. Adverse outcomes among women presenting with signs and symptoms of ischemia and no obstructive coronary artery disease: findings from the National Heart, Lung, and Blood Institutesponsored Women's Ischemia Syndrome Evaluation (WISE) angiographic core laboratory. American heart journal. 2013; 166:134-41. [PubMed: 23816032]

259. Jespersen L, Hvelplund A, Abildstrom SZ, Pedersen F, Galatius S, Madsen JK, Jorgensen E, Kelbaek H, Prescott E. Stable angina pectoris with no obstructive coronary artery disease is associated with increased risks of major adverse cardiovascular events. Eur Heart J. 2012; 33:734-44. [PubMed: 21911339]

260. Pauly DF, Johnson BD, Anderson RD, Handberg EM, Smith KM, Cooper-DeHoff RM, Sopko G, Sharaf BM, Kelsey SF, Merz CN, Pepine CJ. In women with symptoms of cardiac ischemia, nonobstructive coronary arteries, and microvascular dysfunction, angiotensin-converting enzyme 
inhibition is associated with improved microvascular function: A double-blind randomized study from the National Heart, Lung and Blood Institute Women's Ischemia Syndrome Evaluation (WISE). Am Heart J. 2011; 162:678-84. [PubMed: 21982660]

261. Ong P, Athanasiadis A, Borgulya G, Mahrholdt H, Kaski JC, Sechtem U. High prevalence of a pathological response to acetylcholine testing in patients with stable angina pectoris and unobstructed coronary arteries. The ACOVA Study (Abnormal COronary VAsomotion in patients with stable angina and unobstructed coronary arteries). J Am Coll Cardiol. 2012; 59:655-62. [PubMed: 22322081]

262. Cannon RO 3rd, Epstein SE. "Microvascular angina" as a cause of chest pain with angiographically normal coronary arteries. Am J Cardiol. 1988; 61:1338-43. [PubMed: 3287885]

263. Opherk D, Zebe H, Weihe E, Mall G, Durr C, Gravert B, Mehmel HC, Schwarz F, Kubler W. Reduced coronary dilatory capacity and ultrastructural changes of the myocardium in patients with angina pectoris but normal coronary arteriograms. Circulation. 1981; 63:817-25. [PubMed: 7471337]

264. Noel Bairey Merz C, Eteiba W, Pepine C, ohnson BD, Shaw L, Kelsey S. Cardiac syndrome X: Relation to microvascular angina and other conditions. Current Cardiovascular Risk Reports. 2007; 1:167-175.

265. Cox ID, Botker HE, Bagger JP, Sonne HS, Kristensen BO, Kaski JC. Elevated endothelin concentrations are associated with reduced coronary vasomotor responses in patients with chest pain and normal coronary arteriograms. Journal of the American College of Cardiology. 1999; 34:455-60. [PubMed: 10440159]

266. Piatti P, Fragasso G, Monti LD, Caumo A, Van Phan C, Valsecchi G, Costa S, Fochesato E, Pozza G, Pontiroli AE, Chierchia S. Endothelial and metabolic characteristics of patients with angina and angiographically normal coronary arteries: comparison with subjects with insulin resistance syndrome and normal controls. J Am Coll Cardiol. 1999; 34:1452-60. [PubMed: 10551692]

267. Piatti P, Fragasso G, Monti LD, Setola E, Lucotti P, Fermo I, Paroni R, Galluccio E, Pozza G, Chierchia S, Margonato A. Acute intravenous L-arginine infusion decreases endothelin-1 levels and improves endothelial function in patients with angina pectoris and normal coronary arteriograms: correlation with asymmetric dimethylarginine levels. Circulation. 2003; 107:42936. [PubMed: 12551867]

268. Camici PG, Gistri R, Lorenzoni R, Sorace O, Michelassi C, Bongiorni MG, Salvadori PA, L'Abbate A. Coronary reserve and exercise ECG in patients with chest pain and normal coronary angiograms. Circulation. 1992; 86:179-86. [PubMed: 1617771]

269. Nihoyannopoulos P, Kaski JC, Crake T, Maseri A. Absence of myocardial dysfunction during stress in patients with syndrome X. J Am Coll Cardiol. 1991; 18:1463-70. [PubMed: 1939947]

270. Schindler TH, Schelbert HR, Quercioli A, Dilsizian V. Cardiac PET imaging for the detection and monitoring of coronary artery disease and microvascular health. JACC Cardiovascular imaging. 2010; 3:623-40. [PubMed: 20541718]

271. Pepine CJ, Anderson RD, Sharaf BL, Reis SE, Smith KM, Handberg EM, Johnson BD, Sopko G, Bairey Merz CN. Coronary microvascular reactivity to adenosine predicts adverse outcome in women evaluated for suspected ischemia results from the National Heart, Lung and Blood Institute WISE (Women's Ischemia Syndrome Evaluation) study. J Am Coll Cardiol. 2010; 55:2825-32. [PubMed: 20579539]

272. von Mering GO, Arant CB, Wessel TR, McGorray SP, Bairey Merz CN, Sharaf BL, Smith KM, Olson MB, Johnson BD, Sopko G, Handberg E, Pepine CJ, Kerensky RA, National Heart L and Blood I. Abnormal coronary vasomotion as a prognostic indicator of cardiovascular events in women: results from the National Heart, Lung, and Blood Institute-Sponsored Women's Ischemia Syndrome Evaluation (WISE). Circulation. 2004; 109:722-5. [PubMed: 14970106]

273. Rossini R, Capodanno D, Lettieri C, Musumeci G, Limbruno U, Molfese M, Spatari V, Calabria P, Romano M, Tarantini G, Gavazzi A, Angiolillo DJ. Long-term outcomes of patients with acute coronary syndrome and nonobstructive coronary artery disease. Am J Cardiol. 2013; 112:150-5. [PubMed: 23602693]

274. Asbury EA, Kanji N, Ernst E, Barbir M, Collins P. Autogenic training to manage symptomology in women with chest pain and normal coronary arteries. Menopause. 2009; 16:60-5. [PubMed: 18978640] 
275. Lanza GA, Colonna G, Pasceri V, Maseri A. Atenolol versus amlodipine versus isosorbide-5mononitrate on anginal symptoms in syndrome X. Am J Cardiol. 1999; 84:854-6, A8. [PubMed: 10513787]

276. Kayikcioglu M, Payzin S, Yavuzgil O, Kultursay H, Can LH, Soydan I. Benefits of statin treatment in cardiac syndrome-X1. Eur Heart J. 2003; 24:1999-2005. [PubMed: 14613735]

277. Pizzi C, Manfrini O, Fontana F, Bugiardini R. Angiotensin-converting enzyme inhibitors and 3hydroxy-3-methylglutaryl coenzyme A reductase in cardiac Syndrome X: role of superoxide dismutase activity. Circulation. 2004; 109:53-8. [PubMed: 14699004]

278. Tiefenbacher CP, Friedrich S, Bleeke T, Vahl C, Chen X, Niroomand F. ACE inhibitors and statins acutely improve endothelial dysfunction of human coronary arterioles. Am J Physiol Heart Circ Physiol. 2004; 286:H1425-32. [PubMed: 14644762]

279. Villano A, Di Franco A, Nerla R, Sestito A, Tarzia P, Lamendola P, Di Monaco A, Sarullo FM, Lanza GA, Crea F. Effects of ivabradine and ranolazine in patients with microvascular angina pectoris. Am J Cardiol. 2013; 112:8-13. [PubMed: 23558043]

280. Denardo SJ, Wen X, Handberg EM, Bairey Merz CN, Sopko GS, Cooper-Dehoff RM, Pepine CJ. Effect of phosphodiesterase type 5 inhibition on microvascular coronary dysfunction in women: a Women's Ischemia Syndrome Evaluation (WISE) ancillary study. Clinical cardiology. 2011; 34:483-7. [PubMed: 21780138]

281. Cannon RO 3rd, Quyyumi AA, Mincemoyer R, Stine AM, Gracely RH, Smith WB, Geraci MF, Black BC, Uhde TW, Waclawiw MA, et al. Imipramine in patients with chest pain despite normal coronary angiograms. The New England journal of medicine. 1994; 330:1411-7. [PubMed: 8159194]

282. Lerman A, Burnett JC Jr, Higano ST, McKinley LJ, Holmes DR Jr. Long-term L-arginine supplementation improves small-vessel coronary endothelial function in humans. Circulation. 1998; 97:2123-8. [PubMed: 9626172]

283. Frampton J, Buckley MM, Fitton A. Nicorandil. A review of its pharmacology and therapeutic efficacy in angina pectoris. Drugs. 1992; 44:625-55. [PubMed: 1281076]

284. Tardif JC, Ford I, Tendera M, Bourassa MG, Fox K. Efficacy of ivabradine, a new selective I(f) inhibitor, compared with atenolol in patients with chronic stable angina. Eur Heart J. 2005; 26:2529-36. [PubMed: 16214830]

285. Kemp HG Jr. Left ventricular function in patients with the anginal syndrome and normal coronary arteriograms. Am J Cardiol. 1973; 32:375-6. [PubMed: 4725594]

286. Lichtlen PR, Bargheer K, Wenzlaff P. Long-term prognosis of patients with anginalike chest pain and normal coronary angiographic findings. Journal of the American College of Cardiology. 1995; 25:1013-8. [PubMed: 7897110]

287. Shaw LJ, Merz CN, Pepine CJ, Reis SE, Bittner V, Kip KE, Kelsey SF, Olson M, Johnson BD, Mankad S, Sharaf BL, Rogers WJ, Pohost GM, Sopko G, Women's Ischemia Syndrome Evaluation I. The economic burden of angina in women with suspected ischemic heart disease: results from the National Institutes of Health-National Heart, Lung, and Blood Institutesponsored Women's Ischemia Syndrome Evaluation. Circulation. 2006; 114:894-904. [PubMed: 16923752]

288. Ponikowski P, Voors AA, Anker SD, Bueno H, Cleland JG, Coats AJ, Falk V, Gonzalez-Juanatey JR, Harjola VP, Jankowska EA, Jessup M, Linde C, Nihoyannopoulos P, Parissis JT, Pieske B, Riley JP, Rosano GM, Ruilope LM, Ruschitzka F, Rutten FH, van der Meer P. 2016 ESC Guidelines for the Diagnosis and Treatment of Acute and Chronic Heart Failure. Rev Esp Cardiol (Engl Ed). 2016; 69:1167. [PubMed: 27894487]

289. McMurray JJ, Petrie MC, Murdoch DR, Davie AP. Clinical epidemiology of heart failure: public and private health burden. Eur Heart J. 1998; 19(Suppl P):P9-16. [PubMed: 9886707]

290. Roger VL. Epidemiology of heart failure. Circ Res. 2013; 113:646-59. [PubMed: 23989710]

291. Barker WH, Mullooly JP, Getchell W. Changing incidence and survival for heart failure in a welldefined older population, 1970-1974 and 1990-1994. Circulation. 2006; 113:799-805. [PubMed: 16461823]

292. Mozaffarian D, Benjamin EJ, Go AS, Arnett DK, Blaha MJ, Cushman M, de Ferranti S, Despres JP, Fullerton HJ, Howard VJ, Huffman MD, Judd SE, Kissela BM, Lackland DT, Lichtman JH, 
Lisabeth LD, Liu S, Mackey RH, Matchar DB, McGuire DK, Mohler ER 3rd, Moy CS, Muntner P, Mussolino ME, Nasir K, Neumar RW, Nichol G, Palaniappan L, Pandey DK, Reeves MJ, Rodriguez CJ, Sorlie PD, Stein J, Towfighi A, Turan TN, Virani SS, Willey JZ, Woo D, Yeh RW, Turner MB, American Heart Association Statistics C and Stroke Statistics S. Heart disease and stroke statistics-2015 update: a report from the American Heart Association. Circulation. 2015; 131:e29-322. [PubMed: 25520374]

293. Curtis LH, Whellan DJ, Hammill BG, Hernandez AF, Anstrom KJ, Shea AM, Schulman KA. Incidence and prevalence of heart failure in elderly persons, 1994-2003. Arch Intern Med. 2008; 168:418-24. [PubMed: 18299498]

294. Gerber Y, Weston SA, Redfield MM, Chamberlain AM, Manemann SM, Jiang R, Killian JM, Roger VL. A contemporary appraisal of the heart failure epidemic in Olmsted County, Minnesota, 2000 to 2010. JAMA Intern Med. 2015; 175:996-1004. [PubMed: 25895156]

295. Bleumink GS, Knetsch AM, Sturkenboom MC, Straus SM, Hofman A, Deckers JW, Witteman JC, Stricker BH. Quantifying the heart failure epidemic: prevalence, incidence rate, lifetime risk and prognosis of heart failure The Rotterdam Study. Eur Heart J. 2004; 25:1614-9. [PubMed: 15351160]

296. Eaton CB, Pettinger M, Rossouw J, Martin LW, Foraker R, Quddus A, Liu S, Wampler NS, Hank Wu WC, Manson JE, Margolis K, Johnson KC, Allison M, Corbie-Smith G, Rosamond W, Breathett K, Klein L. Risk Factors for Incident Hospitalized Heart Failure With Preserved Versus Reduced Ejection Fraction in a Multiracial Cohort of Postmenopausal Women. Circ Heart Fail. 2016; 9

297. Dunlay SM, Weston SA, Jacobsen SJ, Roger VL. Risk factors for heart failure: a populationbased case-control study. Am J Med. 2009; 122:1023-8. [PubMed: 19854330]

298. Lam CS, Carson PE, Anand IS, Rector TS, Kuskowski M, Komajda M, McKelvie RS, McMurray JJ, Zile MR, Massie BM, Kitzman DW. Sex differences in clinical characteristics and outcomes in elderly patients with heart failure and preserved ejection fraction: the Irbesartan in Heart Failure with Preserved Ejection Fraction (I-PRESERVE) trial. Circ Heart Fail. 2012; 5:571-8. [PubMed: 22887722]

299. Lee DS, Gona P, Vasan RS, Larson MG, Benjamin EJ, Wang TJ, Tu JV, Levy D. Relation of disease pathogenesis and risk factors to heart failure with preserved or reduced ejection fraction: insights from the framingham heart study of the national heart, lung, and blood institute. Circulation. 2009; 119:3070-7. [PubMed: 19506115]

300. Ware JS, Seidman JG, Arany Z. Shared Genetic Predisposition in Peripartum and Dilated Cardiomyopathies. The New England journal of medicine. 2016; 374:2601-2.

301. Arany Z, Elkayam U. Peripartum Cardiomyopathy. Circulation. 2016; 133:1397-409. [PubMed: 27045128]

302. Suter TM, Ewer MS. Cancer drugs and the heart: importance and management. Eur Heart J. 2013; 34:1102-11. [PubMed: 22789916]

303. Zagar TM, Cardinale DM, Marks LB. Breast cancer therapy-associated cardiovascular disease. Nat Rev Clin Oncol. 2016; 13:172-84. [PubMed: 26598943]

304. Bowles EJ, Wellman R, Feigelson HS, Onitilo AA, Freedman AN, Delate T, Allen LA, Nekhlyudov L, Goddard KA, Davis RL, Habel LA, Yood MU, McCarty C, Magid DJ, Wagner EH, Pharmacovigilance Study T. Risk of heart failure in breast cancer patients after anthracycline and trastuzumab treatment: a retrospective cohort study. J Natl Cancer Inst. 2012; 104:1293-305. [PubMed: 22949432]

305. Group EUCCS. Regitz-Zagrosek V, Oertelt-Prigione S, Prescott E, Franconi F, Gerdts E, ForystLudwig A, Maas AH, Kautzky-Willer A, Knappe-Wegner D, Kintscher U, Ladwig KH, SchenckGustafsson K, Stangl V. Gender in cardiovascular diseases: impact on clinical manifestations, management, and outcomes. Eur Heart J. 2016; 37:24-34. [PubMed: 26530104]

306. Ouyang P, Wenger NK, Taylor D, Rich-Edwards JW, Steiner M, Shaw LJ, Berga SL, Miller VM, Merz NB. Strategies and methods to study female-specific cardiovascular health and disease: a guide for clinical scientists. Biol Sex Differ. 2016; 7:19. [PubMed: 27034774]

307. Petrov G, Dworatzek E, Schulze TM, Dandel M, Kararigas G, Mahmoodzadeh S, Knosalla C, Hetzer R, Regitz-Zagrosek V. Maladaptive remodeling is associated with impaired survival in 
women but not in men after aortic valve replacement. JACC Cardiovascular imaging. 2014; 7:1073-80. [PubMed: 25306541]

308. Shekelle PG, Rich MW, Morton SC, Atkinson CS, Tu W, Maglione M, Rhodes S, Barrett M, Fonarow GC, Greenberg B, Heidenreich PA, Knabel T, Konstam MA, Steimle A, Warner Stevenson L. Efficacy of angiotensin-converting enzyme inhibitors and beta-blockers in the management of left ventricular systolic dysfunction according to race, gender, and diabetic status: a meta-analysis of major clinical trials. J Am Coll Cardiol. 2003; 41:1529-38. [PubMed: 12742294]

309. Adams KF Jr, Patterson JH, Gattis WA, O'Connor CM, Lee CR, Schwartz TA, Gheorghiade M. Relationship of serum digoxin concentration to mortality and morbidity in women in the digitalis investigation group trial: a retrospective analysis. J Am Coll Cardiol. 2005; 46:497-504. [PubMed: 16053964]

310. Zusterzeel R, Spatz ES, Curtis JP, Sanders WE, Selzman KA, Pina IL, Bao H, Ponirakis A, Varosy PD, Masoudi FA, Canos DA, Strauss DG. Cardiac resynchronization therapy in women versus men: observational comparative effectiveness study from the National Cardiovascular Data Registry. Circulation Cardiovascular quality and outcomes. 2015; 8:S4-11. [PubMed: 25714821]

311. Zusterzeel R, Selzman KA, Sanders WE, Canos DA, O’Callaghan KM, Carpenter JL, Pina IL, Strauss DG. Cardiac resynchronization therapy in women: US Food and Drug Administration meta-analysis of patient-level data. JAMA Intern Med. 2014; 174:1340-8. [PubMed: 25090172]

312. Clinical Investigation on Differences in the Magnitude of CRT Response in WOmen Versus MEN (BIOWOMEN). 2015. Retrieved from https://clinicaltrials.gov/ct2/show/NCT02344420.

313. Sliwa K, Blauwet L, Tibazarwa K, Libhaber E, Smedema JP, Becker A, McMurray J, Yamac H, Labidi S, Struman I, Hilfiker-Kleiner D. Evaluation of bromocriptine in the treatment of acute severe peripartum cardiomyopathy: a proof-of-concept pilot study. Circulation. 2010; 121:146573. [PubMed: 20308616]

314. Effect of Bromocriptine on Left Ventricular Function in Women With Peripartum Cardiomyopathy (PPCM). Retrieved from https://clinicaltrials.gov/ct2/show/study/ NCT00998556 Accessed on January 2017

315. Bergstrom A, Andersson B, Edner M, Nylander E, Persson H, Dahlstrom U. Effect of carvedilol on diastolic function in patients with diastolic heart failure and preserved systolic function. Results of the Swedish Doppler-echocardiographic study (SWEDIC). European journal of heart failure. 2004; 6:453-61. [PubMed: 15182771]

316. Hernandez AF, Hammill BG, O’Connor CM, Schulman KA, Curtis LH, Fonarow GC. Clinical effectiveness of beta-blockers in heart failure: findings from the OPTIMIZE-HF (Organized Program to Initiate Lifesaving Treatment in Hospitalized Patients with Heart Failure) Registry. J Am Coll Cardiol. 2009; 53:184-92. [PubMed: 19130987]

317. Cleland JG, Tendera M, Adamus J, Freemantle N, Polonski L, Taylor J, Investigators P-C. The perindopril in elderly people with chronic heart failure (PEP-CHF) study. Eur Heart J. 2006; 27:2338-45. [PubMed: 16963472]

318. Pitt B, Pfeffer MA, Assmann SF, Boineau R, Anand IS, Claggett B, Clausell N, Desai AS, Diaz R, Fleg JL, Gordeev I, Harty B, Heitner JF, Kenwood CT, Lewis EF, O’Meara E, Probstfield JL, Shaburishvili T, Shah SJ, Solomon SD, Sweitzer NK, Yang S, McKinlay SM, Investigators T. Spironolactone for heart failure with preserved ejection fraction. The New England journal of medicine. 2014; 370:1383-92. [PubMed: 24716680]

319. Regitz-Zagrosek V, Petrov G, Lehmkuhl E, Smits JM, Babitsch B, Brunhuber C, Jurmann B, Stein J, Schubert C, Merz NB, Lehmkuhl HB, Hetzer R. Heart transplantation in women with dilated cardiomyopathy. Transplantation. 2010; 89:236-44. [PubMed: 20098289]

320. Kannel WB, D'Agostino RB, Wilson PW, Belanger AJ, Gagnon DR. Diabetes, fibrinogen, and risk of cardiovascular disease: the Framingham experience. Am Heart J. 1990; 120:672-6. [PubMed: 2389702] 


\section{Highlights}

- Cardiovascular disease is the major cause of death in women worldwide

- Women under-represented in clinical trials and results often not reported by sex

- Women and men share most risk factors, but several are unique to women

- Coronary microvascular dysfunction may be present if no obstructive lesions found

- Women are more likely to have heart failure with preserved ejection fraction. 


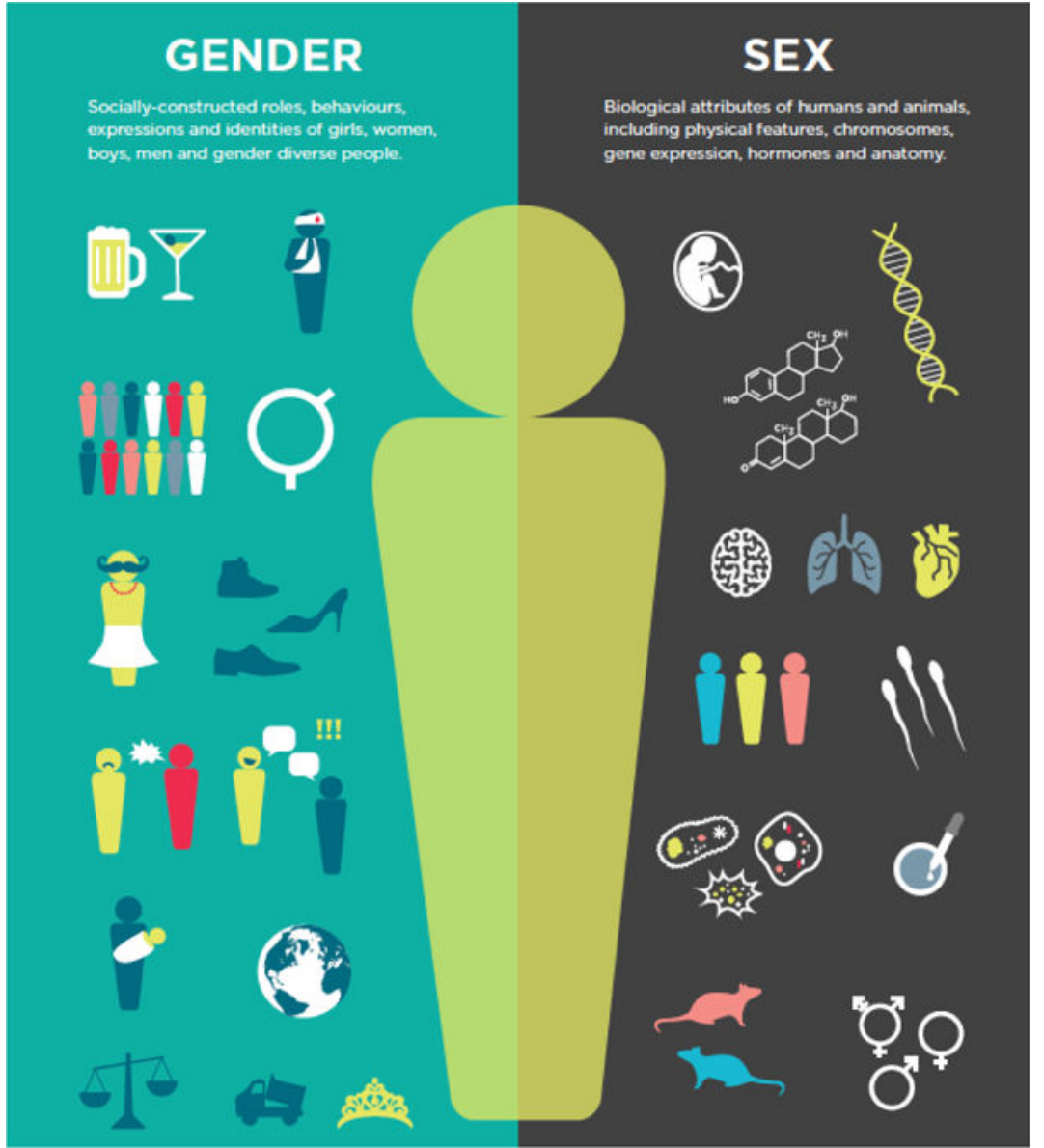

Figure 1.

Infographic of Sex and Gender from Canadian Institutes of Health Research 


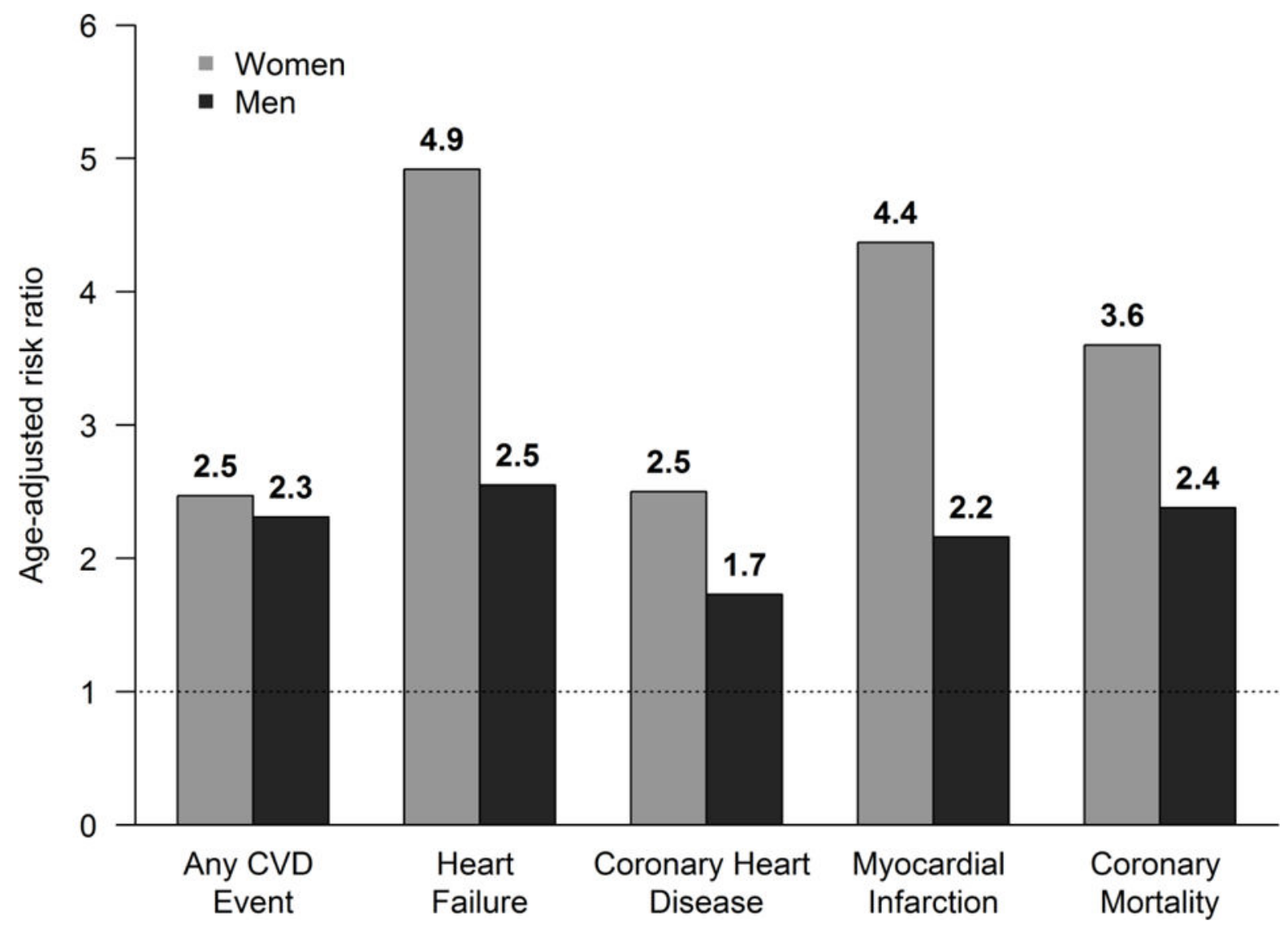

Figure 2. Relative risk of cardiovascular events in men and women with diabetes Note: Adapted from Kannel et $\mathrm{al}^{320}$, with permission. 


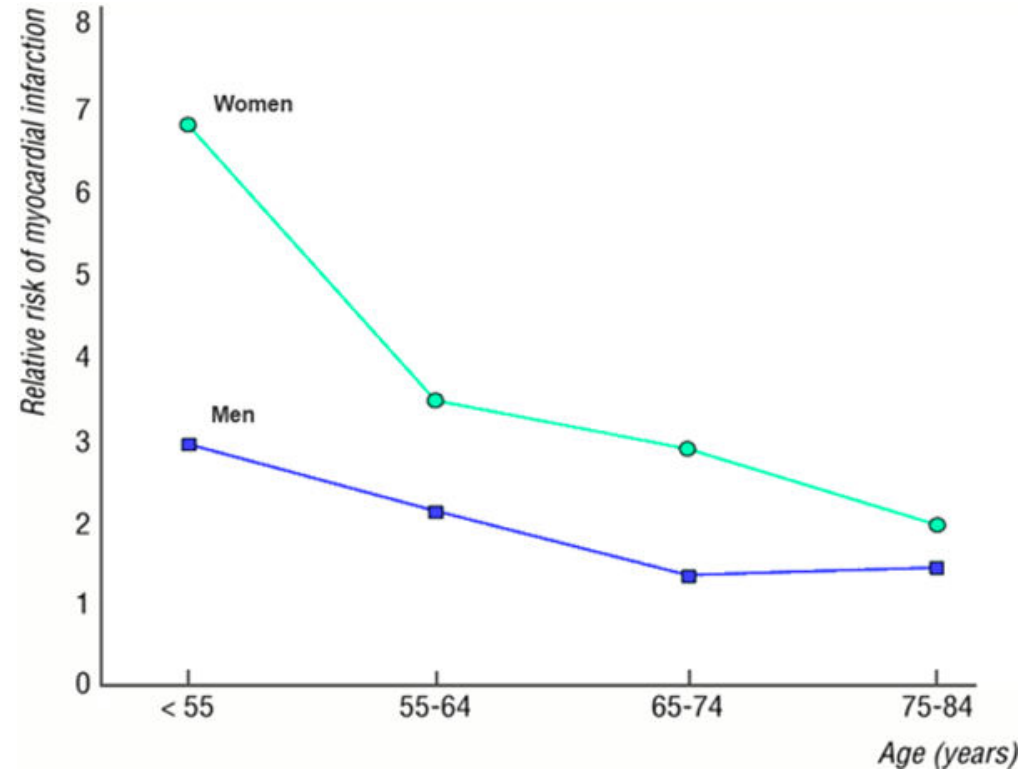

Figure 3. Relative risk of myocardial infarction for current smokers compared with never smokers

Note: Adapted from Prescott et $\mathrm{al}^{28}$, with permission. 
Thrombus formation on a ruptured or eroded plaque

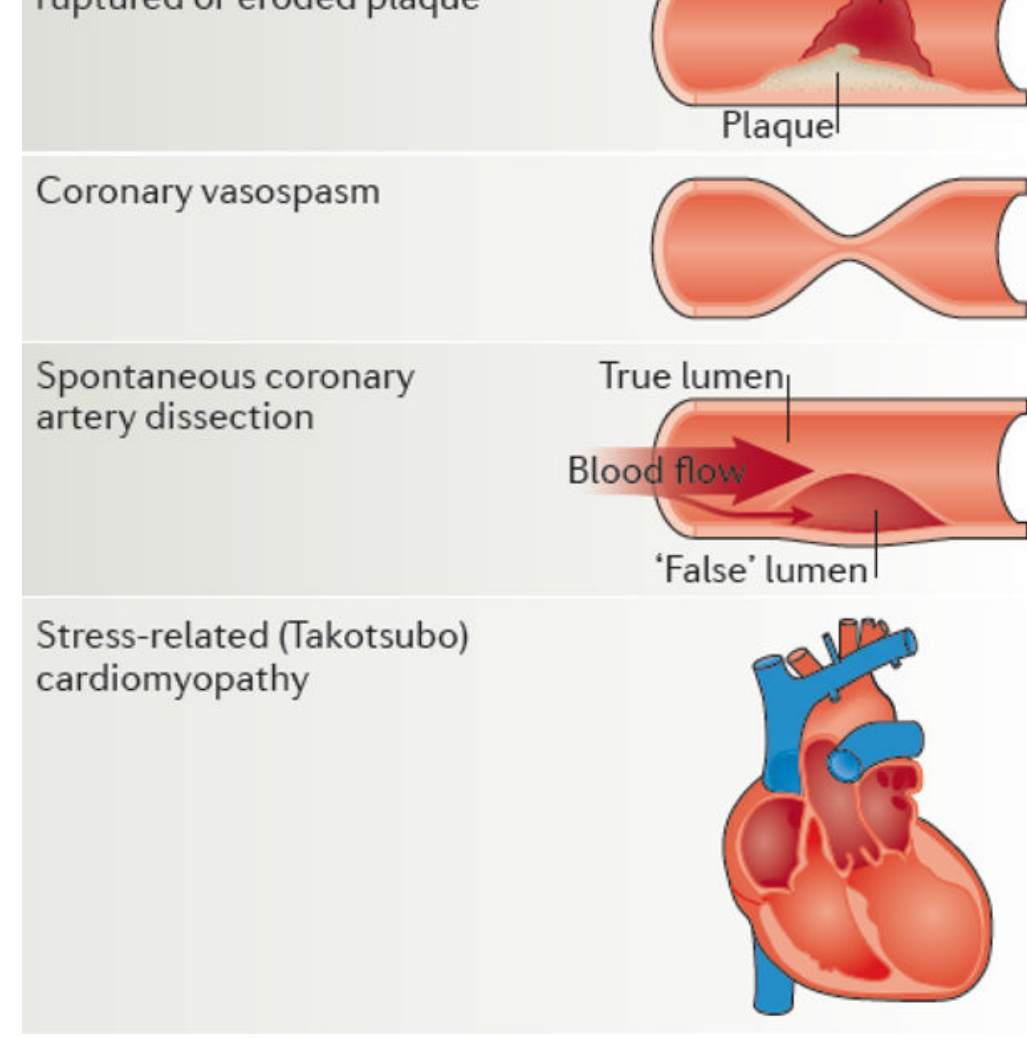

Figure 4. Sex-specific differences in the pathophysiology of acute coronary syndrome Note: Although Coronary vasospasm, spontaneous coronary artery dissection (SCAD) and stress-related (Takotsubo) cardiomyopathy do occur in both males and females, these presentations are much more common among females. With respect to thrombus formation, males are more likely to present with ruptured plaque while females are more likely to present with eroded plaques. Adapted from Pagidipati et al ${ }^{124}$., with permission 


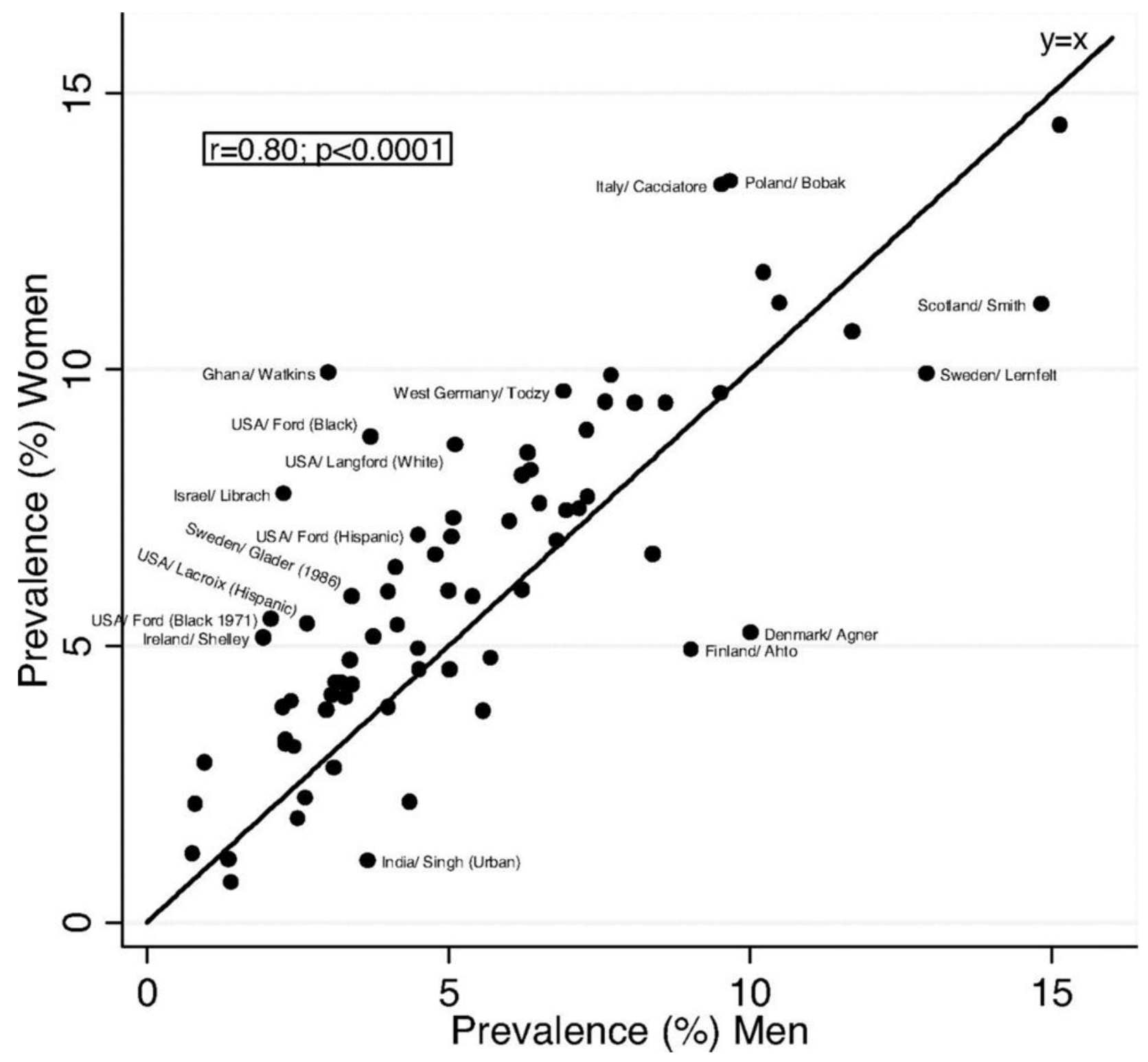

Figure 5. Angina prevalence in women vs men

Note: Adapted from Hemingway et $\mathrm{al}^{232}$, with permission 


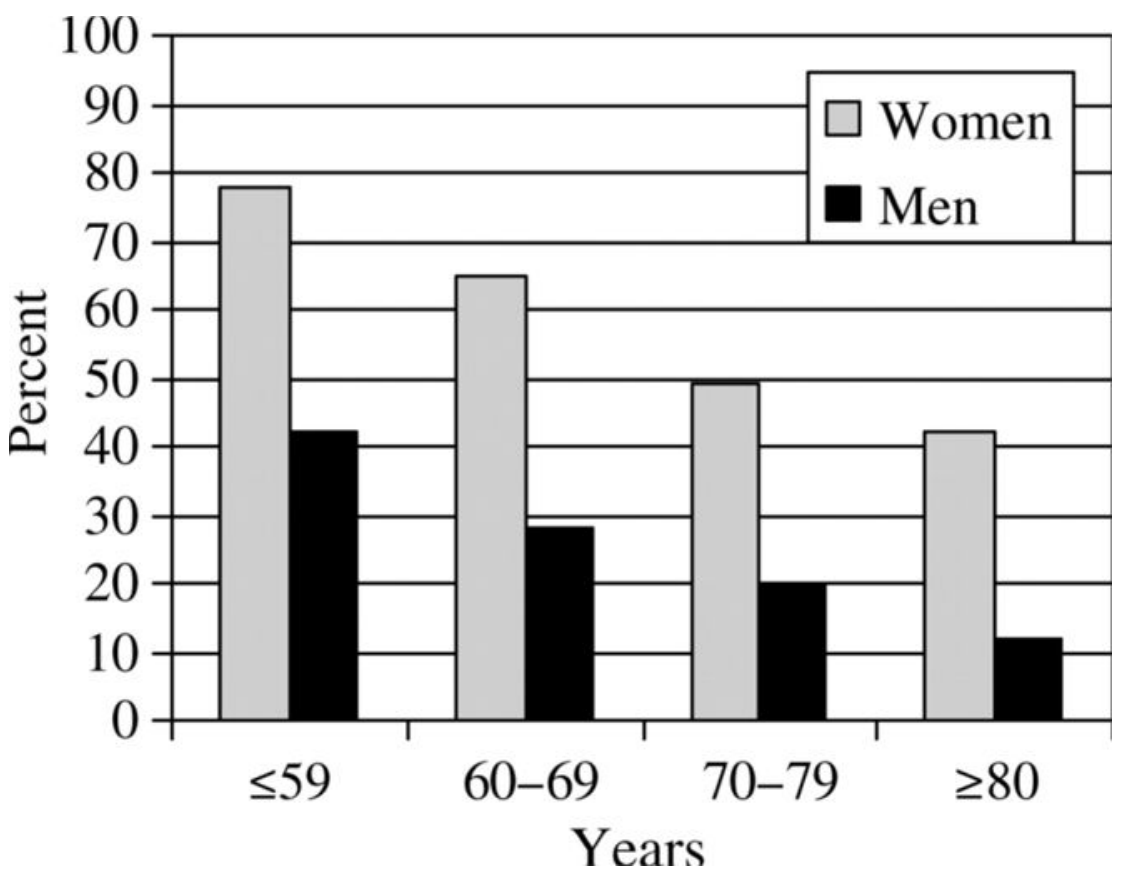

Figure 6. Proportion of patients $(\%)$ with normal findings at coronary angiography according to sex and age group

Note: Adapted from Johnston et $\mathrm{al}^{237}$, with permission. 


\section{Symptomatic Women with Suspected IHD}

\section{Index IHD Risk Estimate}

Intermediate IHD Risk

No Resting ST Segment Abnormalities
Intermediate-High IHD Risk

Resting ST Segment Abnormalities or Functional Disability

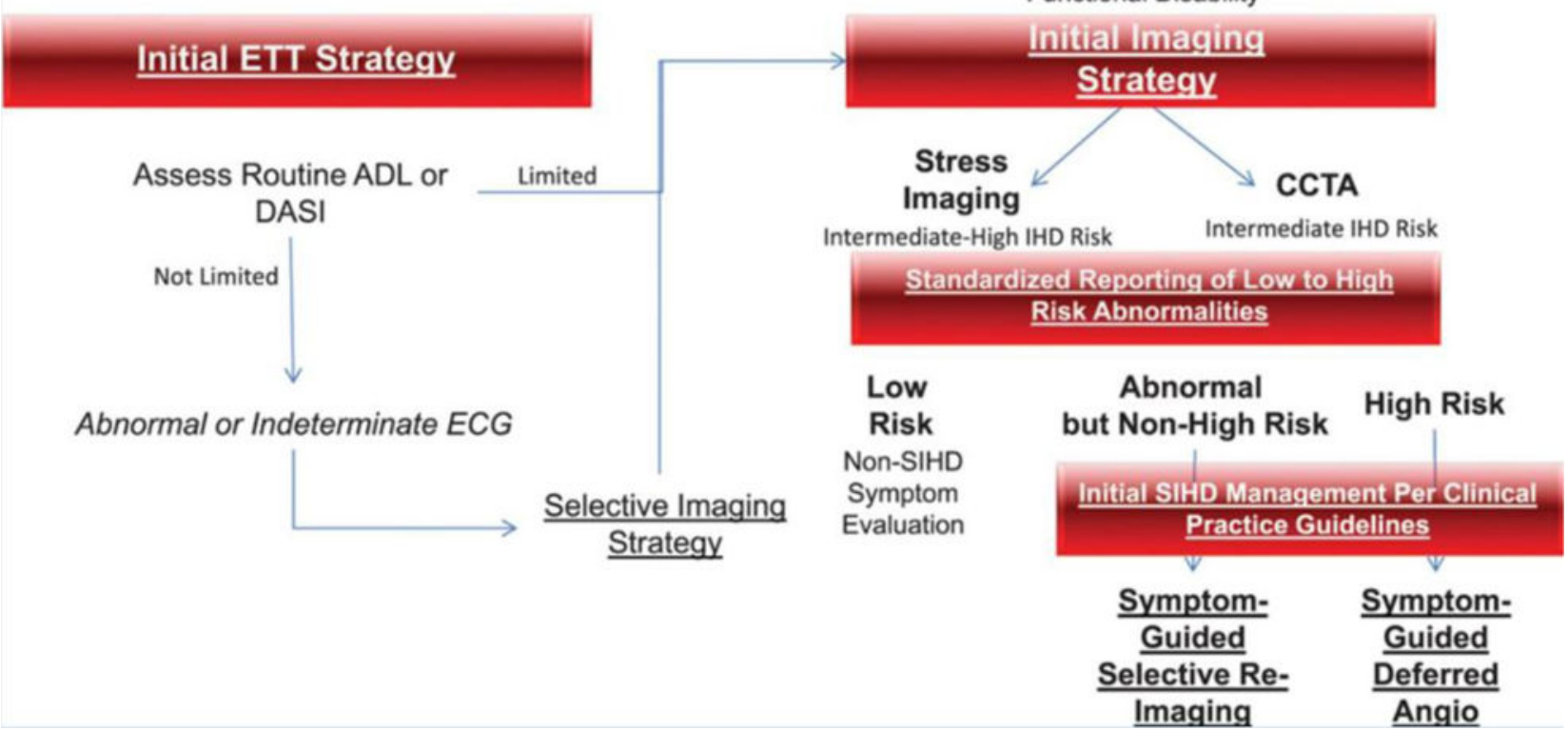

Figure 7. Diagnostic evaluation algorithm for symptomatic women with suspected ischemic heart disease and intermediate and intermediate-high risk

Note: ADL, activities of daily living; Angio, angiography; CCTA, coronary computed tomography angiography; DASI, Duke Activity Status Index; ETT, exercise treadmill testing; and SIHD, stable ischemic heart disease. Adapted from Mieres JH et $\mathrm{al}^{247}$, with permission. 


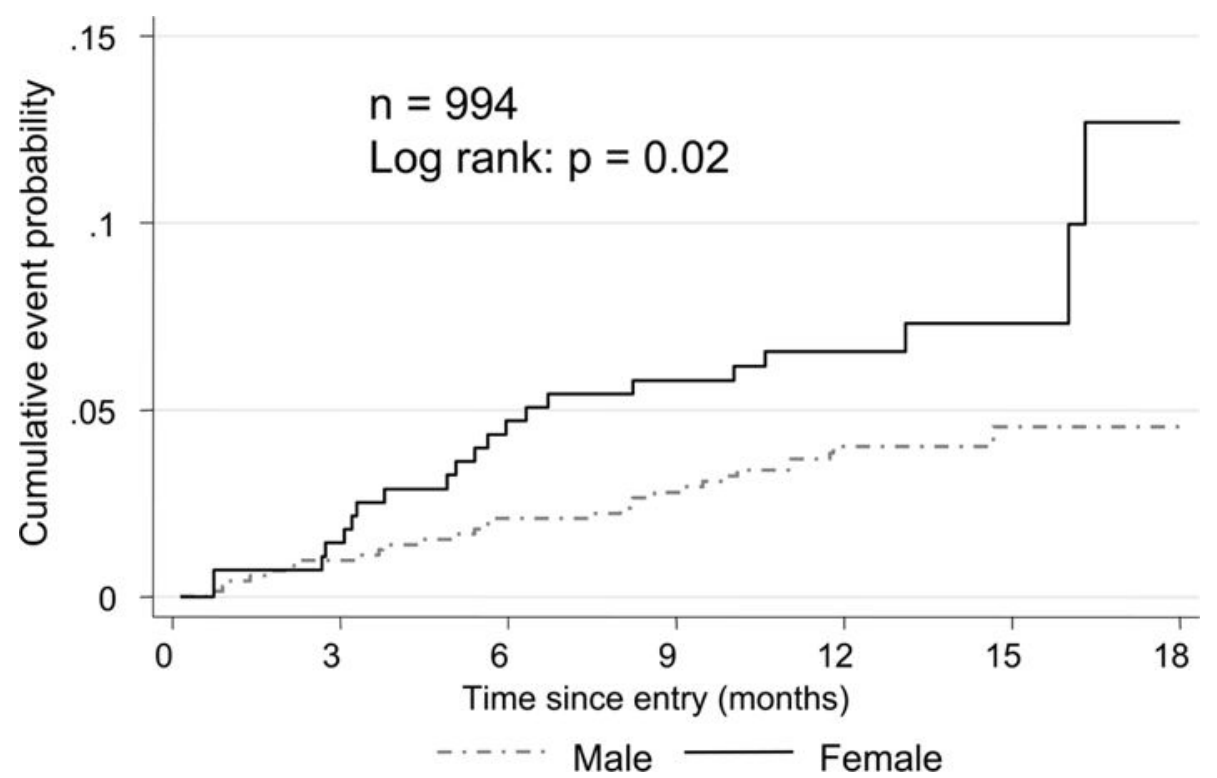

Figure 8. Cumulative probability of death or MI in patients with confirmed coronary disease and stable angina according to Sex

Note: Adapted from Daly et $\mathrm{al}^{255}$, with permission 


\section{CENTRAL ILLUSTRATION Management Algorithm for Spontaneous Coronary Artery Dissection}

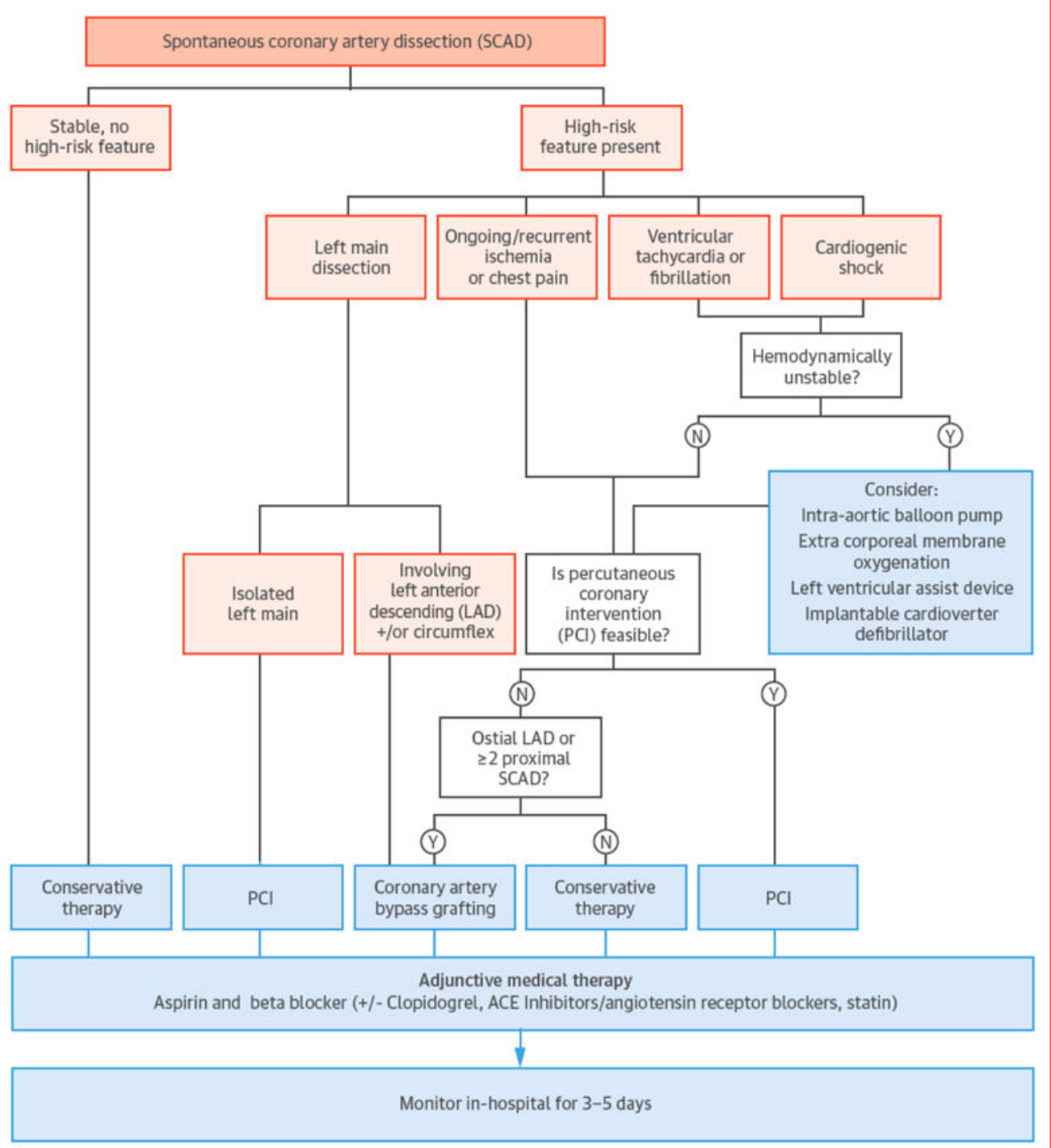

Figure 9. Management of Algorithm for spontaneous coronary artery dissection Note: Adapted from Saw et $\mathrm{al}^{224}$, with permission 